\title{
PENGARUH PENERAPAN ELECTRONIC PROCUREMENT DAN GOOD GOVERNANCE TERHADAP KINERJA PENGADAAN BARANG/JASA PADA BAGIAN PENGADAAN BARANG DAN JASA SEKRETARIAT DAERAH KABUPATEN PANDEGLANG
}

\section{TESIS}

Diajukan Untuk Melengkapi Persyaratan Guna Memperoleh Gelar Magister Administrasi (M.A) Pada Program Pascasarjana Institut IImu Sosial Dan Manajemen STIAMI

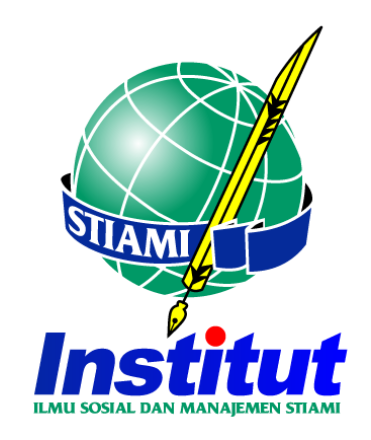

Disusun Oleh :

LIA HERIAWATI

BC41621043

KONSENTRASI : ADMINISTRASI PUBLIK

PROGRAM PASCASARJANA MAGISTER ILMU ADMINISTRASI INSTITUT ILMU SOSIAL DAN MANAJEMEN STIAMI JAKARTA 2018 


\section{PENGARUH PENERAPAN ELECTRONIC PROCUREMENT DAN GOOD GOVERNANCE TERHADAP KINERJA PENGADAAN \\ BARANG/JASA PADA BAGIAN PENGADAAN BARANG \\ DAN JASA SEKRETARIAT DAERAH \\ KABUPATEN PANDEGLANG}

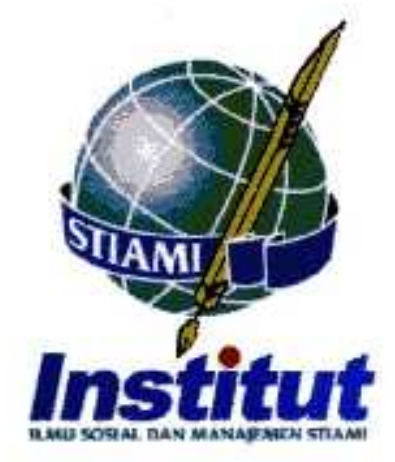

TESIS

Diajukan Guna Memenuhi Salah Satu Syarat Guna Memperoleh Gelar Magister Administrasi (M.A) Program Studi Ilmu Administrasi Telah Disetujui Oleh Tim Pembimbing dan Direktur Program Pada Tanggal Seperti Tertera Di Bawah Ini

Jakarta, 13 Nopember 2018

Menyetujui,

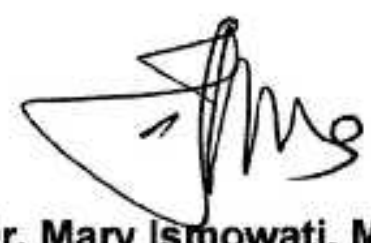

Dr. Mary Ismowati, M.Si

Pembimbing

Menyetujui,

Dr. Taufan Maulamin, SE, Ak, M.M.

Direktur Program 


\section{PENGARUH PENERAPAN ELECTRONIC PROCUREMENT DAN GOOD GOVERNANCE TERHADAP KINERJA PENGADAAN BARANG/JASA PADA BAGIAN PENGADAAN BARANG \\ DAN JASA SEKRETARIAT DAERAH KABUPATEN PANDEGLANG}

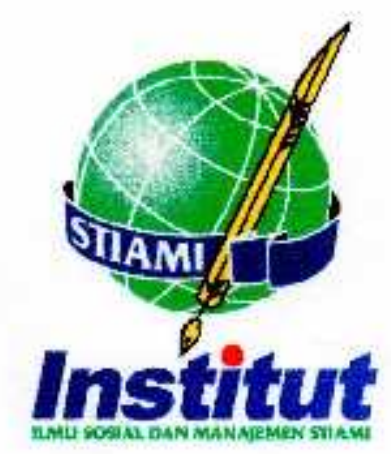

TESIS

Diajukan Guna Memenuhi Salah Satu Syarat Guna Memperoleh Gelar Magister Administrasi (M.A) Program Studi llmu Administrasi Telah Disetujui Oleh Tim Pembimbing dan Direktur Program Pada Tanggal Seperti Tertera Di Bawah Ini

$$
\text { Jakarta, } 13 \text { Nopember } 2018
$$

1. Dr. Bambang Irawan,M.Si,MM Ketua Penguji

2. Prof. Dr.A.Ramadhan Siregar,MS Penguji Ahli

3. Dr. Mary Ismowati, M.Si Pembimbing

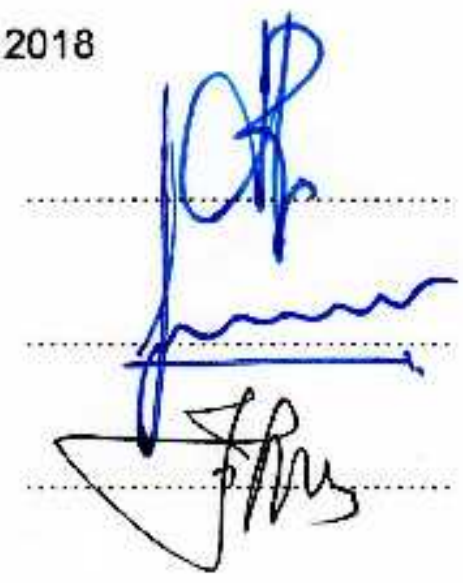

Mengesahkan,

Rektor Institut IImu Sosial dan Manajemen STIAMI

Dr. Ir. Panji Hendrarso, M.M NIK: 199714563 


\section{PERNYATAAN}

Dengan ini saya menyatakan bahwa :

1. Karya tulis saya, tesis ini, adalah asli dan belum pernah diajukan untuk mendapatkan gelar akademik (sarjana, magister, dan/atau doktor), baik di perguruan tinggi lain.

2. Karya tulis ini adalah murni gagasan, rumusan, dan penelitian saya sendiri, tanpa bantuan pihak lain, kecuali arahan Dosen Pembimbing/ Tim Promotor* dan masukan dari Tim Penelaah/Tim Penguji.

3. Dalam karya tulis ini tidak terdapat karya tulis atau pendapat yang telah ditulis atau dipublikasikan orang lain, kecuali secara tertulis jelas dicantumkan sebagai acuan dalam naskah dengan disebutkan nama pengarang dan dicantumkan dalam daftar pustaka.

4. Pernyataan ini saya buat dengan sesungguhnya dan apabila di kemudian hari terdapat penyimpangan dan ketidakbenaran dalam pernyataan ini, maka saya bersedia menerima sanksi akademik berupa pencabutan gelar yang telah diperoleh, serta sanksi lainnya sesuai dengan norma yang berlaku di perguruan tinggi.

Jakarta, 13 Nopember 2018

Yang Membuat Pernyataan

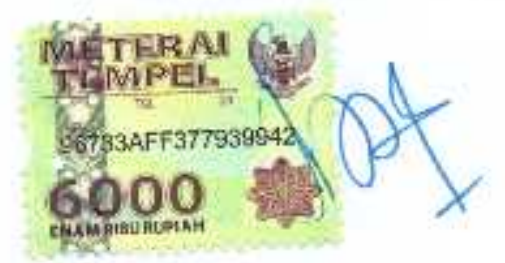

LIA HERIAWATI

BC41621043 


\section{KATA PENGANTAR}

Segala puji syukur penulis panjatkan kepada pemberi rahmat dan berkah, pemegang kekuasaan tertinggi Dzat Yang Maha Kuasa - Allah SWT, karena atas ijin-NYA sehingga tesis ini dapat diselesaikan. Merupakan suatu kebanggaan dan kebahagiaan bagi penulis dapat menyusun tesis ini dengan judul : "Pengaruh Penerapan E-Procurement dan Good Governance Terhadap Kinerja Pengadaan Barang/Jasa Pada Bagian Pengadaan Barang dan Jasa Sekretariat Daerah Kabupaten Pandeglang" pada Program Pascasarjana Institut IImu Sosial Dan Manajemen STIAMI Jakarta.

Penulis menyadari bahwa proses penyusunan tesis ini tidak mungkin terselesaikan tanpa bantuan dari berbagai pihak. Oleh karena itu dengan segala kerendahan hati penulis mengucapkan terima kasih yang tak terhingga kepada yang terhormat :

1. Yth. Bapak Dr. Ir. Panji Hendrarso, M.M. Selaku Rektor Institut IImu Sosial dan Manajemen STIAMI Jakarta;

2. Yth. Bapak Dr. Taufan Maulamin, SE, Akt, M.M. Selaku Direktur Program Pascasarjana Magister IImu Administrasi Institut IImu Sosial dan Manajemen STIAMI Jakarta; 
Sesungguhnya Allah Tidak akan mengubah Nasib Suatu kaum Sebelum Mereka Mengubah Diri Mereka Sendiri (Q.SAl-Ra'd 11)

"Barangsiapa yang mempelajarai llmu pengetahuan yang seharusnya yang ditunjukan untuk mencari ridho Allah bahkan hanya untuk mendapatkan kedudukan/kekayaan duniawi maka ia tidak akan mendapatkan baunya surga nanti pada hari kiamat (Riwayat Abu Hurairah Radiallahu Anhu)"

Persembahan Tesis ini adalah bagian dari ibadahku kepada Allah SWT, karena kepada-Nyalah kami menyembah dan kepada-Nyalah kami mohon pertolongan, sekaligus sebagai ungkapan terima kasihku kepada :

Suami,anak dan calon Bayiku yang selalu memberi inspirasi hidupku kedua Orang tua dan adiku yang selalu memberi motivasi dalam Hidupku 
3. Yth. Mary Ismowati, M.Si. Selaku Dosen Pembimbing dan Ketua Program Studi Magister IImu Administrasi Institut IImu Sosial dan Manajemen STIAMI Jakarta;

4. Para dosen Institut IImu Sosial dan Manajemen STIAMI Jakarta yang tidak dapat penulis sebutkan namanya satu persatu;

5. Kepala Bagian Pengadaan Barang dan Jasa Sekretariat Daerah Kabupaten Pandeglang;

6. Pegawai pada Bagian Pengadaan Barang dan Jasa Sekretariat Daerah Kabupaten Pandeglang;

7. Teman-teman seangkatan pada Institut IImu Sosial dan Manajemen STIAMI Jakarta.

Sekali lagi, terucap terima kasih atas selesainya tesis ini, kritik dan saran kami tunggu mengingat berbagai kekurangan yang masih ada dalam tesis ini. Terima kasih.

Jakarta, 13 Nopember 2018

\section{LIA HERIAWATI}




\section{ABSTRAK \\ Pengaruh Penerapan E-Procurement Dan Good Governance \\ Terhadap Kinerja Pengadaan Barang/Jasa Pada Bagian \\ Pengadaan Barang Dan Jasa Sekretariat Daerah Kabupaten Pandeglang.}

\section{Lia Heriawati}

Tujuan penelitian ini adalah untuk mengetahui dan memahami seberapa besar pengaruh Penerapan E-Procurement terhadap Kinerja Pengadaan Barang/Jasa, untuk mengetahui dan memahami seberapa besar pengaruh Good Governance terhadap Kinerja Pengadaan Barang/Jasa, dan untuk mengetahui dan memahami seberapa besar pengaruh Penerapan E-Procurement dan Good Governance secara bersama-sama terhadap Kinerja Pengadaan Barang/Jasa.

Metode yang digunakan dalam penelitian ini adalah metode kuantitatif analisis regresi untuk melihat seberapa besar pengaruh variabel bebas dan variabel terikat. Populasi penelitian ini adalah seluruh pegawai pada Bagian Pengadaan Barang dan Jasa Sekretariat Daerah Kabupaten Pandeglang sebanyak 41 orang. Penentuan sampel dengan menggunakan teknik total sampling, sehingga jumlah sampel yang digunakan sebanyak 41 orang responden. Setiap responden diberikan sebanyak 35 pernyataan dengan menggunakan skala Likert. Analisis data menggunakan analisis kuantitatif dengan alat uji regresi linier sederhana dan berganda, uji t, uji F, uji korelasi dan determinasi.

Berdasarkan hasil dari pengolahan data menunjukkan bahwa Penerapan E-Procurement berpengaruh positif dan signifikan terhadap Kinerja Pengadaan Barang/Jasa sebesar 34,61 \%. Kemudian Good Governance berpengaruh positif dan signifikan terhadap Kinerja Pengadaan Barang/Jasa sebesar 10,06 \%. Sedangkan Penerapan EProcurement dan Good Governance secara bersama-sama berpengaruh positif dan signifikan terhadap Kinerja Pengadaan Barang/Jasa sebesar 44,67 \%. Hal ini menunjukkan bahwa semakin baik Penerapan EProcurement dan Good Governance, maka akan semakin meningkatkan Kinerja Pengadaan Barang/Jasa.

Kata Kunci : Penerapan E-Procurement, Good Governance, dan Kinerja Pengadaan Barang/Jasa. 


\title{
ABSTRACT
}

\author{
The Influence of E-Procurement and Good Governance \\ Implementation toward The Performance of Goods/Services \\ Procurement in Division of Goods and Services Procurement of \\ Regional Secretary in Pandeglang Regency

\section{Lia Heriawati}

This research aims to know and understand about how big the influence of E-Procurement's Implementation is toward Performance of Goods/ Services Procurement, and to know and understand how big the influence of Good Governance's implementation toward The Performance of Procurement of Goods/Services, and to know and understand about how big the influence of E-Procurement and Good Governance's Implementation collectively toward The Performance of Procurement of Goods/Services.

Method that is used in this research is qualitative method of regression analysis to see how big the influence of independent variable and dependent variable are. Population of this research is all of employees in Division of Procurement of Goods and Services of Regional Secretary in Pandeglang Regency in total of 41 people. The Determination of sample is using a total sampling technique, therefore the amount of sample that is used in total of 41 responder. Each responder is given about 35 statements with using Likert scale. Data analysis is using qualitative analysis with linear regression test and double, test $t$, test $F$, correlation test and determination.

Based on the result from data management shows that The Implementation of E-Procurement has a positive impact and significant toward The Performance of Procurement of Goods/Services in total of $34,61 \%$. Thereafter Good Governance has a positive impact and significant toward The Performance of Procurement of Goods and Services in total of 10,06 \%. Whereas The Implementation of EProcurement and Good Governance are having a positive impact and significant collectively toward The Performance of Procurement of Goods/Services in total of $44,67 \%$. This matter shows that the better of $E$ Procurement's implementation is and Good Governance, thereafter the more Performance of procurement Goods/Services increases.

Key words : Implementation of E-Procurement, good Services, and Performance of Procurement Goods/ Services. 


\section{DAFTAR ISI}

Hal

KATA PENGANTAR .......................................................... vi

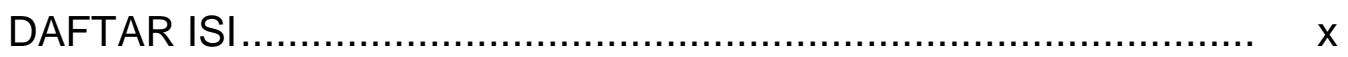

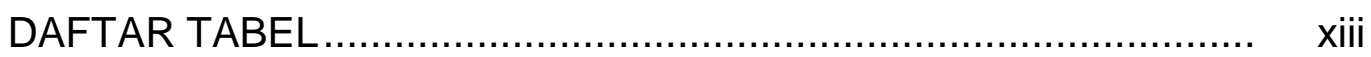

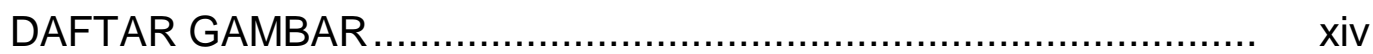

BAB I PENDAHULUAN

A. Latar Belakang Penelitian .................................... 1

B. Identifikasi Masalah ........................................ 8

C. Pembatasan Masalah ............................................. 9

D. Perumusan Masalah ........................................... 10

E. Tujuan Penelitian ............................................. 11

F. Manfaat Penelitian ......................................... 11

BAB II KAJIAN LITERATUR, KERANGKA PEMIKIRAN,

DAN HIPOTESIS

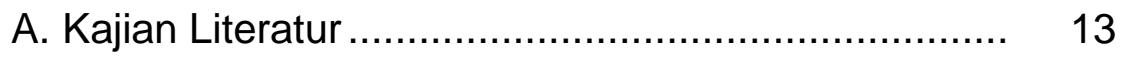

A.1. Teori Pengadaan Barang dan Jasa ................. 13

A.2. Teori Electronic Procurement .......................... 15

A.3. Teori Good Governance .................................. 32

A.4. Teori Kinerja Lembaga .................................... 41

A.5. Penelitian Terdahulu ..................................... 55 
B. Kerangka Konseptual dan Model Penelitian

B.1. Pengaruh Penerapan Electronic Procurement Terhadap Kinerja Pengadaan Barang/Jasa Pada Bagian Pengadaan Barang dan Jasa Sekretariat Daerah Kabupaten Pandeglang ....

B.2. Pengaruh Good Governance Terhadap Kinerja Pengadaan Barang/Jasa Pada Bagian Pengadaan Barang dan Jasa Sekretariat Daerah Kabupaten Pandeglang .... 63

B.3. Pengaruh Penerapan Electronic Procurement Dan Good Governance Secara Bersama-sama Terhadap Kinerja Pengadaan Barang/jasa Pada Bagian Pengadaan Barang dan Jasa Sekretariat Daerah Kabupaten Pandeglang .... 65

C. Hipotesis 68

BAB III METODE PENELITIAN

A. Pendekatan Penelitian ....................................... 69

B. Operasionalisasi Variabel .................................... 71

C. Teknik Pengumpulan Data .................................. $\quad 74$

D. Teknik Sampling ................................................ 76

E. Teknik Analisis Data............................................. 77

F. Lokasi dan Jadwal Penelitian ................................ 85

BAB IV HASIL PENELITIAN DAN PEMBAHASAN

A. Hasil Penelitian ................................................. 87

A.1. Gambaran Umum Obyek Penelitian ............ 87

A.2. Deskripsi Responden Penelitian.................... 94 
A.3. Hasil Uji Validitas ....................................... 95

A.4. Reliabilitas Instrumen ................................. 98

A.5. Analisis Deskriptif Hasil Penelitian................ 99

A.6. Method of Successive Interval (MSI) ............ 105

A.7. Uji Asumsi Klasik.......................................... 107

A.8. Pengujian Hipotesis..................................... 112

A.9. Analisis Jalur ............................................. 118

B. Pembahasan .................................................. 121

B.1. Pengaruh Penerapan Electronic Procurement Terhadap Kinerja Lembaga Pada Bagian

Pengadaan Barang dan Jasa Sekretariat Daerah Kabupaten Pandeglang

B.2. Pengaruh Good Governance Terhadap Kinerja Lembaga Pada Bagian Pengadaan Barang dan Jasa Sekretariat Daerah Kabupaten Pandeglang

B.3. Pengaruh Penerapan Electronic Procurement Dan Good Governance Secara Bersama-sama Terhadap Kinerja Lembaga Pada Bagian Pengadaan Barang dan Jasa Sekretariat Daerah Kabupaten Pandeglang

BAB V SIMPULAN DAN SARAN

A. Simpulan

B. Saran

DAFTAR PUSTAKA 


\section{DAFTAR TABEL}

Tabel 2.1 Penelitian Terdahulu ................................................ 59

Tabel 3.1 Kisi-kisi Variabel ........................................................ 73

Tabel 3.2 Populasi Responden ................................................ 76

Tabel 3.3 Jadwal Penelitian ...................................................... 86

Tabel 4.1 Hasil Uji Validitas Variabel Penerapan E-Procurement

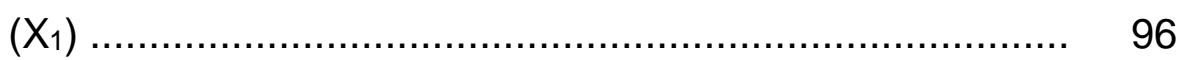

Tabel 4.2 Hasil Uji Validitas Variabel Good Governance $\left(X_{2}\right) \ldots \ldots \ldots . . \quad 97$

Tabel 4.3 Hasil Uji Validitas Variabel Kinerja Lembaga $(\mathrm{Y}) \ldots \ldots \ldots \ldots \ldots . . . \quad 98$

Tabel 4.4 Deskriptif Statistik Penerapan E-Procurement ................ 100

Tabel 4.5 Distribusi Frekuensi Penerapan E-Procurement .............. 100

Tabel 4.6 Deskriptif Statistik Good Governance ........................... 102

Tabel 4.7 Distribusi Frekuensi Good Governance ......................... 102

Tabel 4.8 Deskriptif Statistik Kinerja Lembaga ............................. 104

Tabel 4.9 Distribusi Frekuensi Kinerja Lembaga ........................... 104

Tabel 4.10 Hasil Transformasi MSI ............................................ 106

Tabel 4.11 Uji Normalitas Variabel............................................. 107

Tabel 4.12 Uji Multikolinearitas ................................................ 109

Tabel 4.13 Uji Autokorelasi .................................................... 110

Tabel 4.14 Hasil Uji Statistik t ................................................... 114

Tabel 4.15 Hasil Uji Statistik F ............................................ 116

Tabel 4.16 Matriks Koefisien Korelasi Variabel Penelitian ............... 118 


\section{DAFTAR GAMBAR}

Gambar 2.1 Model Kerangka Konseptual Penelitian ..................... 67

Gambar 3.1 Design Penelitian .................................................. 71

Gambar 4.1 Histogram Distribusi Frekuensi Variabel

Penerapan E-Procurement...................................... 101

Gambar 4.2 Histogram Distribusi Frekuensi Variabel

Good Governance .................................................... 103

Gambar 4.3 Histogram Distribusi Frekuensi Variabel Kinerja

Lembaga .......................................................... 105

Gambar 4.4 Grafik Scatterplot Uji Heterokedastisitas ................... 111

Gambar 4.5 Nilai Koefisien Jalur Variabel Penelitian ...................... 119 


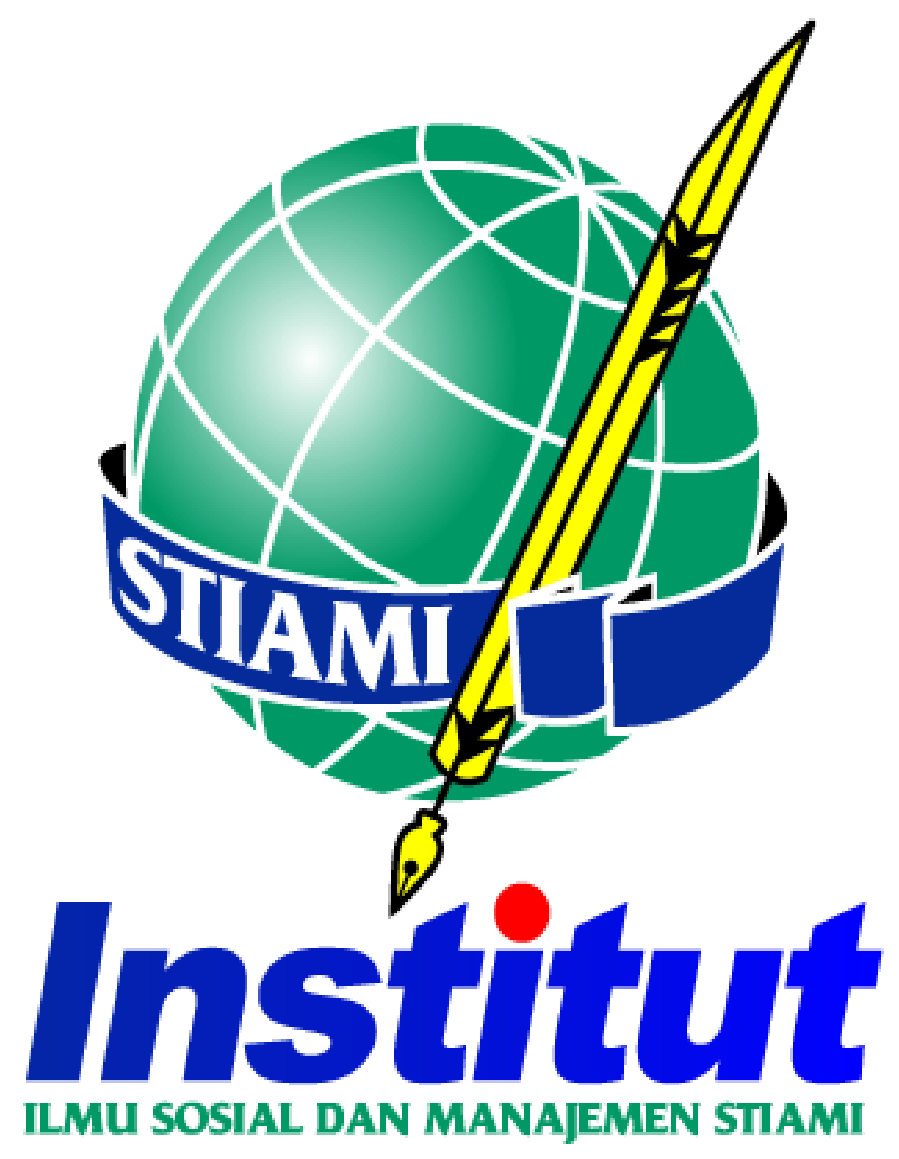




\section{BAB I}

\section{PENDAHULUAN}

\section{A. Latar Belakang Penelitian}

Banyak organisasi menghabiskan paling sedikit satu pertiga dari keseluruhan anggaran untuk pengadaan barang/jasa tak terkecuali pengadaan pada sektor publik yang pada umumnya termasuk bagian terbesar dari pengeluaran pemerintah selain dari gaji pemerintah dan tunjangan sosial. Meskipun demikian terdapat penelitian yang menemukan adanya ketidakefisienan pada proses pengadaan barang/jasa kemudian akan turut berdampak pada kinerja pengadaan. Oleh sebab itu proses pengadaan barang/jasa perlu dilakukan secara online untuk dapat membantu pemerintah dalam mengontrol pengeluaran yang dilakukan instansi pemerintah dan pada akhirnya turut berdampak pada kinerja pengadaan barang/jasa.

E-procurement termasuk salah satu alat pengadaan barang/jasa online yang dapat digunakan instansi pemerintah dalam mengontrol pengeluaran instansi pemerintah sampai akhirnya juga diharapkan oleh banyak pihak dapat menciptakan tata kelola pemerintahan yang baik pada sektor pemerintahan seperti meningkatkan transparansi, efisiensi, efektivitas dan akuntabilitas. Eprocurement dapat menjadi alat untuk mencapai tatakelola pemeritah yang baik karena e-procurement memberikan kesempatan untuk semua pihak turut terlibat dalam proses pengadaan barang dan jasa 
secara virtual baik dengan melakukan tender maupun mengawasi proses pengadaan barang dan jasa yang dilakukan oleh pemerintah.

Pengembangan E-procurement dilakukan melalui tahapantahapan sebagai berikut: (1) Copy To Internet yaitu kegiatan penayangan seluruh proses dan hasil pengadaan barang/jasa, ditayangkan melalui internet (sistem lelang) oleh panitia pengadaan; (2) Semi E-procurement yaitu kegiatan pengadaan barang/ jasa yang sebagian prosesnya dilakukan melalui media elektronik (internet) secara interaktif antara pengguna jasa dan penyedia jasa dan sebagian lagi dilakukan secara manual (konvensional); (3) Full Eprocurement yaitu proses pemilihan penyedia barang/jasa yang dilakukan dengan cara memasukkan dokumen (file) penawaran melalui sistem E-procurement, sedangkan penjelasan dokumen seleksi/lelang masih dilakukan secara tatap muka antara pengguna jasa dengan penyedia jasa.

Adapun kendala yang dihadapi adalah kurangnya dukungan finansial, dimana beberapa instansi dan penyedia jasa lebih nyaman dengan sistem sebelumnya, kurang dukungan dari tingkat atas manajemen, belum meratanya keterampilan dan pengetahuan tentang e-procurement, serta jaminan sistem keamanan atas e-procurement itu sendiri. Penyebab hambatan sistem e-procurement dapat ditelaah lebih lanjut dan dilihat dari sisi peraturan perundangan, sumber daya manusia dan perangkat keras dan infrastruktur jaringan. 
Dengan adanya sistem e-procurement ini, maka kinerja institusi pemerintahan yang ada diharapkan akan meningkat, karena pembelian dibuat dengan memilih item-item yang ada didalam sistem sehingga dapat mengurangi kecenderungan kesalahan. Semua tender pemilihan barang dan jasa pemerintah dilakukan secara online melalui internet sehingga proses menjadi efektif dan efisien serta transparan. Hal tersebut yang sudah dipaparkan secara tidak langsung akan mempengaruhi kinerja proses operasional yang berada dalam lembaga tersebut. Kinerja yang baik, khususnya dalam bidang pengadaan akan mendukung proses berjalannya transparansi dan persaingan yang sehat antar penyedia barang dan jasa juga bagi aparatur pemerintah, sehingga mengurangi intensitas pertemuan langsung antara penyedia barang dan jasa dengan panitia pengadaan dalam mendukung pemerintahan yang bersih dan bebas dari KKN. Dan kepercayaan yang dibutuhkan juga akan mempengaruhi proses penerapan aplikasi e-procurement dalam memberikan dampak kepada keikutsertaan e-marketplace didalamnya.

Tata kelola pemerintahan yang baik dan bersih (Good Governance and Clean Goverment) adalah seluruh aspek yang terkait dengan kontrol dan pengawasan terhadap kekuasaan yang dimiliki pemerintah dalam menjalankan fungsinya melalui institusi formal dan informal. Untuk melaksanakan prinsip Good Governance and Clean Goverment, maka pemerintah harus 
melaksanakan prinsip-prinsip akuntabilitas dan pengelolaan sumber daya secara efisien, serta mewujudkannya dengan tindakan dan peraturan yang baik dan tidak berpihak (independen), serta menjamin terjadinya interaksi ekonomi dan sosial antara para pihak terkait (stakeholder) secara adil, transparan, profesional dan akuntabel.

Pada lingkungan Sekretariat Daerah Kabupaten Pandeglang dalam upaya membangun pemerintahan yang baik (good goodvernance) dan transparan telah dilakukan berbagai upaya, seperti diantaranya peningkatan Kinerja Pengadaan Barang dan Jasa. Peningkatan Kinerja Pengadaan Barang dan Jasa juga diterapkan dalam rangka meningkatkan daya guna dan hasil guna pelaksanaan program kerja dan kegiatan-kegiatan, yang diselenggarakan secara bertanggung jawab dan bersih sebagai pertanggung jawaban pelaksanaan tugas dan fungsi serta kewenangan dan kebijaksanaan dalam pencapaian visi, misi dan tujuan organisasi. Beberapa kebijakan daerah dibuat dengan tujuan untuk mengembangkan sumber daya yang ada, agar menghasilkan Kinerja Pengadaan Barang dan Jasa yang optimal.

Berdasarkan hasil observasi yang lakukan di Pemerintah Kabupaten Pandeglang, Kinerja Pengadaan Barang dan Jasa yang ada masih rendah. Hal ini dapat dilihat dari fenomena pegawai yang ada diketahui belum semua pegawai memiliki komitmen yang kuat terhadap kinerja pengadaan barang dan jasa seperti beberapa 
pegawai memiliki kemampuan yang lemah dalam melaksanakan pekerjaan yang tidak dapat diselesaikan sesuai target waktu. Selain itu dalam pelaksanaan proses seleksi perusahaan pemenang lelang masih ditemukan adanya kejanggalan seperti panitia menyeleksi perusahaan pemenang dengan nilai penawaran terendah, sementara penewaran tertinggi tidak dievaluasi. Hal ini diduga disebabkan oleh adanya faktor penerapan elektronic procurement dan good governance. Selain itu adanya faktor lain diduga juga dapat mempengaruhi Kinerja Pengadaan Barang dan Jasa yaitu kepemimpinan, kompensasi, koordinasi, budaya kerja, disiplin kerja, pendidikan formal, fasilitas kerja, kualitas sumber daya manusia, perencanaan sumber daya manusia, kompetensi jabatan, budaya organisasi, pengawasan melekat dan lain-lain.

Kinerja Pengadaan Barang dan Jasa pada Pemerintah Kabupaten Pandeglang dapat dipengaruhi oleh faktor penerapan electronic procurement. Electronic Procurement dapat diartikan sebagai sebuah website yang merupakan sistem lelang dalam pengadaan barang oleh pemerintah dengan menggunakan sarana teknologi, informasi dan komunikasi berbasis internet.

Dari hasil penelitian sementara pada Pemerintah Kabupaten Pandeglang, penerapan electronic procurement yang ada masih rendah. Hal ini disebabkan oleh belum diterapkannya electronic procurement sebagai alat untuk proses penyediaan barang/jasa 
sehingga proses pengadaan barang masih belum transparan dan belum dapat diakses oleh masyarakat.

Kinerja Pengadaan Barang dan Jasa pada Pemerintah Kabupaten Pandeglang juga dapat dipengaruhi oleh faktor good governance. Secara umum, governance diartikan sebagai kualitas hubungan antara pemerintah dan masyarakat yang dilayani dan dilindunginya, private sectors (sektor swasta/ dunia usaha), dan society (masyarakat). Oleh sebab itu, good governance sektor publik diartikan sebagai suatu proses tata kelola pemerintahan yang baik, dengan melibatkan stakeholders terhadap berbagai kegiatan perekonomian, sosial politik, dan pemanfaatan berbagai sumber daya seperti sumber daya alam, keuangan, dan manusia bagi kepentingan rakyat yang dilaksanakan dengan menganut asas keadialan, pemerataan, persamaan, efisiensi, transparansi dan akuntabilitas.

Sebagaimana dalam pengembangan kapasitas good governance, ada yang disebut dengan perubahan dalam distribusi kewenangan yaitu telah terjadi distribusi kewenangan yang tadinya menumpuk di pusat untuk didesentralisasikan kepada daerah, masyarakat, asosiasi dan berbagai kelembagaan yang ada di masyarakat. Artinya saat ini pemerintah bukanlah satu-satunya aktor dalam pengambilan keputusan, masyarakat dan juga pihak swasta pun berkesempatan untuk terlibat dalam pengambilan keputusan. 
Berdasarkan hasil observasi pada Pemerintah Kabupaten Pandeglang, good governance masih lemah. Hal ini disebabkan oleh perbaikan sistem birokrasi belum berjalan sesuai dengan tuntutan masyarakat. Hal tersebut terkait dengan tingginya kompleksitas dalam mencari solusi perbaikan. Selain itu masih lemahnya pengawasan terhadap kinerja aparatur negara yang berakibat pada kondisi kinerja birokrasi yang masih jauh dari harapan. Banyaknya permasalah birokrasi tersebut belum sepenuhnya teratasi, baik dari sisi internal maupun eksternal.

Dari sisi internal, faktor demokrasi dan desentralisasi telah membawa dampak pada proses pengambilan keputusan kebijakan publik. Dampak tersebut terkait dengan makin meningkatnya tuntutan akan partisipasi masyarakat dalam kebijakan publik, meningkatnya tuntutan penerapan prinsip tata kepemerintahan yang baik antara lain transparansi, akuntabilitas, dan kualitas kinerja publik serta taat hukum. Secara khusus dari sisi internal birokrasi, berbagai permasalahan masih banyak yang dihadapi, antara lain pelanggaran disiplin, penyalahgunaan kewenangan, dan masih terdapat praktik KKN. Dari sisi eksternal, faktor globalisasi dan revolusi teknologi informasi (e-government) merupakan tantangan tersendiri dalam upaya menciptakan pemerintahan yang bersih, baik, dan berwibawa. Hal tersebut terkait dengan makin meningkatnya 
ketidakpastian akibat perubahan faktor lingkungan politik, ekonomi, dan sosial yang terjadi dengan cepat.

Berdasarkan pada permasalahan yang telah diuraikan di atas serta mengingat akan arti pentingnya pemecahan Kinerja Pengadaan Barang dan Jasa, maka penulis merasa perlu untuk melakukan penelitian tentang : “Pengaruh Penerapan Electronic Procurement dan Good Governance Terhadap Kinerja Pengadaan Barang/Jasa Pada Bagian Pengadaan Barang Dan Jasa Sekretariat Daerah Kabupaten Pandeglang".

\section{B. Identifikasi Masalah}

Dengan memperhatikan pada latar belakang masalah di atas, untuk melakukan penelitian lebih terarah maka masalah tersebut perlu diidentifikasi sehingga dapat diketahui sebab terjadinya masalah tersebut yang pada gilirannya akan diteliti sesuai dengan batasan kemampuan peneliti. Dengan demikian, penulis mengidentifikasikan masalah pada penelitian ini sebagai berikut :

1. Penerapan Electronic Procurement masih rendah.

2. Lingkungan kerja yang ada masih lemah dan sering menimbulkan ketidakselarasan dalam bekerja.

3. Good Governance yang diterapkan masih lemah.

4. Gaya Kepemimpinan yang ada masih kurang memuaskan.

5. Perencanaan Sumber Daya Manusia masih rendah. 
6. Motivasi yang ada masih rendah.

7. Disiplin kerja masih lemah.

8. Profesionalisme pegawai yang ada masih lemah.

9. Fasilitas kerja yang ada masih kurang memadai.

10. Pengawasan Melekat yang ada masih lemah.

11. Prestasi Kerja pegawai masih kurang memuaskan.

12. Kompensasi masih belum memuaskan.

13. Pemberian hukuman terhadap penegakkan disiplin pegawai belum optimal.

14. Budaya kerja masih lemah.

15. Komunikasi yang ada masih lemah.

16. Budaya organisasi masih rendah.

17. Latar belakang pendidikan masih rendah.

18. Koordinasi baik antar pegawai maupun antar bagian masih sering menimbulkan ketidakselarasan dalam bekerja.

\section{Pembatasan Masalah}

Dengan memperhatikan pada hasil identifikasi masalah di atas, maka penelitian ini dibatasi pada pengkajian tentang Penerapan Electronic Procurement dan Good Governance dalam kaitannya dengan Kinerja Pengadaan Barang/Jasa pada Bagian Pengadaan Barang dan Jasa Sekretariat Daerah Kabupaten Pandeglang. Pembatasan tersebut bermaksud untuk membuat ruang lingkup 
penelitian menjadi lebih fokus, sehingga pelaksanaan maupun analisisnya dapat dilakukan secara lebih tajam dan akurat.

\section{Perumusan Masalah}

Perumusan masalah dalam penelitian mengenai Pengaruh Penerapan Electronic Procurement dan Good Governance terhadap Kinerja Pengadaan Barang/Jasa pada Bagian Pengadaan Barang dan Jasa Sekretariat Daerah Kabupaten Pandeglang adalah sebagai berikut :

1. Seberapa besar pengaruh Penerapan Electronic Procurement terhadap Kinerja Pengadaan Barang/Jasa pada Bagian Pengadaan Barang dan Jasa Sekretariat Daerah Kabupaten Pandeglang ?

2. Seberapa besar pengaruh Good Governance terhadap Kinerja Pengadaan Barang/Jasa pada Bagian Pengadaan Barang dan Jasa Sekretariat Daerah Kabupaten Pandeglang?

4. Seberapa besar pengaruh Penerapan Electronic Procurement dan Good Governance secara bersama-sama terhadap Kinerja Pengadaan Barang/Jasa pada Bagian Pengadaan Barang dan Jasa Sekretariat Daerah Kabupaten Pandeglang? 


\section{E. Tujuan Penelitian}

Adapun tujuan dari penelitian ini adalah :

1. Untuk menanalisis dan mengevaluasi besarnya pengaruh Penerapan Electronic Procurement terhadap Kinerja Pengadaan Barang/Jasa pada Bagian Pengadaan Barang dan Jasa Sekretariat Daerah Kabupaten Pandeglang.

2. Untuk menanalisis dan mengevaluasi besarnya pengaruh Good Governance terhadap Kinerja Pengadaan Barang/Jasa pada Bagian Pengadaan Barang dan Jasa Sekretariat Daerah Kabupaten Pandeglang.

3. Untuk menanalisis dan mengevaluasi besarnya Penerapan Electronic Procurement dan Good Governance secara bersamasama terhadap Kinerja Pengadaan Barang/Jasa pada Bagian Pengadaan Barang dan Jasa Sekretariat Daerah Kabupaten Pandeglang.

\section{F. Manfaat Penelitian}

Diharapkan hasil penelitian ini dapat memberikan sumbangan bagi ilmu pengetahuan dan pemerintahan daerah, baik secara teoritis maupun praktis. 
1. Kegunaan Teoritis

a. Bagi Para Peneliti

Manfaat bagi para peneliti hasil penelitian ini diharapkan dapat menjadi masukan terutama bagi mereka yang menaruh minat untuk menindaklanjuti hasil penelitian ini dengan mengambil kancah penelitian yang berbeda dan dengan sampel penelitian yang lebih banyak.

b. Bagi Kalangan Akademisi

Manfaat bagi kalangan akademisi hasil penelitian ini diharapkan dapat memperkaya khasanah kepustakaan ilmu mengenai pengaruh Penerapan Electronic Procurement dan Good Governance secara bersama-sama terhadap Kinerja Pengadaan Barang/Jasa pada Bagian Pengadaan Barang dan Jasa Sekretariat Daerah Kabupaten Pandeglang.

2. Kegunaan Praktis

Kegunaan praktis dari hasil penelitian ini adalah untuk memberikan gambaran mengenai belum optimalnya Kinerja Pengadaan Barang/Jasa pada Bagian Pengadaan Barang dan Jasa Sekretariat Daerah Kabupaten Pandeglang dan hubungannya dengan kedua faktor yang telah diungkapkan diatas. 


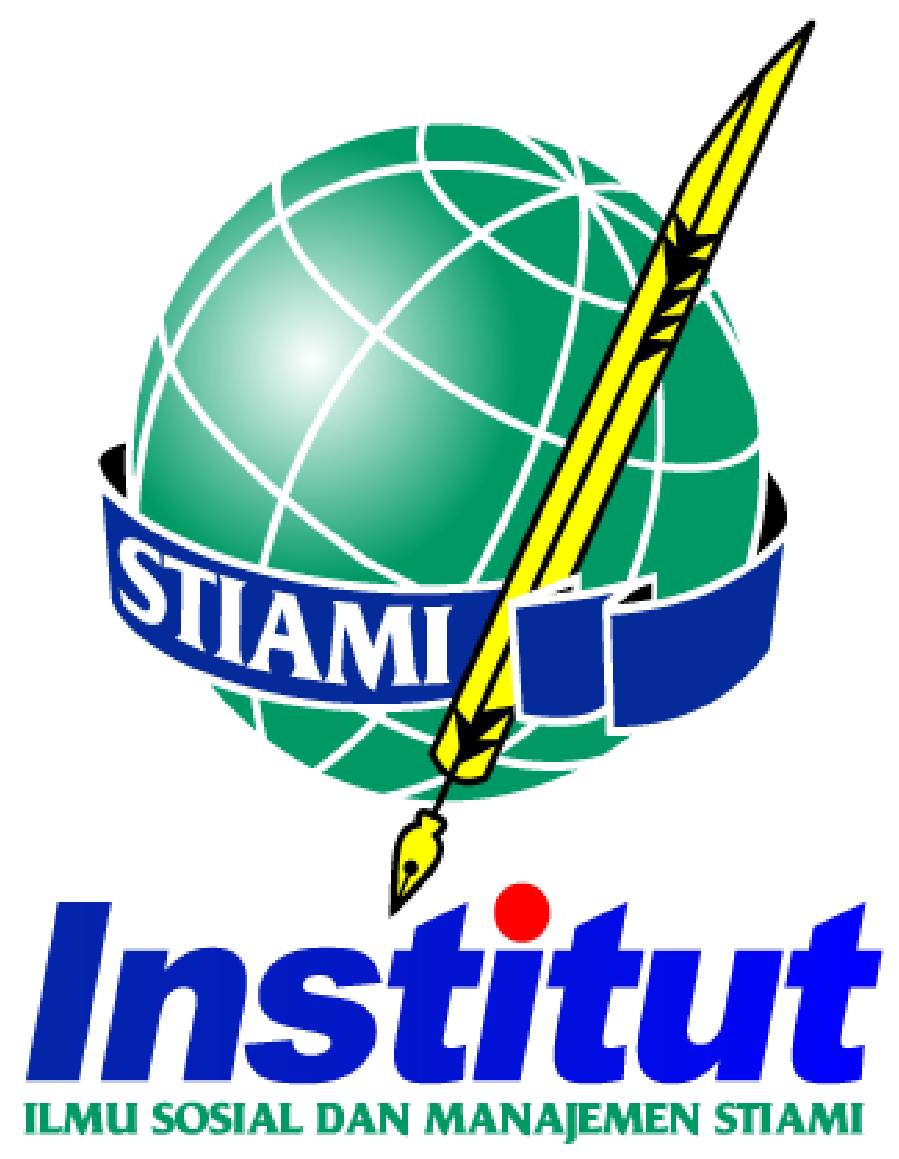




\section{BAB II}

\section{KAJIAN LITERATUR, KERANGKA PEMIKIRAN, DAN HIPOTESIS}

\section{A. Kajian Literatur dan Penelitian Terdahulu}

\section{A.1. Teori Administrasi}

Istilah Administrasi secara etimologi berasal dari bahasa Latin (Yunani) yang terdiri atas dua kata yaitu "ad" dan "ministrate" yang berarti "to serve" yang dalam Bahasa Indonesia berarti melayani atau memenuhi. Sedangkan pendapat A. Dunsire yang dikutip ulang oleh Keban (2008 : 2) administrasi diartikan sebagai arahan, pemerintahan, kegiatan implementasi, kegiatan pengarahan, penciptaan prinsip-prinsip implementasi kebijakan publik, kegiatan melakukan analisis, menyeimbangkan dan mempresentasikan keputusan, pertimbangan-pertimbangan kebijakan, sebagai pekerjaan individual dan kelompok dalam menghasilkan barang dan jasa publik, dan sebagai arena bidang kerja akademik dan teoritik.

Administrasi juga dapat diartikan sebagai kegiatan yang dilakukan untuk mengendalikan suatu pemerintah agar tujuan tercapai. Menurut pendapat Prof. Dr. H. Hadari Nawawi dan Dra. H. M. Martini Hadari dalam buku Ilmu Administrasi (1994 : 28) disebutkan Administrasi adalah rangkaian kegiatan atau proses pengendalian suatu organisasi agar secara keseluruhan selalu terarah pada pencapaian tujuannya. 
Dengan demikian Administrasi berarti rangkaian kegiatan atau proses pengendalian cara atau sistem kerja sama sejumlah orang, agar berlangsung efektif dan efisien dalam mewujudkan tujuan bersama.

Para praktisi cenderung pada administrasi dalam pengertian operasional, dengan demikian rumusan-rumusan para ilmuwan yang bergerak dilingkuangan IImu Administrasi harus bersifat applaid (terpakai) agar dapat dipetik manfaatnya oleh orang-orang yang menempati posisi sebagai administrator.

Menurut Handayaningrat (2002:2) dalam bukunya Pengantar Studi IImu Administrasi dan Manajemen sebagai berikut :

Administrasi secara sempit berasal dari kata Administratie (bahasa Belanda) yaitu meliputi kegiatan catat-mencatat, surat-menyurat, pembukuan ringan, ketik-mengetik, agenda dan sebagainya yang bersifat teknis ketatausahaan (clerical work).

Dari definisi tersebut dapat disimpulkan administrasi dalam arti sempit merupakan kegiatan ketatausahaan yang meliputi kegiatan catat-mencatat, surat-menyurat, pembukuan dan pengarsipan surat serta hal-hal lainnya yang dimaksudkan untuk menyediakan informasi serta mempermudah memperoleh informasi kembali jika dibutuhkan.

Administrasi secara umum dapat diartikan sebagai suatu proses yang dilakukan secara kerjasama untuk mencapai tujuan bersama yang telah ditentukan sebelumnya. Apabila diterapkan 
secara formal dalam organisasi maka proses kerjasama tersebut adalah dalam upaya mewujudkan tujuan organisasi.

Sondang P. Siagian (1974:2) mengatakan bahwa Administrasi adalah :

"Keseluruhan proses pelaksanaan daripada keputusan yang telah diambil dan pelaksanaan itu pada umumnya dilakukan oleh dua orang manusia atau lebih untuk mencapai tujuan yang telah ditentukan sebelumnya".

Dari pengertian ini dapat diartikan bahwa Administrasi merupakan keseluruhan proses pelaksanaan dari keputusan yang telah diambil oleh dua orang manusia atau lebih untuk mencapai tujuan yang telah ditentukan sebelumnya.

Adapun menurut Chander dan Plano (2004:3) mengemukakan bahwa :

"Administrasi Publik adalah proses dimana sumber daya dan personel publik diorganisir dan dikoordinasikan untuk memformulasikan, mengimplementasikan dan mengelola (manage) keputusan-keputusan dalam publik".

\section{A.2. Teori Electronic Procurement}

\section{A.2.1. Pengertian Electronic Procurement}

Djoyosoekarto (2008:10) mengidentifikasikan e-procurement sebagai pengadopsian sistem berbasis internet dalam proses pembelian.

Menurut Willem (2012:80) e-procurement, yaitu :

"Pengadaan secara elektronik (e-procurement) merupakan pelaksanaan pengadaan barang dan jasa dengan menggunakan jaringan elektronik (jaringan internet atau intranet) atau electronic data interchange (EDI)" 
Menurut Sutedi (2012:254), yaitu:

"E-procurement sebagai sebuah website yang merupakan sistem lelang dalam pengadaan barang oleh pemerintah dengan menggunakan sarana teknologi, informasi dan komunikasi berbasis internet."

Keputusan Presiden RI Nomor 54 Tahun 2010 tentang Pedoman Pengadaan Barang/Jasa Pemerintah menyatakan bahwa :

"Pengadaan secara elektronik atau E-procurement adalah Pengadaan Barang/Jasa yang dilaksanakan dengan menggunakan teknologi informasi dan transaksi elektronik sesuai dengan ketentuan perundang-undangan."

Berdasarkan beberapa definisi yang telah dikemukakan sebelumnya, maka dapat disimpulkan bahwa e-procurement mengacu pada pemanfaatan internet berdasarkan Teknologi Informasi dan Komunikasi (TIK) untuk membantu individu dan keseluruhan tingkatan proses pengadaan barang dan jasa.

Menurut A.H. Rahadian dan Irman Gapur (2015:3) sistem informasi merupakan suatu kumpulan dari komponen-komponen dalam organisasi dilingkungan pemerintah yang berhubungan dengan proses penciptaan dan pengaliran atau pendistribusian informasi.

Pengertian di atas diketahui bahwa untuk menyampaikan informasi agar proses penyampaian informasi dengan lebih cepat, akurat kepada para pengguna informasi tersebut yang biasanya menggunakan teknologi informasi yang berupa electronic 
goverment dengan mempergunakan media web sebagai penyampaian informasi, sehingga pengguna informasi mendapatkan nilai dan arti serta manfaat sebagai pemenuhan kebutuhanya, baik untuk keperluan lingkungan Instansi pemerintahan maupun masyarakat.

\section{A.2.2. Manfaat Electronic Procurement}

Pemanfaatan e-procurement juga menunjukkan bahwa teknologi juga dapat berkontribusi membenahi berbagai persoalan terkait pengadaan barang/jasa pemerintah yang mungkin sulit dicapai. Adapun manfaat e-procurement menurut Yudho Giri (2009:36) antara lain:

1. E-procurement memperluas akses pasar dan membantu menciptakan persaingan sehat (transparansi, harga yang lebih baik, dan pola interaksi yang lebih baik).

2. E-procurement juga memberikan rasa aman dan nyaman. Rasa aman karena proses pengadaan mengikuti ketentuan yang diatur secara elektronik dengan mengedepankan transparansi dan akuntabilitas, sehingga pemenang adalah penyedia barang/jasa yang telah mengikuti kompetisi dengan adil dan terbuka.

3. E-procurement juga berperan mengubah sikap para pelaku usaha untuk dapat terus meningkatkan kompetensinya. 
4. E-procurement juga memberikan manfaat lain diluar yang diperkirakan. Sebagai contoh, seluruh proses pengadaan, mulai dari pengumuman sampai dengan penetapan pemenang, tercatat dalam sistem.

5. E-procurement juga dapat digunakan sebagai sarana untuk monitoring dan evaluasi atas indikator kinerja pengadaan barang/jasa pemerintah yang dapat ditinjau dari beberapa kategori e-procurement juga meningkatkan perhatian terhadap fasilitas teknologi informasi.

6. E-procurement juga mengajak pihak yang terlibat untuk lebih mengenal dan mengerti teknologi informasi.

Menurut Sutedi (2012-254) manfaat lain dari pelaksanaan eprocurement yaitu :

"Dengan e-procurement proses lelang dapat berlangsung secara efektif, efisien, terbuka, besaing, transparan, adi/tidak diskriminatif dan akuntabel, sehingga diharapkan dapat mencerminkan keterbukaan/transparansi dan juga meminimalisir praktik curang/KKN dalam lelang pengadaan barang yang berakibat merugikan keuangan negara."

Dimitri (2006:21) dalam Badzlina Daroyani Novitaningrum (2014), mengemukakan keutamaan e-procurement yakni:

"...different from standard paper- based tendering, it is a common feeling among the surveyed institutions that an online auction is very useful because it allows the use of different kinds of auction formats (berbeda dengan proses lelang paper-based, terdapat berbagai pendapat dari kalangan institusi survei bahwa sistem online sangat bermanfaat karena mengadopsi berbagai macam format lelang)." 
Menurut Wardiyanto (2012:30):

"E-procurement akan sedikit banyak membantu sebagian proses interaksi dengan peserta lelang dengan meningkatkan efektifitas dan efisiensi dalam pengelolaan proses pengadaan barang/jasa pemerintah".

Pelaksanaan e-procurement yang dijalankan dengan baik dan benar dapat memberikan banyak manfaat salah satunya efisiensi waktu, dimana dengan adanya e-procurement waktu yang diperlukan dalam proses pengadaan barang dan jasa dapat diminimalkan sehingga paket-paket proyek lebih tepat waktu.

\section{A.2.3 Faktor Kesuksesan Penerapan atau Implementasi E- Procurement}

Yudho Giri (2009:38) menyatakan bahwa kesuksesan implementasi $e$ - procurement juga ditentukan oleh beberapa faktor berikut:

1. e-Leadership: implementasi e-procurement membutuhkan komitmen dan dukungan penuh dari pimpinan. Dukungan dari pimpinan perlu diwujudkan dalam wujud tindakan nyata dan bukan hanya sekedar wacana.

2. Transformasi pola pikir dan pola tindak: implementasi e-procurement memerlukan perubahan perilaku dan mental dari seluruh pihak yang terkait.

3. Jumlah dan mutu sumber daya manusia (SDM): teknologi tidak akan mungkin berjalan dengan sendirinya tanpa adanya pihak yang mengelola. Implementasi e-procurement membutuhkan 
jumlah SDM yang memadai. Tidak hanya dari sisi jumlah yang harus diperhatikan, namun juga dari sisi kompetensi yang mereka miliki.

4. Ketersediaan infrastruktur: infrastruktur yang dimaksud di sini mencakup banyak hal, dari mulai perangkat keras, piranti lunak, sampai kepada jaringan komunikasi dan sarana fisik lainnya.

Menurut Sutedi (2012:258) untuk menyukseskan pelaksanaan e-procurement, perlu diperhatikan beberapa faktor, yaitu :

"Kesiapan sumber daya manusia (SDM), infrastruktur ICT, serta perhatian dari pihak-pihak yang terlibat langsung dari pimpinan tertinggi hingga pegawai tingkat operasional."

Berdasarkan beberapa definisi yang telah dikemukakan sebelumnya, maka dapat disimpulkan bahwa kesuksesan implementasi e-procurement ditentukan oleh beberapa faktor, salah satunya dengan dukungan sumber daya manusia yang berkualitas, dimana semua proses e-procurement tidak terlepas dari dasar hukum yang telah ditetapkan.

\section{A.2.4. Tujuan E-procurement}

Tujuan diadakanya e-procurement menurut Sutedi (2012:258) adalah: 
"Untuk memudahkan sourcing, proses pengadaan dan pembayaran; memberikan komunikasi online antara buyer dengan vendor; mengurangi biaya proses dan administrasi pengadaan, menghemat biaya dan mempercepat proses."

Keputusan Presiden RI Nomor 70 Tahun 2012 tentang Pedoman Pengadaan Barang/Jasa Pemerintah disebutkan bahwa pengadaan barang dan jasa elektronik bertujuan untuk:

1. Meningkatkan transparansi dan akuntabilitas.

2. Meningkatkan akses pasar dan persaingan usaha yang sehat.

3. Memperbaiki tingkat efisiensi proses Pengadaan.

4. Mendukung proses monitoring dan audit.

5. Memenuhi kebutuhan akses informasi yang real time.

Peraturan Menteri BUMN Nomor Per-05/MBU/2008 tentang Pedoman Umum Pelaksanaan Pengadaan Barang/Jasa BUMN disebutkan bahwa pengadaan barang dan jasa elektronik bertujuan untuk:

1. Meningkatkan efisiensi.

2. Mendukung penciptaan nilai tambah di BUMN.

3. Menyederhanakan dan mempercepat proses pengambilan keputusan.

4. Meningkatkan kemandirian, tanggung jawab dan profesionalisme.

2. Meningkatkan penggunaan produksi dalam negeri.

3. Meningkatkan sinergi antar BUMN dan/atau Anak Perusahaan. 
Menurut James E Demin dari Infonet Service Corp dalam Dimas Aditya (2014) menyatakan bahwa tujuan dari eprocurement adalah sebagai berikut:

1. Untuk memperbaiki tingkat layanan kepada para pembeli, pemasok, dan pengguna.

2. Untuk mengembangkan sebuah pendekatan pengadaan yang lebih terintegrasi melalui rantai suplai perusahaan tersebut.

2. Untuk meminimalkan biaya-biaya transaksi terkait pengadaan melalui standarisasi, pengecilan, dan otomatisasi proses pengadaan di dalam dan dimana yang sesuai dengan agensiagensi dan sektor-sektor.

3. Untuk mendorong kompetisi antar pemasok sekaligus memelihara sumber pasokan yang dapat diandalkan.

4. Untuk mengoptimalkan tingkatan-tingkatan inventori melalui penerapan praktek pengadaan yang efisien.

5. Untuk mengefektifkan penggunaan sumber daya manusia dalam proses pengadaan.

6. Untuk mengurangi pengeluaran putus kontrak dengan menggunakan teknologi untuk meningkatkan kewaspadaan pengguna terhadap fasilitas-fasilitas kontrak yang ada dan membuatnya lebih mudah untuk menentangnya. 
7. Untuk meningkatkan kemampuan membeli dengan menggunakan teknologi untuk mendukung identifikasi peluang untuk penyatuan dan dengan memfasilitasi penyatuan persyaratan pengguna di dalam dan melalui garis-garis bisnis.

8. Mengurangi biaya-biaya transaksi dengan menggunakan teknologi untuk mengotomatisasikan proses-proses, yang mana masih tercetak(paper-based), dan untuk mengecilkan, dan menstandarisasi proses-proses dan dokumentasi.

Berdasarkan beberapa definisi yang telah dikemukakan sebelumnya, maka dapat disimpulkan bahwa tujuan dari $e$ procurement untuk meningkatkan kualitas pelaksanaan pengadaan barang dan jasa sehingga dapat menghemat waktu dan biaya serta menciptakan transparansi dalam proses nya.

\section{A.2.5. Proses Pelaksanaan E-procurement}

Menurut website (http://www.kpk.go.id/id/pengadaan/eprocurement-Ipse) Sistem Layanan Pengadaan Secara Elektronik (LPSE) adalah:

"Sistem pengadaan barang/jasa pemerintah yang dilaksanakan secara elektronik dengan memanfaatkan dukungan teknologi informasi. Sistem LPSE ini bertujuan untuk meningkatkan efisiensi, efektivitas, mutu, dan transparansi dalam pelaksanaan pengadaan barang dan jasa."

Berikut ini adalah tahapan e-procurement menurut website LPSE (Sumber: www.lpse.go.id), yaitu: 
1. Persiapan Pengadaan

a. PPK (Pejabat Pembuat Komitmen) menetapkan paket pekerjaan dalam SPSE (Sistem Pengadaan Secara Elektronik) dengan memasukkan: Nama paket, Lokasi, Kode anggaran, Nilai Pagu, Target pelaksanaan, dan Kepanitiaan.

b. Panitia Pengadaan memasukkan ke dalam SPSE:

i. Kategori paket pekerjaan;

ii. Metode pemilihan penyedia barang/jasa dan penyampaian dokumen penawaran yang meliputi:

- e-lelang Umum Pra Kualifikasi dua file;

- e-lelang Umum Pasca Kualifikasi satu file;

- e-lelang Umum Pasca Kualifikasi dua file.

iii. Metode Evaluasi pemilihan penyedia barang/jasa;

iv. Harga Perkiraan Sendiri;

v. Persyaratan kualifikasi;

vi. Jenis kontrak;

vii. Jadwal pelaksanaan lelang; dan viii. Dokumen Pemilihan.

2. Pengumuman Pelelangan

a. Setelah mendapatkan penetapan PPK, paket pekerjaan yang bersangkutan akan tercantum dalam website LPSE dan Panitia Pengadaan mengumumkan paket lelang 
sesuai dengan ketentuan yang berlaku.

b. Masyarakat umum dapat melihat pengumuman pengadaan di website LPSE yang bersangkutan.

3. Pendaftaran Peserta Lelang

a. Penyedia barang/jasa yang sudah mendapat hak akses dapat memilih dan mendaftar sebagai peserta lelang pada paket-paket pekerjaan yang diminati.

b. Dengan mendaftar sebagai peserta lelang pada paket pekerjaan yang diminati maka Penyedia barang/jasa dianggap telah menyetujui Pakta Integritas.

c. Dengan mendaftar sebagai peserta lelang pada paket pekerjaan yang diminati Penyedia barang/jasa dapat mengunduh (download) dokumen pengadaan/lelang paket pekerjaan tersebut.

4. Penjelasan Pelelangan

a. Proses penjelasan pelelangan dilakukan secara online tanpa tatap muka melalui website LPSE yang bersangkutan.

b. Jika dianggap perlu dan tidak dimungkinkan memberikan informasi lapangan ke dalam dokumen pemilihan, Panitia Pengadaan dapat melaksanakan proses penjelasan di lapangan/lokasi pekerjaan. 
5. Penyampaian Penawaran

a. Pada tahap penyampaian penawaran, Penyedia barangjasa yang sudah menjadi peserta lelang dapat mengirimkan dokumen (file) penawarannya dengan terlebih dahulu melakukan enkripsi/penyandian terhadap file penawaran dengan menggunakan Aplikasi Pengaman Dokumen (APENDO) yang tersedia dalam website LPSE.

b. Pengguna wajib mengetahui dan melaksanakan ketentuan penggunaan APENDO yang tersedia dan dapat diketahui pada saat mengoperasikan APENDO.

6. Proses Evaluasi

a. Pada tahap pembukaan file penawaran, Panitia Pengadaan dapat mengunduh (download) dan melakukan dekripsi file penawaran tersebut dengan menggunakan APENDO.

b. Terhadap file penawaran yang oleh tidak dapat dibuka, Panitia Pengadaan wajib menyampaikan file penawaran terenkripsi yang tidak dapat dibuka (dekripsi) kepada LPSE untuk dilakukan analisa dan bila dianggap perlu LPSE dapat menyampaikan file penawaran tersebut kepada Direktorat e-procurement LKPP (Lembaga Kebijakan Pengadaan Barang dan Jasa Pemerintah). 
c. Panitia Pengadaan dimungkinkan melakukan pemunduran jadwal pada paket pekerjaan tersebut.

d. Proses evaluasi (administrasi dan teknis, harga, kualifikasi) terhadap file penawaran dilakukan secara manual (off line) di luar SPSE, dan selanjutnya hasil evaluasi tersebut dimasukkan ke dalam SPSE.

e. Proses evaluasi kualifikasi dapat dilakukan dengan meminta dan memeriksa semua dokumen penawaran asli calon pemenang lelang.

7. Lelang Gagal dan Pelelangan Ulang

a. Dalam hal Panitia Pengadaan memutuskan untuk melakukan pelelangan ulang, maka terlebih dahulu Panitia Pengadaan harus membatalkan proses lelang paket pekerjaan yang sedang berjalan (pada tahap apapun) pada SPSE dan memasukkan alasan penyebab pelelangan harus diulang.

b. Informasi tentang pelelangan ulang ini secara otomatis akan terkirim melalui email kepada semua peserta lelang paket pekerjaan tersebut.

8. Pengumuman Calon Pemenang Lelang pada tahap pengumuman pemenang dan PPK telah menetapkan pemenang lelang suatu paket pekerjaan, SPSE secara otomatis akan menampilkan informasi pengumuman 
pemenang paket pekerjaan dimaksud, dan juga mengirim informasi ini melalui email kepada seluruh peserta lelang paket pekerjaan tersebut.

9. Sanggah

a. Peserta lelang hanya dapat mengirimkan 1 (satu) kali sanggahan kepada PPK suatu paket pekerjaan yang dilakukan secara online melalui SPSE.

b. SPSE memungkinkan PPK untuk melakukan jawaban terhadap sanggahan Peserta lelang yang dikirimkan setelah batas akhir waktu sanggah.

10. Pasca pengadaan

a. Proses pengadaan suatu paket selesai apabila PPK telah menetapkan pemenang lelang dan Panitia Pengadaan mengirimkan pengumuman pemenang lelang kepada Peserta lelang melalui SPSE serta masa sanggah telah dilalui.

b. SPSE secara otomatis akan mengirim pemberitahuan kepada pemenang lelang dan meminta untuk menyelesaikan proses selanjutnya yang pelaksanaannya di luar SPSE.

c. Dengan selesainya proses pengadaan melalui SPSE, PPK wajib membuat dan menyampaikan Surat Penetapan Pemenang kepada pemenang lelang secara 
tertulis.

d. Disertai dengan asli dokumen penawaran paket pekerjaan tertentu, pemenang lelang melakukan penandatanganan kontrak dengan pejabat terkait yang dilakukan di luar SPSE.

e. Pemenang lelang wajib menyelesaikan proses pengadaan di luar SPSE dengan pejabat Kementerian/Lembaga/Pemerintah daerah terkait.

f. Pengguna dan masyarakat pada akhir proses pengadaan dapat mengetahui pemenang lelang paket pekerjaan tertentu melalui website LPSE terkait.

\section{A.2.6. Dimensi Penerapan e-procurement}

Penerapan e-procurement sebagaimana telah diungkapkan oleh Willem (2012:11) yang menyatakan bahwa dalam pelaksanaan kegiatan pengadaan sejak perencanaan harus menerapkan prinsip pengadaan barang dan jasa berdasarkan prinsip efisien, efektif, kompetitif, transparan dan bertangungjawab. Berkaitan dengan dimensi penerapan eprocurement, Willem (2012:11-12) mengemukakan bahwa untuk mendukung penerapan e-procurement ada beberapa dimensi yang harus dipenuhi yang meliputi: 
1. Efisien

Pengadaan barang/jasa harus diusahakan dengan menggunakan dana, daya dan fasilitas yang sekecil-kecilnya untuk mencapai sasaran yang ditetapkan dalam waktu sesingkat-singkatnya dan dapat dipertanggungjawabkan dalam rangka memberikan kontribusi yang sebesar-besarnya bagi keuntungan negara.

2. Efektif

Sesuai dengan kebutuhan yang telah ditetapkan dan dapat memberikan manfaat yang sebesar-besarnya sesuai dengan sasaran yang ditetapkan.

3. Kompetitif

Dilakukan melalui seleksi dan persaingan yang sehat di antara penyedia barang/jasa yang setara dan memenuhi syarat/kriteria tertentu berdasarkan ketentuan dan prosedur yang jelas serta transparan.

4. Transparan

Semua ketentuan dan informasi mengenai pengadaan barang atau jasa, termasuk syarat teknis administrasi pengadaan, tata cara evaluasi, hasil evaluasi, penetapan calon penyedia barang atau jasa, sifatnya terbuka bagi peserta penyedia barang atau jasa yang berminat serta bagi masyarakat luas pada umumnya. 
5. Bertanggungjawab

Mencapai sasaran baik fisik, keuangan maupun manfaat bagi kelancaran pelaksanaan prinsip-prinsip dan kebijakan serta ketentuan yang berlaku dalam pengelolaan rantai suplai.

Kegiatan e-procurement tersebut tidak terlepas dari sistem informasi yang membantu dalam pengerjaan pengadaan barang/jasa, seperti yang dikemukakan oleh Jogyanto (2005:11) :

"Sistem informasi adalah suatu sistem didalam suatu organisasi yang mempertemukan kebutuhan pengolahan transaksi harian, mendukung operasi, bersifat manajerial dan kegiatan strategi dari suatu organisasi dan menyediakan pihak luar tertentu dengan laporan-laporan yang diperlukan.

\section{A.2.7. Metode Pelaksanaan e-procurement}

Dalam kegiatan e-procurement terdapat metode-metode pelaksanaannya seperti yang disebutkan oleh Willem (2012:81) yang dikutip oleh Damayanti, dkk (2014:6), yaitu:

1) e-Tendering

e-Tendering adalah tata cara pemilihan pemasok yang dilakukan secara terbuka dan dapat diikuti oleh semua pemasok yang terdaftar pada sistem pengadaan secara elektronik. 
2) e-Bidding

e-Bidding merupakan pelaksanaan pengadaan barang dan jasa dengan cara penyampaian informasi dan/atau data pengadaan dari penyedia barang dan jasa, dimulai dari pengumuman sampai dengan pengumuman hasil pengadaan, dilakukan melalui media elektronik antara lain menggunakan media internet, intranet dan/atau electronic data interchange (EDI).

3) e-Catalogue

e-Catalogue adalah sistem informasi elektronik yang memuat daftar, jenis, spesifikasi teknis dan harga barang tertentu dari berbagai penyedia barang dan jasa.

4) e-Purchasing

e-Purchasing adalah tata cara pembelian barang dan jasa melalui sarana e-Catalogue.

\section{A.3. Teori Good Governance}

\section{A.3.1. Pengertian Good Governance}

Padanan kata governance dalam bahasa Indonesia adalah penadbiran, yang berarti pemerintahan, pengelolaan (Billah, 2001). Dasar kata penadbiran adalah tadbir, dalam Kamus Besar Bahasa Indonesia (1996) berarti perihal mengurus atau mengatur (memimpin/mengelola), pemerintahan, dan administrasi. 
Sedangkan penadbir berarti pengurus atau pengelola. Kata government dalam bahasa Indonesia diterjemahkan sebagai pemerintah, dengan demikian sama maknanya dengan penadbir (Sedarmayanti, 2009: 273).

Governance lebih merupakan serangkaian proses interaksi sosial politik antara pemerintah dengan masyarakat dalam berbagai bidang yang berkaitan dengan kepentingan masyarakat dan intervensi pemerintah atas kepentingan tersebut. Sedangkan arti good dalam kepemerintahan yang baik (Good Governance) mengandung pemahaman :

a. Nilai yang menjunjung tinggi keinginan/kehendak rakyat dan nilai yang dapat meningkatkan kemampuan rakyat dalam pencapaian tujuan, kemandirian, pembangunan berkelanjutan, dan keadilan sosial.

b. Aspek fungsional dari pemerintahan yang efektif, efisien dalam pelaksanaan tugas untuk mencapai tujuan (Sedarmayanti, 2009: 274).

c. Kepemerintahan (governance) sebagaimana dikemukakan oleh Kooiman (1993) adalah governance lebih merupakan serangkaian proses interaksi sosial politik antara pemerintahan dengan masyarakat dalam berbagai bidang yang berkaitan dengan kepentingan masyarakat dan intervensi pemerintah 
atas kepentingan-kepentingan tersebut (Sedarmayanti, 2009: 273).

Secara umum, governance diartikan sebagai kualitas hubungan antara pemerintah dan masyarakat yang dilayani dan dilindunginya, private sectors (sektor swasta/ dunia usaha), dan society (masyarakat). Oleh sebab itu, Good Governance sektor publik diartikan sebagai suatu proses tata kelola pemerintahan yang baik, dengan melibatkan stakeholders terhadap berbagai kegiatan perekonomian, sosial politik, dan pemanfaatan berbagai sumber daya seperti sumber daya alam, keuangan, dan manusia bagi kepentingan rakyat yang dilaksanakan dengan menganut asas keadialan, pemerataan, persamaan, efisiensi, transparansi dan akuntabilitas (Sedarmayanti, 2007: 2).

Sedangkan OECD dan World Bank mengartikan good govenance sebagai penyelenggaraan manajemen pembangunan solid dan bertanggung jawab yang sejalan dengan demokrasi dan pasar yang efisien, penghindaran salah alokasi dana investasi yang langka, dan pencegahan korupsi secara politik dan administratif, menjalankan disiplin anggaran serta menjalankan kerangka kerja politik dan hukum bagi tumbuhnya aktivitas kewiraswastaan (Sedarmayanti, 2009: 273). 
Menurut A.H. Rahadian (2009:81) Corporate Governance pada intinya adalah mengenai suatu sistem, proses, dan seperangkat peraturan yang mengatur hubungan antara berbagai pihak yang berkepentingan (stakeholder) terutama dalam arti sempit hubungan antara pemegang saham, dewan komisaris, dan dewan direksi demi tercapainya tujuan organisasi. Corporate Governance dimaksudkan untuk mengatur hubungan-hubungan ini dan mencegah terjadinya kesalahan-kesalahan yang terjadi dapat diperbaiki segera.

A.H. Rahadian (2010:6) mengemukakan bahwa sekurangkurangnya terdapat tiga alasan yang melatarbelakangi bahwa pembaharuan pelayanan publik dapat mendorong pengembang praktik Good Governance di Indonesia. Pertama, perbaikan kinerja pemerintah, warga pengguna, dan para pelaku pasar. Kedua, pelayanan publik adalah ranah dari ketiga unsur governance melakukan interaksi yang sangat intensif. Ketiga, nilai-nilai yang selama ini mencirikan praktik good governance dapat diterjemahkan secara relatif lebih mudah dan nyata melalui pelayanan publik.

\section{A.3.2. Aktor-aktor Good Governance}

Aktor-aktor Good Governance menurut Sedarmayanti (2009: 280), antara lain : 
1. Negara/pemerintah: konsepsi kepemerintahan pada dasarnya adalah kegiatan- kegiatan kenegaraan, tetapi labih jauh dari itu melibatkan pula sektor swasta dan kelembagaan masayarakat madani. Peran pemerintah melalui kebijakan publiknya sangat penting penyimpangan yang terjadi di dalam pasar dapat dihindari. Dalam kaitannya dengan bidang pendidikan, pemerintah dan dinas- dinas yang berkaitan seperti dinas pendidikan. Negara sebagai salah satu unsur governance, di dalamnya termasuk lembaga politik dan lembaga sektor publik. Peran pemerintah melalui kebijakan publiknya sangat penting dalam memfasilitasi terjadinya mekanisme pasar yang benar sehingga penyimpangan yang terjadi di dalam pasar dapat dihindari.

2. Sektor swasta: pelaku sektor swasta mencakup perusahaan swasta yang aktif dalam interaksi dalam sistem pasar, seperti: industri pengolahan perdagangan, perbankan, koperasi termasuk kegiatan sektor informal. Dalam bidang pendidikan, sektor swasta meliputi yayasan-yayasan yang mengelola sekolah swasta.

3. Masyarakat madani: kelompok masyarakat dalam konteks kenegaraan pada dasarnya berada diantara atau di tengahtengah antara pemerintah dan perseorangan,yang mencakup baik perseorangan maupun kelompok masyarakat 
yang berinteraksi secara sosial, politik dan ekonomi. Dalam bidang pendidikan ada yang dinamakan Dewan Pendidikan yang merupakan lembaga independent yang memiliki posisi sejajar dengan Bupati/ Walikota dan DPRD.

Good Governance memungkinkan adanya kesejajaran peran antara ketiga aktor di atas. Sebagaimana dalam pengembangan kapasitas Good Governance, ada yang disebut dengan perubahan dalam distribusi kewenangan yaitu telah terjadi distribusi kewenangan yang tadinya menumpuk di pusat untuk didesentralisasikan kepada daerah, masyarakat, asosiasi dan berbagai kelembagaan yang ada di masyarakat. Artinya saat ini pemerintah bukanlah satu-satunya aktor dalam pengambilan keputusan, masyarakat dan juga pihak swasta pun berkesempatan untuk terlibat dalam pengambilan keputusan.

\section{A.3.3. Prinsip-Prinsip Good Governance}

Kepemerintahan yang baik menurut UNDP (1997) mengidentifikasi lima karakteristik yaitu :

a. Interaksi, melibatkan tiga mitra besar yaitu pemerintah, swasta, dan masyarakat madani untuk melaksanakan pengelolaan sumber daya ekonomi, sosial, dan politik.

b. Komunikasi, terdiri dari sistem jejaring dalam proses pengelolaan dan kontribusi terhadap kualitas hasil. 
c. Proses penguatan sendiri, adalah kunci keberadaan dan kelangsungan keteraturan dari berbagai situasi kekacauan yang disebabkan dinamika dan perubahan lingkungan, memberi kontribusi terhadap partisipasi dan menggalakkan kemandirian masyarakat, dan memberikan kesempatan untuk kreativitas dan stabilitas berbagai aspek kepemerintahan yang baik.

d. Dinamis, keseimbangan berbagai unsur kekuatan kompleks yang menghasilkan persatuan, harmoni, dan kerja sama untuk pertumbuhan dan pembangunan berkelanjutan, kedamaian dan keadilan, dan kesempatan merata untuk semua sektor dalam masyarakat madani.

e. Saling ketergantungan yang dinamis antara pemerintah, kekuatan pasar, dan masyarakat madani.

Lima karakteristik dalam Good Governance mencerminkan terjadinya proses pengambilan keputusan yang melibatkan stakeholders dengan menerapkan prinsip good governance yaitu partisipasi, transparansi, berorientasi kesepakatan, kesetaraan, efektif dan efisien, akuntabilitas, serta visi dan misi. Sedangkan Lembaga Administrasi Negara (LAN) (2003) mengungkapkan prinsip-prinsip good governance antara lain yaitu akuntabilitas, transparansi, kesetaraan, supremasi hukum,keadilan, partisipasi, desentralisasi, kebersamaan, profesionalitas, cepat 
tanggap, efektif dan efisien, dan berdaya saing. Mustopadidjaja (2003) mengatakan prinsip-prinsip Good Governance adalah demokrasi dan pemberdayaan, pelayanan, transparansi dan akuntabiiltas, partisipasi, kemitraan, desentralisasi, dan konsistensi kebijakan dan kepastian hukum (Sedarmayanti, 2009:282-287).

Jumlah komponen ataupun prinsip yang melandasi tata pemerintahan yang baik sangat bervariasi dari satu institusi ke institusi lain, dari satu pakar ke pakar lainnya. Namun paling tidak ada sejumlah prinsip yang dianggap sebagai prinsip- prinsip utama yang melandasi Good Governance, yaitu akuntabilitas, transparansi, dan partisipasi (Sedarmayanti, 2009:289).

Public Private Partnership adalah salah satu jenis Privatisasi yang diartikan pengaturan di mana pemerintah memerlukan insentif modal, kebutuhan akan infrastruktur dengan masa pakai jangka panjang, dan kombinasi pembiayaan pembangunan fasilitas yang diinginkan antara pemerintah dengan swasta (sebagian besar biaya biasanya dibiayai oleh swasta).

Menurut Mary Ismowati (2016:146) mengemukakan bahwa tujuan Public Private Partnerships adalah untuk meningkatkan kemampuan pemerintah dalam pelayanan kepada masyarakat baik dalam kualitas dan kuantitas dengan cara menambah modal, menangani resiko bersama dengan lebih efisien. 


\section{A.3.4. Kendala Mewujudkan Good Governance}

Upaya perbaikan sistem birokrasi belum berjalan sesuai dengan tuntutan masyarakat. Hal tersebut terkait dengan tingginya kompleksitas dalam mencari solusi perbaikan. Demikian pula masih tingginya tingkat penyalahgunaan wewenang, banyaknya praktik $\mathrm{KKN}$, dan masih lemahnya pengawasan terhadap kinerja aparatur negara merupakan cerminan kondisi kinerja birokrasi yang masih jauh dari harapan. Banyaknya permasalah birokrasi tersebut belum sepenuhnya teratasi, baik dari sisi internal maupun eksternal (Sedarmayanti, 2009: 310-311).

Dari sisi internal, faktor demokrasi dan desentralisasi telah membawa dampak pada proses pengambilan keputusan kebijakan publik. Dampak tersebut terkait dengan makin meningkatnya tuntutan akan partisipasi masyarakat dalam kebijakan publik, meningkatnya tuntutan penerapan prinsip tata kepemerintahan yang baik antara lain transparansi, akuntabilitas, dan kualitas kinerja publik serta taat hukum. Secara khusus dari sisi internal birokrasi, berbagai permasalahan masih banyak yang dihadapi, antara lain pelanggaran disiplin, penyalahgunaan kewenangan, dan banyaknya praktik KKN. Dari sisi eksternal, faktor globalisasi dan revolusi teknologi informasi (e-government) merupakan tantangan tersendiri dalam upaya menciptakan pemerintahan yang bersih, baik, dan berwibawa. Hal tersebut terkait dengan makin meningkatnya ketidakpastian akibat 
perubahan faktor lingkungan politik, ekonomi, dan sosial yang terjadi dengan cepat (Sedarmayanti, 2009: 310-311

Selain itu, problem demokrasi dari segi lembaga dan perilaku individu masih muncul. Rakyat masih belum merasa terwakili oleh keberadaan wakilnya di DPR(D) karena partisipasinya hanya pada saat pemilu, setelah itu rakyat ditinggal dalam proses pengambilan kebijakan. Rendahnya partisipasi dalam masyarakat mengurangi tingkat legitimasi pemerintah sehingga munculnya pemerintahan yang kuat ditingkat lokal maupun pusat masih dalam cita-cita (Nugroho, 2001 dalam Sedarmayanti, 2009: 311).

\section{A.4. Teori Kinerja Lembaga}

Kinerja seseorang dapat dilihat dengan cara membandingkan standar yang telah ditetapkan versus realisasi yang telah dicapai. Hal ini seperti tampak pada konstatasi Sayle \& Strauss dalam Wibowo (2007:58) yang menyatakan:

"In effect, the standard established a target, and at the end of the target periode (week, month, year) both manager and boss can compare the expected standard of performance with actual level of achievement."

Kinerja adalah kegiatan yang paling lazim dinilai dalam suatu organisasi, yakni bagaimana ia melakukan segala sesuatu yang berhubungan dengan suatu pekerjaan, jabatan, atau peranan dalam organisasi. Standar kinerja diperlukan karena dua alasan. Pertama, membimbing perilaku pekerja untuk menyelesaikan 
standar yang telah dibangun. Apabila manajer menciptakan standar kinerja dengan pekerja dan memperjelas apa yang diharapkan, hal tersebut akan merupakan latihan yang berharga. Hal ini karena orang menginginkan melakukan pekerjaan yang dapat diterima.

Kedua, menyediakan dasar bagi kinerja pekerja dapat dinilai secara efektif dan jujur. Sampai standar kinerja dibuat, penilaian sering bias terhadap perasaan dan evaluasi subyektif. Tanpa memandang pendekatan dan bentuk yang digunakan dalam program review kinerja dan penilaian, proses klarifikasi dari apa yang diharapkan merupakan hal yang penting jika program berjalan efektif. Standar kinerja merupakan cara terbaik untuk melakukannya.

Kinerja pegawai pada dasarnya terbentuk setelah pegawai merasa adanya kepuasan, karena kebutuhannya terpenuhi dengan kata lain apabila kebutuhan pegawai belum terpenuhi sebagaimana mestinya maka kepuasan kerja tidak akan tercapai, dan pada hakikatnya kinerja pegawai akan sulit terbentuk. Setiap orang yang bekerja digerakan oleh suatu motif. Motif pada dasarnya bersumber pertama-tama berbagai kebutuhan dasar individu atau dapat dikatakan bahwa kekuatan yang memotivasi seorang untuk bekerja giat dalam pekerjaanya tergantung dari hubungan timbal balik antar apa yang diinginkan atau dibutuhkan dari hasil pekerjaan tersebut dan seberapa besar keyakinan organisasi akan memberikan 
kepuasan bagi keinginannya sebagai imbalan atas usaha yang dilakukannya.

Menurut Hasibuan (2006:78) kinerja merupakan suatu hasil kerja yang dicapai seseorang dalam melaksanakan tugas-tugas yang dibebankan kepadanya yang didasarkan atas kecakapan, pengalaman, dan kesungguhan serta waktu.

Menurut Simamora (2007:144) kinerja karyawan (employee performance) adalah tingkat terhadap mana para karyawan mencapai persyaratan-persyaratan pekerjaaan. Untuk meningkatkan kinerja, biasanya manajemen menggunakan teknik penilaian (appraisal).

Pada organisasi modern, penilaian memberikan mekanisme penting bagi manajemen untuk digunakan dalam menjelaskan tujuan-tujuan dan standar-standar kinerja dan untuk memotivasi kinerja individu di waktu berikutnya.

Menurut Mangkunegara (2007:76) kinerja adalah hasil kerja secara kuantitas dan kualitas yang dicapai oleh seseorang pegawai dalam melaksanakan tugasnya sesuai dengan tanggung jawab yang diberikan kepadanya.

Menurut Wibowo (2007:59) Standar kinerja merupakan elemen penting dan sering dilupakan dalam proses review kinerja. Standar kinerja menjelaskan apa yang diharapkan manajer dari pekerja sehingga harus dipahami pekerja. Kualifikasi tentang apa yang diharapkan merupakan hal yang penting untuk memberi pedoman perilaku pekerja dan dipergunakan sebagai dasar untuk penilaian. 
Dari pengertian ini standar kinerja merupakan tolok ukur terhadap mana kinerja diukur agar efektif. Standar kinerja harus dihubungkan dengan hasil yang diinginkan dari setiap pekerjaan.

Terdapat perbedaan pendapat di antara para ahli tentang arti standar kinerja. Wibowo (2007:61) menggunakan definisi sebagai "kondisi yang akan terjadi ketika segmen pekerjaan dikerjakan dengan baik," sementara yang lainnya menggunakan definisi "kondisi yang akan terjadi ketika segmen pekerjaan dikerjakan dengan cara yang dapat diterima".

Kinerja pegawai yaitu penampilan hasil karya pegawai baik kuantitas maupun kualitas dalam suatu organisasi. Penampilan hasil karya tidak terbatas kepada pegawai yang memangku jabatan fungsional maupun struktural, tetapi juga kepada keseluruhan jajaran pegawai di dalam organisasi. Dimensi kinerja pegawai menurut Gery Dessler (2004:57) meliputi : a. kualitas kerja (quality of output); b. kuantitas kerja (quantity of output); c. jumlah waktu kerja (time of work); d. kerjasama (corporation); e. supervisi (supervision).

Menurut Kirkpatrick dalam Wibowo (2007:71), terdapat delapan karakterisitik yang membuat suatu standar kinerja efektif, yaitu sebagai berikut: didasarkan pada pekerjaan, dapat dicapai, dapat dipahami, disepakati, spesifik dan sedapat mungkin terukur, berorientasi pada waktu, harus tertulis, dan dapat berubah.

Mondy dkk (1998:155) mengidentifikasi lima standar yang dapat digunakan untuk melihat kinerja pegawai, yaitu: 
a) Time standards. Time standards state the length of time it should take to make a certain product or perform a certain service.

b) Productivity standards. These standards are based on the amount of product or service produced during a set time period.

c) Cost standards. These standards are based on the cost associated with producing the goods or service.

d) Quality standards. These are based on the level of perfection desired.

e) Behavioral standards. These are based on type of behavior desired of workers in the organization.

Selain dengan faktor-faktor tersebut, menurut Furtwengler dalam Mangkunegara (2007:141-143), untuk melihat prestasi kerja karyawan dapat dilihat melalui aspek-aspek berikut:

a. Kecepatan

Kecepatan yang dimaksud dalam hal ini adalah kecepatan pegawai dalam menyelesikan tugas-tugasnya. Kecepatan sangatlah penting bagi keunggulan bersaing perusahaan.

b. Kualitas

Kualitas dapat dipandang sebagai kemampuan karyawan untuk bekerja sesuai dengan tuntutan perusahaan atau pelanggan. 
c. Layanan

Faktor layanan terkait dengan kemampuan seorang karyawan untuk memenuhi kebutuhan pelanggannya atau konsumen yang umumnya dilakukan untuk perusahaan-perusahaan jasa.

d. Nilai

Faktor nilai tercermin dari tindakan karyawan dalam menjalankan setiap aktivitas yang menjadi tanggung jawabnya di perusahaan.

e. Keterampilan interpersonal

Faktor keterampilan interpersonal terkait dengan kamampuan karyawan untuk menjalin hubungan dengan sesama karyawan.

f. Mental untuk sukses

Mental untuk sukses terkait dengan sikap optimisme karyawan dalam menjalankan pekerjaan dan juga berkenaan dengan usaha-usaha yang dilakukan karyawan dalam menyelesaikan apa yang menjadi tanggung jawabnya.

g. Terbuka untuk berubah

Keterbukaan untuk berubah merupakan suatu sikap untuk mau menerima atau mau berusaha melakukan suatu perubahan dalam dirinya atau lingkungan kerjanya demi suatu perbaikan.

h. Kreativitas

Kreativitas adalah kemampuan atau kekuatan untuk menciptakan sesuatu hal yang baru, yang ditandai dengan 
kemampuan untuk melakukan investasi dalam bentuk baru dan kemampuan untuk menghasilkan gagasan secara terus menerus.

i. Keterampilan berkomunikasi

Komunikasi menjadi salah satu aktivitas organisasi yang tidak bisa diabaikan dan senantiasa mendominasi dalam setiap aktivitas organisasi.

j. Inisiatif

Inisiatif merupakan kemauan untuk melakukan suatu hal berdasarkan kesadaran sendiri dan tanpa harus melalui perintah atau tekanan dari orang lain.

k. Perencanaan organisasi

Perencanaan merupakan langkah awal yang mesti dilakukan oleh setiap individu ataupun organisasi sebelum melakukan aktivitas.

Menurut Suprihanto (2007:47) dapat mengacu pada kesetiaan, prestasi kerja, tanggung jawab, ketaatan, kejujuran, kerja sama, prakarsa dan kepemimpinan.

1. Kesetiaan :

lalah tekad dan kesanggupan mentaati, melaksanakan dan mengamalkan sesuatu yang ditaati dengan penuh kesadaran dan tanggung jawab. 
2. Prestasi Kerja

lalah suatu hasil kerja yang secara nyata dapat dicapai oleh seorang pegawai dalam melaksanakan tugas yang dibebankan kepadanya.

3. Tanggung Jawab

lalah kesanggupan seorang pegawai untuk menyelesaikan pekerjaan yang diserahkan kepadanya dengan sebaik-baiknya dan tepat pada waktunya serta berani memikul resiko atas keputusan yang diambilnya atau tindakan yang dilakukannya.

4. Ketaatan

lalah kesanggupan seorang pegawai untuk mentaati segala peraturan perundang-undangan dan peraturan kedinasan yang berlaku, mentaati perintah kedinasan yang diberikan oleh atasan yang berwenang serta kesanggupan untuk tidak melanggar larangan yang ditentukan.

5. Kejujuran

lalah ketulusan hati seorang pegawai dalam melaksanakan tugas dan kemampuan untuk tidak menyalahgunakan wewenang yang diberikan kepadanya.

6. Kerja sama

lalah kemampuan seorang pegawai untuk bekerja bersamasama dengan orang lain dalam menyelesaikan sesuatu tugas 
yang ditentukan, sehingga mencapai daya guna dan hasil guna yang sebesar-besarnya.

7. Prakarsa

lalah kemampuan seorang pegawai untuk mengambil keputusan, langkah-langkah atau melaksanakan sesuatu tindakan yang diperlukan dalam melaksanakan tugas pokok tanpa menunggu perintah dari atasan.

8. Kepemimpinan

lalah kemampuan seorang pegawai untuk meyakinkan orang lain sehingga dapat dikerahkan secara maksimal untuk melaksanakan tugas pokoknya. Penilaian unsur kepemimpinan hanya dikenakan bagi pegawai yang berpangkat Pengatur Muda golongan ruang $\mathrm{II} / \mathrm{a}$ ke atas yang memangku suatu jabatan.

Standar-standar atau aspek-aspek tersebut dapat dimanfaatkan dan dijadikan kriteria atau parameter untuk melihat kinerja pegawai dalam suatu organisasi, baik organisasi bisnis maupun organisasi pemerintahan.

Ada beberapa definisi atas batasan mengenai kinerja atau job preformance, sebagaimana dikutip oleh As'ad dalam bukunya Pshikologi Industri (1995:47-48) Job performance ialah seccesful role achievement yang diperoleh seseorang dari perbuatannya. Dari batasan-batasan tersebut jelaslah bahwa yang dimaksud 
dengan Job Performance adalah hasil yang dicapai oleh seseorang menurut ukuran yang berlaku untuk pekerjaan yang bersangkutan. Tingkat keberhasilan seseorang di dalam melaksanakan tugas pekerjannya dinamakan level of performance. Orang yang level of permormance-nya tinggi dikatakan orang yang produktif, sedang orang yang level of performance-nya tindak mencapai standar disebut tidak produktif atau performance-nya rendah.

Kinerja suatu organisasi, baik organisasi yang berorientasikan mencari keuntungan maupun organisasi pemerintahan atau organisasi sosial atau organisasi keagamaan tergantung kepada etos kerja dari peserta organisasi bersangkutan.

Dalam konteks sikap mental aparat pemerintah, maka kinerja individu pegawai juga dipengaruhi oleh kualitas moral yang dimiliki tiap individu tersebut. Saefullah (2005:99) mengemukakan bahwa, kualitas moral merupakan penyokong (bahkan melandasi) sikap mental, berisi kebajikan yang terdiri dari sabar, jujur, loyal, sopan, hemat, rendah hati dan sebagainya.

Menurut Mary Ismowati (2018:141) Faktor pendukung yang berpengaruh langsung terhadap mutu pelayanan yang diberikan, adalah faktor manusia yang memberikan pelayanan tersebut. Manusia/pegawai (Customer Service Officer) yang melayani masyarakat harus memiliki kemampuan melayani pelanggan secara tepat dan cepat. Disamping itu, Customer Service Officer 
harus memiliki kemampuan dalam berkomunikasi, sopan santun, ramah, dan bertanggung jawab penuh terhadap yang dilayaninya.

Kelembagaan menurut Uphoff (1992) dan Fowler (1992) adalah "a complex of norm and behavior that persist overtime by serving some socially valued purpose" sedangkan organisasi adalah struktur peran yang diakui dan diterima. Mengacu pada konsep kelembagaan yang diajukan oleh Gilin dan Gilin (1954) tentang tingkat kemantapan tertentu dari kelembagaan, Horton dan Hunt (1984) tentang rutinisasi dari kelembagaan, dan Uphoff (1986) dalam Saptana (2006) yang menyatakan bahwa :

"Kelembagaan sebagai pola perilaku yang stabil, dihargai dan berlaku dalam waktu yang lama, maka bagian pokok lainnya yang penting untuk diperhatikan dalam pembahasan mengenai kinerja kelembagaan adalah tentang pola perilaku atau pola interaksi yang terjalin antar pelaku dalam suatu kelembagaan".

Kata kelembagaan merujuk kepada sesuatu yang bersifat mantap yang hidup di dalam masyarakat (Koentjaraningrat 1997). Secara konseptual, kelembagaan berasal dari istilah pranata yang mengandung pengertian sebagai padanan institution dan pranata sosial sebagai social institution. Suatu kelembagaan adalah suatu pemantapan perilaku yang hidup pada suatu kelompok orang. Kelembagaan merupakan sesuatu yang stabil, mantap, dan berpola, berfungsi untuk tujuantujuan tertentu dalam masyarakat, ditemukan dalam sistem sosial tradisional dan modern atau bisa 
berbentuk tradisional dan modern, dan berfungsi untuk mengefisienkan kehidupan sosial.

Menurut Pakpahan (1989) dalam Elizabeth (2010), suatu kelembagaan dicirikan oleh tiga hal utama, yaitu: (1) yurisdiction of boundary (batas yurisdiksi), (2) property right (hak kepemilikan), (3) rule of representation (aturan representasi). Perubahannya menghasilkan performance yang diinginkan, dan ditentukan oleh: (1) sense of community (perasaan sebagai satu masyarakat), (2) eksternalitas, (3) homogenitas, dan (4) economic of scale (skala ekonomi). Tiap kelembagaan memiliki tujuan tertentu, dan orangorang yang terlibat di dalamnya memiliki pola perilaku tertentu serta nilai-nilai dan norma-norma yang sudah disepakati yang sifatnya khas. Tiap kelembagaan dibangun untuk satu fungsi tertentu. Karena itu kita mengenal kelembagaan pendidikan, kelembagaan ekonomi, agama, dan lain-lain. Jadi, dunia berisi kelembagaankelembagaan dan manusia pasti masuk kelembagaan tersebut (Sudaryanto 2005).

Salah satu ciri umum kelembagaan adalah adanya suatu tingkat kekekalan atau kemapanan (Gilin dan Gilin 1954 dalam Saptana 2006) sehingga aturan main dalam suatu kelembagaan juga telah berlaku dalam waktu yang cukup lama, dan mungkin masih akan berlaku dalam jangka waktu yang lama lagi. Namun jika mengacu pada pendapat Granovetter dan Swedberg (1992) yang 
menyatakan bahwa kelembagaan ekonomi dikonstruksikan secara sosial, maka juga tidak tertutup kemungkinan adanya konstruksi ulang mengenai aturan main yang berlaku. Mengacu pada pendapat di atas, maka pembahasan mengenai aturan main dalam kelembagaan ini akan mencakup tentang aturan main itu sendiri dan perubahan-perubahan yang terjadi pada aturan main, serta bagaimana dan oleh siapa aturan main tersebut dikonstruksi.

Pada intinya, kelembagaan adalah jejaring yang terbentuk dari sejumlah, mungkin puluhan sampai ratusan interaksi atau bisa disebut kelembagaan sebagai interaksi yang berpola. Dari interaksi inilah dapat dipahami sebuah kelembagaan hanya dengan memahami bagaimana pola, ciri, dan bentuk sebuah interaksi dan dalam satu kelembagaan, sebagian besar interaksi berbentuk sama.

Dalam proses pengembangan kelembagaan, beberapa prinsip ini perlu dijadikan pegangan (Sudaryanto 2005), yaitu:

- Pahami setting masyarakat setempat, karakteristik dan konfigurasi ekonomi, politik, dan sosial setempat, serta level kolektivitas dan individualitasnya.

- Bidang pekerjaan yang akan dilakukan, jenis, dan sifat interaksi yang ada di dalamnya, serta adanya motivasi sosial dan ekonomi yang tercampur didalamnya. 
- Pelajari kelembagaan yang sudah ada di masyarakat, aktivitas yang akan dijalankan, manfaat, dan masalah yang ada.

- Kelompokkan basis kelembagaan yang sesuai untuk tiap aktivitas yang akan dijalankan, kecocokan, pola komunitas, pola pasar, pola pemerintah, dan basis pelayanan.

- Pahami pula kekentalan kelembagaan yang sesungguhnya diperlukan, penguatan personal relation, personal network, dan organisasi.

Kriteria kelembagaan untuk tujuan praktis yang dihubungkan dengan pembentukan kelembagaan urutannya sebagai berikut (Suradisastra 2009) :

1. Terorganisir dan memiliki norma atau aturan yang ditegakkan.

2. Memiliki cita-cita atau tujuan yang ingin dicapai.

3. Secara konsisten melakukan suatu fungsi secara berulang dan telah dilakukan dalam jangka cukup lama.

4. Melakukan interaksi dengan lembaga lain sebagai manifestasi saling ketergantungan antar lembaga.

Kinerja lembaga adalah suatu usaha yang dilakukan oleh lembaga dalam rangka untuk mencapai prestasi yang lebih baik, baik berupa hasil kerja maupun proses kerjanya. Adapun dimensi dari kinerja lembaga menurut Muhaimin (2010:374) terdiri dari : 1) Konteks; 2) Input; 3) Proses; 4) Output; dan 5) Outcame. 


\section{A.5. Penelitian Terdahulu}

Landasan penelitian terdahulu digunakan sebagai referensi atau acuan untuk menunjang keakuratan data penelitian yang dilakukan peneliti dalam menyelesaikan penelitian ini. Landasan penelitian terdahulu menjadi hal yang sangat penting bagi peneliti dalam memilih dan menentukan teori yang akan digunakan dan juga memilih variabel yang tepat dalam penelitian ini.

Untuk penelitian terdahulu yang terkait dengan pengaruh Penerapan Electronic Procurement dan Good Governance terhadap Kinerja Pengadaan Barang/Jasa pada Pemerintah Kabupaten Pandeglang dapat diuraikan sebagai berikut :

Pertama, penelitian yang dilakukan oleh A.h. Rahadian Dan Irman Gapur (2015) yang meneliti tentang Pengaruh Sistem EProcurement Dan Kompetensi Terhadap Kinerja Kantor Layanan Pengadaan Barang /Jasa Kabupaten Bogor. Penelitian ini menggunakan metode explanatory kuantitatif untuk mengetahui seberapa besar pengaruh variabel bebas dan variabel terikat secara parsial dan berganda. Berdasarkan hasil pengolahan data di peroleh hasil terdapat pengaruh positif dan signifikan Sistem eProcurement terhadap Kinerja Kantor Layanan Pengadaan Barang /Jasa Kabupaten Bogor, terdapat pengaruh positif dan signifikan Kompetensi terhadap Kinerja Kantor Layanan Pengadaan Barang /Jasa Kabupaten Bogor, dan terdapat pengaruh 
positif dan signifikan Sistem e-Procurement dan Kompetensi secara bersama-sama terhadap Kinerja Kantor Layanan Pengadaan Barang /Jasa Kabupaten Bogor.

Kedua, penelitian yang dilakukan Sulistyowati (2017) dengan judul "Pengaruh Good Corporate Governance Terhadap Kinerja Keuangan Pada Perusahaan Perbankan". Jenis penelitian yang dilakukan oleh peneliti adalah penelitian korelasional (Correlational Research). Hasil penelitian ini menunjukkan bahwa :

(1) Dewan direksi berpengaruh positif terhadap kinerja keuangan.

(2) Dewan komisaris berpengaruh posifif terhadap kinerja keuangan. (3) Komisaris independen tidak berpengaruh terhadap kinerja keuangan. (4) Komite audit tidak berpengaruh terhadap kinerja keuangan.

Ketiga, Penelitian yang dilakukan oleh Maria Rofina (2013) dengan judul "Pengaruh Penerapan Good Corporate Governance Terhadap Kinerja Keuangan Perusahaan Di BEl". Metode penelitian menggunakan analisis regresi linier sederhana dengan analisis statistik yang berupa uji statistik t. Hasil penelitian menunjukkan bahwa secara parsial penerapan good corporate governance berpengaruh terhadap net profit margin, penerapan good corporate governance berpengaruh terhadap return on investment, dan penerapan good corporate governance berpengaruh terhadap return on equity. 
Keempat, penelitian dilakukan oleh Mahardika lintangsari, Dini Wahyu Hapsari, Eddy Budiono (2017) dengan judul "The Effect of E-Procurement Implementation, Internal Control of Preventing Fraud (Empirical Study on PT. PLN (Persero) Distribution West Java and Banten)". The research data is analyzed by using descriptive statistical analysis, validity and reliability test, classic assumption test, multiple linear regression analysis. The result of the study shows that the implementation of e-procurement, internal control system, and prevention fraud in PT.PLN (Persero) Distribution West Java and Banten are in a good category. Based on the hypothesis test, the result shows that the implementation of e-procurement, and internal control, partially has significant effect for prevention fraud. Simultaneously, the implementation of eprocurement, and internal control significantly effects for prevention fraud in PT. PLN (Persero) Distribution West Java and Banten.

Kelima, penelitian oleh Lisa Oktaviani (2017) dengan judul "The Effect of E-Procurement Against the Prevention and Detection of Fraud in the Public Sector procurement carried out in SKPD city of Padang, Solok, Pesisir Selatan". The research data is analyzed by using descriptive statistical analysis. The results of research partially is where the planning stage, and the stage of preparation of tender documents was effect on the prevention of procurement fraud, as weel as on the stage of the auction refutation influence the 
detection fraud procurement. While the variable stage of formation of the committee, the prequalification phase, evaluation stage, the bidding stage, the phase announcement of auction no significant effect on procurement fraud prevention and detection.

Keenam, penelitian yang dilakukan oleh Andri Veno (2015) dengan judul "The Influence of Good Corporate Governance toward Corporate Performance of Corporate Manufacture Go Public. The method analysis of this research using multiple regression. Results from this research show that (1) The size of the council of directors significant positive effect to the corporate performance, (2) Independent council commissioner wasn't significant effect to corporate performance (3) the total of council commissioner wasn't significant effect to corporate performance (4) Audit Committee significant positive effect to corporate performance (5) Simultan, Size of the directors council, Independent of the commissioners council, the total of commissioners council and the Audit Committee had a significant effect to the corporate performance. Untuk lebih jelasnya dapat dilihat pada tabel berikut ini : 
Tabel 2.1.

Penelitian Terdahulu

\begin{tabular}{|c|c|c|c|}
\hline No & $\begin{array}{c}\text { Judul, Penulis dan } \\
\text { Tahun }\end{array}$ & $\begin{array}{c}\text { Metode } \\
\text { Penelitian }\end{array}$ & Hasil Penelitian \\
\hline 1 & $\begin{array}{l}\text { Pengaruh Sistem E- } \\
\text { Procurement Dan } \\
\text { Kompetensi Kinerja } \\
\text { Terhadap Layanan } \\
\text { Kantor Kabupaten } \\
\text { Pengadaan Barang } \\
\text { /Jasa Kabuan } \\
\text { Bogor. } \\
\text { A.h. Rahadian Dan } \\
\text { Irman Gapur (2015) }\end{array}$ & $\begin{array}{l}\text { Explanatory } \\
\text { kuantitatif untuk } \\
\text { mengetahui } \\
\text { seberapa besar } \\
\text { pengaruh } \\
\text { variabel bebas } \\
\text { dan rariabel } \\
\text { terikat secara } \\
\text { parsial dan } \\
\text { berganda }\end{array}$ & $\begin{array}{l}\text { Terdapat pengaruh positif dan } \\
\text { signifikan Sistem terhadap } \\
\text { Procurement Kantor Layanan } \\
\text { Kinerja Karang /Jasa } \\
\text { Pengadaan Baran } \\
\text { Kabupaten Bogor, terdapat } \\
\text { pengaruh positif dan signifikan } \\
\text { Kompetensi terhadap Kinerja } \\
\text { Kantor Layanan Pengadaan } \\
\text { Barang /Jasa Kabupaten } \\
\text { Bogor, dan terdapat pengaruh } \\
\text { positif dan signifikan Sistem e- } \\
\text { Procurement dan Kompetensi } \\
\text { secara bersama-sama } \\
\text { terhadap Kinerja Kantor } \\
\text { Layanan Pengadaan Barang } \\
\text { /Jasa Kabupaten Bogor. }\end{array}$ \\
\hline 2 & $\begin{array}{l}\text { Pengaruh Good } \\
\text { Corporate } \\
\text { Governance } \\
\text { Terhadap Kinerja } \\
\text { Keuangan Pada } \\
\text { Perusahaan } \\
\text { Perbankan. } \\
\text { Sulistyowati (2017) }\end{array}$ & $\begin{array}{l}\text { penelitian } \\
\text { korelasional } \\
\text { (Correlational } \\
\text { Research) }\end{array}$ & $\begin{array}{l}\text { (1) Dewan direksi } \\
\text { berpengaruh positif terhadap } \\
\text { kinerja keuangan. (2) Dewan } \\
\text { komisaris berpengaruh posifif } \\
\text { terhadap kinerja keuangan. } \\
\text { (3) Komisaris independen } \\
\text { tidak berpengaruh terhadap } \\
\text { kinerja keuangan. (4) Komite } \\
\text { audit tidak berpengaruh } \\
\text { terhadap kinerja keuangan. }\end{array}$ \\
\hline 3 & $\begin{array}{l}\text { Pengaruh } \\
\text { Penerapan Good } \\
\text { Corporate } \\
\text { Governance } \\
\text { Terhadap Kinerja } \\
\text { Keuangan } \\
\text { Perusahaan Di BEI. } \\
\text { Maria Rofina (2013) }\end{array}$ & $\begin{array}{l}\text { Analisis statistik } \\
\text { berupa uji } \\
\text { statistik t }\end{array}$ & $\begin{array}{l}\text { Penerapan good corporate } \\
\text { governance berpengaruh } \\
\text { terhadap net profit margin, } \\
\text { penerapan good corporate } \\
\text { governance berpengaruh } \\
\text { terhadap return on } \\
\text { investment, dan penerapan } \\
\text { good corporate governance } \\
\text { berpengaruh terhadap return } \\
\text { on equity. }\end{array}$ \\
\hline
\end{tabular}


Lanjutan Tabel 2.1

\begin{tabular}{|c|c|c|c|}
\hline 4 & $\begin{array}{l}\text { The Effect of E- } \\
\text { Procurement } \\
\text { Implementation, } \\
\text { Internal Control of } \\
\text { Preventing Fraud } \\
\text { (Empirical Study on } \\
\text { PT. PLN (Persero) } \\
\text { Distribution West } \\
\text { Java and Banten). } \\
\text { Mahardika } \\
\text { lintangsari, Dini } \\
\text { Wahyu Hapsari, } \\
\text { Eddy Budiono } \\
\text { (2017) }\end{array}$ & $\begin{array}{l}\text { The research } \\
\text { data is analyzed } \\
\text { by using } \\
\text { descriptive } \\
\text { statistical } \\
\text { analysis, validity } \\
\text { and reliability } \\
\text { test, classic } \\
\text { assumption test, } \\
\text { multiple linear } \\
\text { regression } \\
\text { analysis }\end{array}$ & $\begin{array}{l}\text { The result of the study shows } \\
\text { that the implementation of e- } \\
\text { procurement, internal control } \\
\text { system, and prevention fraud } \\
\text { in PT.PLN (Persero) } \\
\text { Distribution West Java and } \\
\text { Banten are in a good } \\
\text { category. Based on the } \\
\text { hypothesis test, the result } \\
\text { shows that the implementation } \\
\text { of e-procurement, and internal } \\
\text { control, partially has } \\
\text { significant effect for } \\
\text { prevention fraud. } \\
\text { Simultaneously, the } \\
\text { implementation of e- } \\
\text { procurement, and internal } \\
\text { control significantly effects for } \\
\text { prevention fraud in PT. PLN } \\
\text { (Persero) Distribution West } \\
\text { Java and Banten. }\end{array}$ \\
\hline 5 & $\begin{array}{l}\text { The Effect of E- } \\
\text { Procurement } \\
\text { Against the } \\
\text { Prevention and } \\
\text { Detection of Fraud } \\
\text { in the Public Sector } \\
\text { procurement carried } \\
\text { out in SKPD city of } \\
\text { Padang, Solok, } \\
\text { Pesisir Selatan. } \\
\text { Lisa Oktaviani } \\
\text { (2017) }\end{array}$ & $\begin{array}{l}\text { The research } \\
\text { data is analyzed } \\
\text { by using } \\
\text { descriptive } \\
\text { statistical } \\
\text { analysis }\end{array}$ & $\begin{array}{l}\text { The results of research } \\
\text { partially is where the planning } \\
\text { stage, and the stage of } \\
\text { preparation of tender } \\
\text { documents was effect on the } \\
\text { prevention of procurement } \\
\text { fraud, as weel as on the stage } \\
\text { of the auction refutation } \\
\text { influence the detection fraud } \\
\text { procurement. While the } \\
\text { variable stage of formation of } \\
\text { the committee, the } \\
\text { prequalification phase, } \\
\text { evaluation stage, the bidding } \\
\text { stage, the phase } \\
\text { announcement of auction no } \\
\text { significant effect on } \\
\text { procurement fraud prevention } \\
\text { and detection. }\end{array}$ \\
\hline
\end{tabular}




\section{Lanjutan Tabel 2.1}

\begin{tabular}{|c|c|c|c|}
\hline 6 & $\begin{array}{l}\text { The Influence of } \\
\text { Good Corporate } \\
\text { Governance toward } \\
\text { Corporate } \\
\text { Performance of } \\
\text { Corporate } \\
\text { Manufacture Go } \\
\text { Public. } \\
\text { Andri Veno (2015). }\end{array}$ & $\begin{array}{l}\text { The method } \\
\text { analysis of this } \\
\text { research using } \\
\text { multiple } \\
\text { regression. }\end{array}$ & $\begin{array}{l}\text { Results from this research } \\
\text { show that (1) The size of the } \\
\text { council of directors significant } \\
\text { positive effect to the corporate } \\
\text { performance, (2) Independent } \\
\text { council commissioner wasn't } \\
\text { significant effect to corporate } \\
\text { performance (3) the total of } \\
\text { council commissioner wasn't } \\
\text { significant effect to corporate } \\
\text { performance (4) Audit } \\
\text { Committee significant positive } \\
\text { effect to corporate } \\
\text { performance (5) Simultan, } \\
\text { Size of the directors council, } \\
\text { Independent of the } \\
\text { commissioners council, the } \\
\text { total of commissioners council } \\
\text { and the Audit Committee had } \\
\text { a significant effect to the } \\
\text { corporate performance. }\end{array}$ \\
\hline
\end{tabular}

Perbedaan dari hasil penelitian terdahulu dengan penelitian yang akan diteliti adalah lokasi penelitian yang berbeda. Dimana lokasi yang akan diteliti oleh penulis terletak di Pemerintah Kabupaten Pandeglang. Adapun untuk persamaan penelitian terdahulu dengan penelitian yang akan diteliti adalah sama-sama menggunakan variabel terikat yang sama yaitu tentang kinerja pegawai dan terdapat kesamaan pada variabel bebas. 
B. Kerangka Konseptual dan Model Penelitian

B.1. Pengaruh Penerapan Electronic Procurement dan Good Governance Terhadap Kinerja Pengadaan Barang/Jasa pada Bagian Pengadaan Barang dan Jasa Sekretariat Daerah Kabupaten Pandeglang.

Kinerja berasal dari kata job performance atau actual performance yang berarti prestasi kerja atau prestasi sesungguhnya yang dicapai oleh seseorang. Pengertian kinerja (prestasi kerja) adalah hasil kerja secara kualitas dan kuantitas yang dicapai oleh seorang pegawai dalam melaksanakan fungsinya sesuai dengan tanggung jawab yang diberikan kepadanya.

Kinerja lembaga adalah suatu usaha yang dilakukan oleh lembaga dalam rangka untuk mencapai prestasi yang lebih baik, baik berupa hasil kerja maupun proses kerjanya. Adapun dimensi dari kinerja lembaga menurut Muhaimin (2010:374) terdiri dari : 1) Konteks; 2) Input; 3) Proses; 4) Output; dan 5) Outcame.

Kinerja pengadaan barang/jasa dipengaruhi oleh faktor Penerapan Electronic Procurement. Willem (2012:11) yang menyatakan bahwa dalam pelaksanaan kegiatan pengadaan sejak perencanaan harus menerapkan prinsip pengadaan barang dan jasa berdasarkan prinsip efisien, efektif, kompetitif, transparan dan bertangungjawab. Berkaitan dengan dimensi penerapan eprocurement, Willem (2012:11-12) mengemukakan bahwa untuk mendukung penerapan e-procurement ada beberapa dimensi yang 
harus dipenuhi yang meliputi : a. Efisien; b. Efektif; c. Kompetitif; d. Transparan; dan e. bertanggung jawab.

Dengan demikian dapat diduga terdapat pengaruh Penerapan Electronic Procurement terhadap Kinerja Pengadan Barang/Jasa pada Bagian Pengadaan Barang dan Jasa Sekretariat Daerah Kabupaten Pandeglang.

\section{B.2. Pengaruh Good Governance Terhadap Kinerja Pengadaan Barang/Jasa pada Bagian Pengadaan Barang dan Jasa Sekretariat Daerah Kabupaten Pandeglang.}

Kinerja berasal dari kata job performance atau actual performance yang berarti prestasi kerja atau prestasi sesungguhnya yang dicapai oleh seseorang. Pengertian kinerja (prestasi kerja) adalah hasil kerja secara kualitas dan kuantitas yang dicapai oleh seorang pegawai dalam melaksanakan fungsinya sesuai dengan tanggung jawab yang diberikan kepadanya.

Kinerja lembaga adalah suatu usaha yang dilakukan oleh lembaga dalam rangka untuk mencapai prestasi yang lebih baik, baik berupa hasil kerja maupun proses kerjanya. Adapun dimensi dari kinerja lembaga menurut Muhaimin (2010:374) terdiri dari : 1) Konteks; 2) Input; 3) Proses; 4) Output; dan 5) Outcame.

Kinerja pengadaan barang/jasa dapat dipengaruhi oleh faktor Good Governance. Secara umum, governance diartikan sebagai kualitas hubungan antara pemerintah dan masyarakat 
yang dilayani dan dilindunginya, private sectors (sektor swasta/ dunia usaha), dan society (masyarakat). Oleh sebab itu, Good Governance sektor publik diartikan sebagai suatu proses tata kelola pemerintahan yang baik, dengan melibatkan stakeholders terhadap berbagai kegiatan perekonomian, sosial politik, dan pemanfaatan berbagai sumber daya seperti sumber daya alam, keuangan, dan manusia bagi kepentingan rakyat yang dilaksanakan dengan menganut asas keadialan, pemerataan, persamaan, efisiensi, transparansi, dan akuntabilitas (Sedarmayanti, 2007: 2).

Jumlah komponen ataupun prinsip yang melandasi tata pemerintahan yang baik sangat bervariasi dari satu institusi ke institusi lain, dari satu pakar ke pakar lainnya. Namun paling tidak ada sejumlah prinsip yang dianggap sebagai prinsip- prinsip utama yang melandasi Good Governance, yaitu akuntabilitas, kejelasan dan ketersediaan, dan partisipasi (Sedarmayanti, 2009:289).

Dengan demikian dapat diduga terdapat pengaruh Good Governance terhadap Kinerja Pengadaan Barang/Jasa pada Bagian Pengadaan Barang dan Jasa Sekretariat Daerah Kabupaten Pandeglang. 
B.3. Pengaruh Penerapan Electonic Procurement dan Good Governance Secara Bersama-sama terhadap Kinerja Pengadaan Barang/Jasa pada Bagian Pengadaan Barang dan Jasa Sekretariat Daerah Kabupaten Pandeglang.

Kinerja berasal dari kata job performance atau actual performance yang berarti prestasi kerja atau prestasi sesungguhnya yang dicapai oleh seseorang. Pengertian kinerja (prestasi kerja) adalah hasil kerja secara kualitas dan kuantitas yang dicapai oleh seorang pegawai dalam melaksanakan fungsinya sesuai dengan tanggung jawab yang diberikan kepadanya.

Kinerja lembaga adalah suatu usaha yang dilakukan oleh lembaga dalam rangka untuk mencapai prestasi yang lebih baik, baik berupa hasil kerja maupun proses kerjanya. Adapun dimensi dari kinerja lembaga menurut Muhaimin (2010:374) terdiri dari : 1) Konteks; 2) Input; 3) Proses; 4) Output; dan 5) Outcame.

Kinerja pengadaan barang/jasa dipengaruhi oleh faktor Penerapan Electronic Procurement. Willem (2012:11) yang menyatakan bahwa dalam pelaksanaan kegiatan pengadaan sejak perencanaan harus menerapkan prinsip pengadaan barang dan jasa berdasarkan prinsip efisien, efektif, kompetitif, transparan dan bertangungjawab. Berkaitan dengan dimensi penerapan eprocurement, Willem (2012:11-12) mengemukakan bahwa untuk mendukung penerapan e-procurement ada beberapa dimensi yang 
harus dipenuhi yang meliputi : a. Efisien; b. Efektif; c. Kompetitif; d. Transparan; dan e. bertanggung jawab.

Kinerja pengadaan barang/jasa juga dapat dipengaruhi oleh faktor Good Governance. Secara umum, governance diartikan sebagai kualitas hubungan antara pemerintah dan masyarakat yang dilayani dan dilindunginya, private sectors (sektor swasta/ dunia usaha), dan society (masyarakat). Oleh sebab itu, Good Governance sektor publik diartikan sebagai suatu proses tata kelola pemerintahan yang baik, dengan melibatkan stakeholders terhadap berbagai kegiatan perekonomian, sosial politik, dan pemanfaatan berbagai sumber daya seperti sumber daya alam, keuangan, dan manusia bagi kepentingan rakyat yang dilaksanakan dengan menganut asas keadialan, pemerataan, persamaan, efisiensi, transparansi dan akuntabilitas (Sedarmayanti, 2007: 2).

Jumlah komponen ataupun prinsip yang melandasi tata pemerintahan yang baik sangat bervariasi dari satu institusi ke institusi lain, dari satu pakar ke pakar lainnya. Namun paling tidak ada sejumlah prinsip yang dianggap sebagai prinsip- prinsip utama yang melandasi Good Governance, yaitu akuntabilitas, kejelasan dan ketersediaan, dan partisipasi (Sedarmayanti, 2009:289).

Dengan demikian dapat diduga terdapat pengaruh penerapan Electronic Procurement dan Good Governance secara bersama-sama terhadap Kinerja Pengadaan Barang/Jasa pada 
Bagian Pengadaan Barang dan Jasa Sekretariat Daerah Kabupaten Pandeglang.

Untuk model penelitian ini adalah deskriptif yaitu untuk menggambarkan variabel dan eksplanasi serta pengumpulan data melalui metode survei. Penelitian ini bersifat asosiatif yaitu ada hubungan atau pengaruh antara dua variabel atau lebih. Ditegaskan Sugiyono (2004:36) bahwa yang dimaksud dengan hubungan causal adalah hubungan yang bersifat sebab akibat. Dalam penelitian ini bermaksud menjelaskan pengaruh variabel bebas terhadap variabel terikat. Berikut ini model kerangka konseptual penelitian :

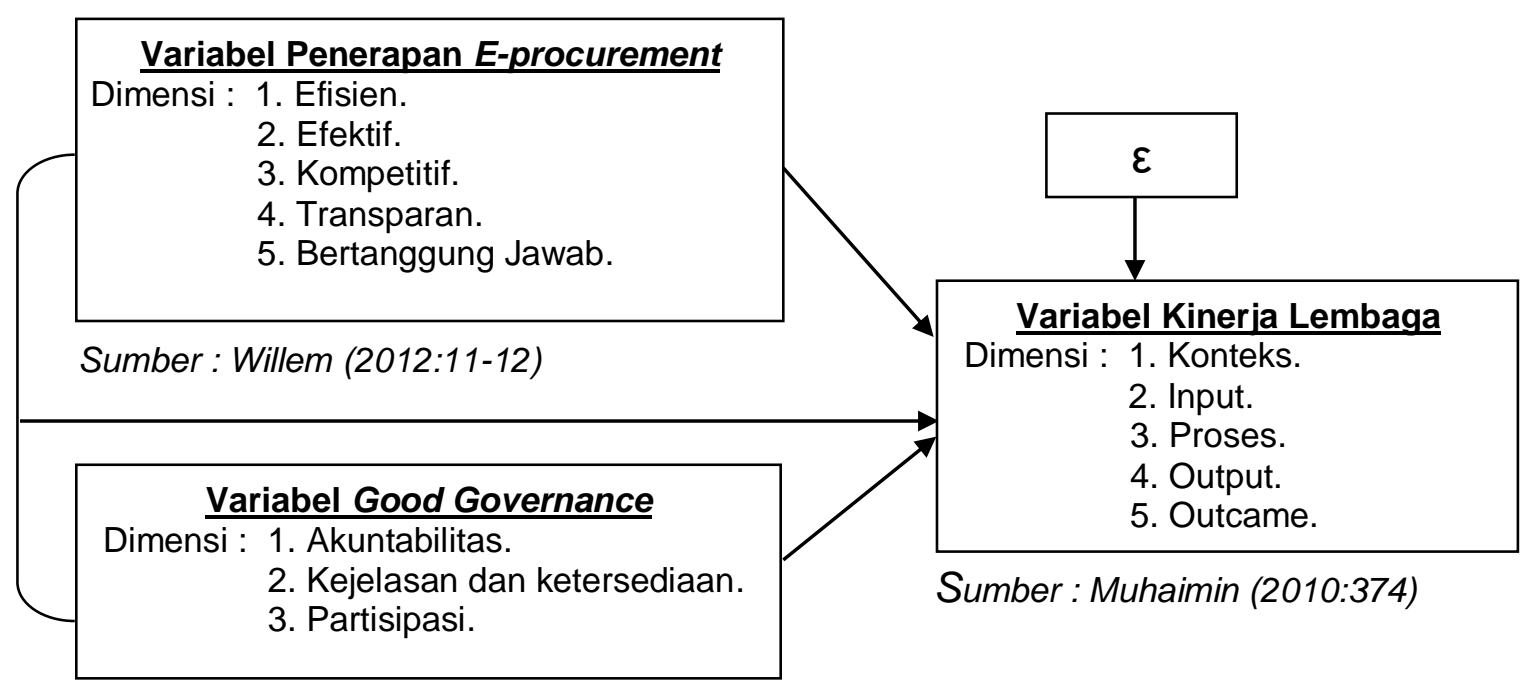

Sumber : Sedarmayanti (2009:289)

Gambar 2.1. Model Kerangka Konseptual Penelitian 


\section{Hipotesis}

Diketahui hipotesis dari penelitian mengenai pengaruh Penerapan Electronic Procurement dan Good Governance terhadap Kinerja Pengadaan Barang/Jasa pada Bagian Pengadaan Barang dan Jasa Sekretariat Daerah Kabupaten Pandeglang adalah :

1. Penerapan Electronic Procurement berpengaruh terhadap Kinerja Pengadaan Barang/Jasa pada Bagian Pengadaan Barang dan Jasa Sekretariat Daerah Kabupaten Pandeglang.

2. Good Governance berpengaruh terhadap Kinerja Pengadaan Barang/Jasa pada Bagian Pengadaan Barang dan Jasa Sekretariat Daerah Kabupaten Pandeglang.

3. Penerapan Electronic Procurement dan Good Governance secara bersama-sama berpengaruh terhadap Kinerja Pengadaan Barang/Jasa pada Bagian Pengadaan Barang dan Jasa Sekretariat Daerah Kabupaten Pandeglang. 


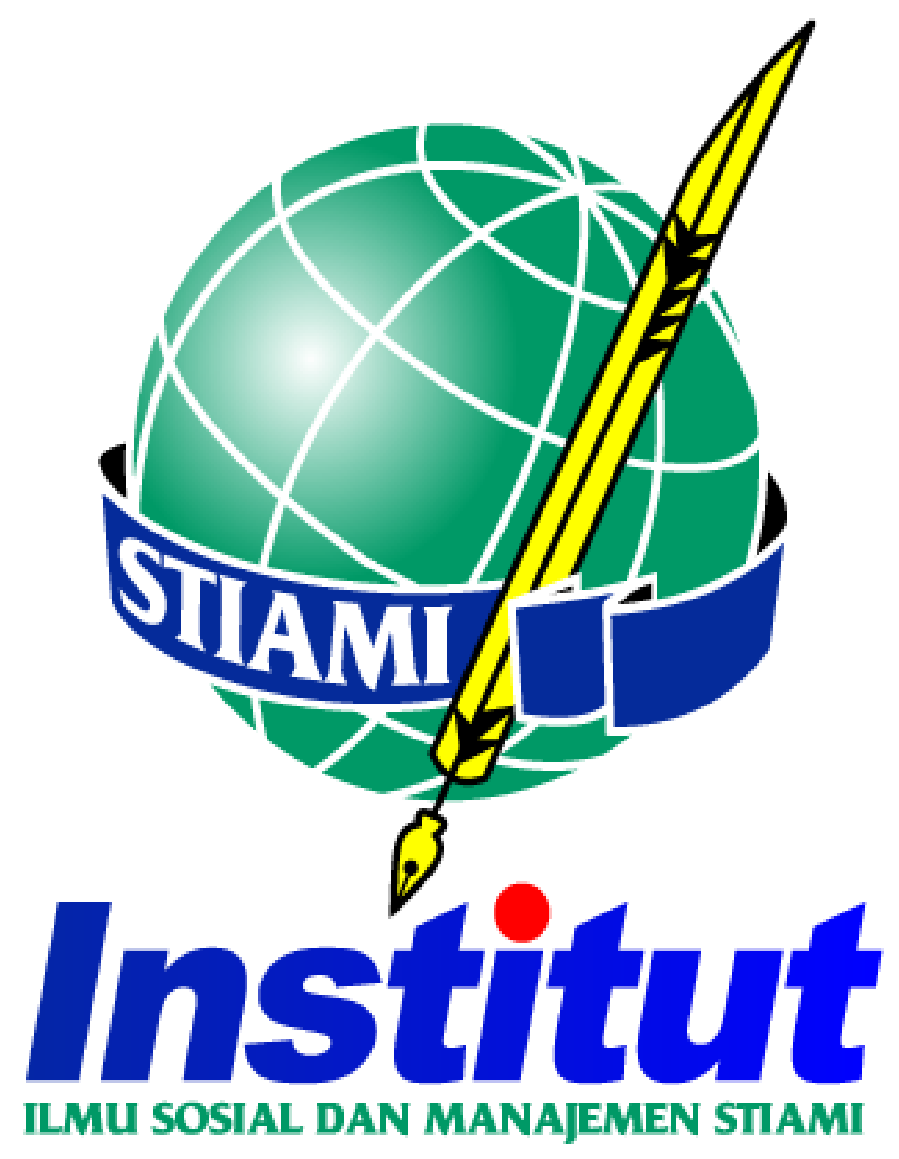




\section{BAB III \\ METODE PENELITIAN}

\section{A. Pendekatan Penelitian}

Metode pendekatan penelitian yang digunakan dalam penelitian ini yaitu pendekatan kuantitatif analisis regresi untuk melihat seberapa besar pengaruh variabel bebas dan variabel terikat. Pendekatan ini lebih mengandalkan angka-angka berupa skor sebagai kerangka dasar analisis. Skor tersebut diperoleh dengan metode survei. Metode ini menurut Kerlinger \& Lee (2000:599), lazimnya digunakan pada populasi besar maupun kecil, tetapi data yang dipelajari adalah data dari sampel yang diambil dari populasi tersebut, sehingga ditemukan kejadian-kejadian relatif, distribusi dan hubungan-hubungan antar variabel.

Adapun untuk survei pada penelitian ini dimaksudkan untuk mempelajari sikap, keyakinan, nilai-nilai, demografi, tingkah laku, opini, kebiasaan, keinginan, ide-ide, dan tipe informasi lain yang diperlukan untuk kepentingan penelitian (Mcmillan \& Schumacher, 2006:233). Dari data, fakta atau informasi yang diperoleh melalui survei tersebut dapat digambarkan kondisi masing-masing variabel yang diteliti sehingga memungkinkan untuk diketahui Pengaruh Penerapan Electronic Procurement dan Good Governance Terhadap Kinerja Pengadaan Barang/Jasa pada Bagian Pengadaan Barang dan Jasa Sekretariat Daerah Kabupaten Pandeglang. 
Berdasarkan pada tujuan dari penelitian ini yaitu berupa kajian terhadap Kinerja Pengadaan Barang/Jasa pada Bagian Pengadaan Barang dan Jasa Sekretariat Daerah Kabupaten Pandeglang, maka hasilnya diharapkan dapat menjadi pedoman atau bahan perbandingan dalam meningkatkan Kinerja Pengadaan Barang/Jasa. Hasil penelitian ini diharapkan dapat digunakan oleh pegawai di lingkungan Bagian Pengadaan Barang dan Jasa Sekretariat Daerah Kabupaten Pandeglang.

Kajian terhadap data penelitian akan disajikan secara redaksional serta akan menjelaskan pengaruh indikator-indikator Penerapan Electronic Procurement dan Good Governance terhadap indikator yang terkandung dalam konsep Kinerja Pengadaan Barang/Jasa. Oleh karena itu, berdasarkan dimensi tujuan penjelasan, penelitian ini menerapkan dimensi penjelasan.

Dimensi yang sesuai dengan penelitian ini adalah dimensi cross-sectional 'satu periode tertentu dalam satu waktu' yakni penelitian ini meliputi beberapa bulan dalam satu tahun yaitu antara bulan Mei 2018 sampai dengan Oktober 2018.

Pada penulisan penelitian ini, teknik pengumpulan data yang relevan dipilih penulis adalah dimensi survei karena terdapat populasi dari objek penelitian. Dari populasi tersebut kemudian ditarik sampel dengan rumus-rumus statistik yang sesuai dengan teknik pengambilan sampel yang digunakan. 
Model penelitian adalah sebagai berikut :

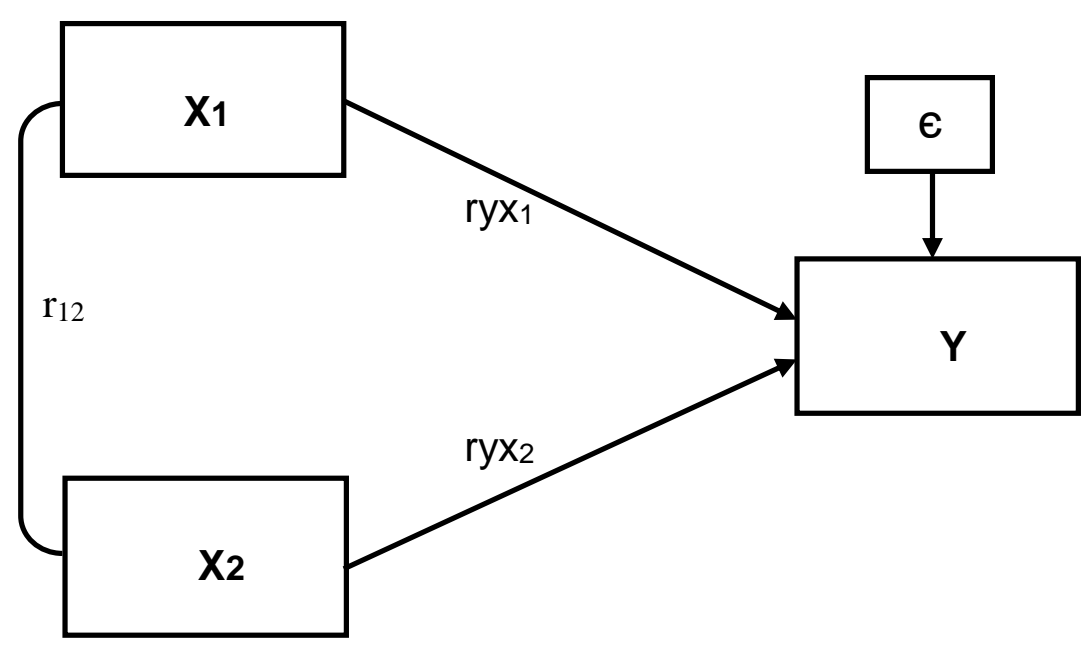

Gambar 3.1

Design Penelitian

Keterangan :

$\mathrm{X}_{1}$ : Penerapan Electronic Procurement

$\mathrm{X}_{2}$ : Good Governance

Y : Kinerja Lembaga

$\epsilon \quad$ : Faktor-faktor lain di luar $\mathrm{X}_{1}$, dan $\mathrm{X}_{2}$ yang mempengaruhi terhadap $Y$ akan tetapi tidak diteliti

$\mathrm{r}_{12} \quad$ : Koefisien korelasi $\mathrm{X}_{1}$ dan $\mathrm{X}_{2}$

$r_{X 1 Y}:$ Koefisien korelasi $X_{1}$ dan $Y$.

rX2Y : Koefisien korelasi $\mathrm{X}_{2}$ dan $\mathrm{Y}$.

B. Operasional Variabel

1. Definisi Konseptual

1. Penerapan Electronic Procurement.

Dalam pelaksanaan kegiatan pengadaan sejak perencanaan harus menerapkan prinsip pengadaan barang dan jasa berdasarkan prinsip efisien, efektif, kompetitif, transparan dan bertangungjawab. 


\section{Good Governance}

Jumlah komponen ataupun prinsip yang melandasi tata pemerintahan yang baik sangat bervariasi dari satu institusi ke institusi lain, dari satu pakar ke pakar lainnya. Namun paling tidak ada sejumlah prinsip yang dianggap sebagai prinsipprinsip utama yang melandasi good governance, yaitu akuntabilitas, kejelasan dan ketersediaan, dan partisipasi.

4. Kinerja Lembaga

Kinerja lembaga adalah suatu usaha yang dilakukan oleh lembaga dalam rangka untuk mencapai prestasi yang lebih baik, baik berupa hasil kerja maupun proses kerjanya. Adapun dimensi dari kinerja lembaga menurut Muhaimin (2010:374) terdiri dari : 1) Konteks; 2) Input; 3) Proses; 4) Output; dan 5) Outcame.

\section{Kisi-kisi Variabel Penelitian}

Dengan memperhatikan pada kisi-kisi variabel dalam penelitian ini yang memuat deskripsi dimensi (subvariabel), dimana setiap dimensi dirumuskan indikatornya untuk kemudian menjadi item angket (quisionery). Adapun kisi-kisi variabel dalam penelitian ini adalah : 
Tabel 3.1

Kisi-Kisi Variabel

\begin{tabular}{|c|c|c|c|c|}
\hline Variabel & Dimensi & Indikator & $\begin{array}{l}\text { No } \\
\text { Item }\end{array}$ & $\begin{array}{l}\text { Jml } \\
\text { Item }\end{array}$ \\
\hline \multirow{5}{*}{$\begin{array}{l}\text { Penerapan E- } \\
\text { Procurrement } \\
\quad\left(\mathbf{X}_{1}\right)\end{array}$} & - Efisien & $\begin{array}{l}\text { - penggunaan dana } \\
\text { - penggunaan daya } \\
\text { - penggunaan fasilitas }\end{array}$ & $\begin{array}{l}1 \\
2 \\
3\end{array}$ & 3 \\
\hline & - Efektif & $\begin{array}{l}\text { - sesuai dengan kebutuhan } \\
\text { - memberikan manfaat }\end{array}$ & $\begin{array}{l}4 \\
5\end{array}$ & 2 \\
\hline & - Kompetitif & $\begin{array}{l}\text { - proses seleksi dan persaingan } \\
\text { - memenuhi syarat/kriteria }\end{array}$ & $\begin{array}{l}6 \\
7\end{array}$ & 2 \\
\hline & - Transparan & $\begin{array}{l}\text { - informasi pengadaan barang/jasa } \\
\text { - administrasi pengadaan } \\
\text { - penetapan calon penyedia } \\
\text { barang/jasa }\end{array}$ & $\begin{array}{c}8 \\
9 \\
10\end{array}$ & 3 \\
\hline & - Bertanggung jawab & $\begin{array}{l}\text { - sasaran fisik keuangan } \\
\text { - pelaksanaan prinsip-prinsip dan } \\
\text { kebijakan }\end{array}$ & $\begin{array}{l}11 \\
12\end{array}$ & 2 \\
\hline \multirow[t]{3}{*}{$\begin{array}{c}\text { Good } \\
\text { Governance } \\
\quad\left(\mathbf{X}_{2}\right) \\
\text { Sedarmayanti } \\
(2009: 289)\end{array}$} & - Akuntabilitas & $\begin{array}{l}\text { - pembuatan keputusan dilakukan } \\
\text { secara tertulis } \\
\text { - pembuatan keputusan sudah } \\
\text { memenuhi standar } \\
\text { - kejelasan sasaran kebijakan } \\
\text { - konsistensi target operasional }\end{array}$ & $\begin{array}{l}1 \\
2 \\
3 \\
4\end{array}$ & 4 \\
\hline & $\begin{array}{l}\text { - Kejelasan dan } \\
\text { ketersediaan }\end{array}$ & $\begin{array}{l}\text { - kejelasan tugas dan kewenangan } \\
\text { - ketersediaan informasi publik } \\
\text { - proses pengangaran secara } \\
\text { terbuka } \\
\text { - jaminan integritas }\end{array}$ & $\begin{array}{l}5 \\
6 \\
7 \\
8\end{array}$ & 4 \\
\hline & - Partisipasi & $\begin{array}{l}\text { - keterlibatan masyarakat } \\
\text { - peran aktif masyarakat }\end{array}$ & $\begin{array}{c}9 \\
10\end{array}$ & 2 \\
\hline
\end{tabular}


Lanjutan Tabel 3.1

\begin{tabular}{|c|c|c|c|c|}
\hline $\begin{array}{l}\text { Kinerja } \\
\text { Lembaga } \\
\text { (Y) }\end{array}$ & - Konteks & $\begin{array}{l}\text { - landasan religius dan hukum } \\
\text { - kondisi geografis dan demografis } \\
\text { - tantangan masa depan }\end{array}$ & $\begin{array}{l}1 \\
2 \\
3\end{array}$ & 3 \\
\hline \multirow[t]{4}{*}{$\begin{array}{l}\text { Muhaimin } \\
(2010: 374)\end{array}$} & - Input & $\begin{array}{l}\text { - visi dan misi } \\
\text { - sumber daya }\end{array}$ & $\begin{array}{l}4 \\
5\end{array}$ & 2 \\
\hline & - Proses & $\begin{array}{l}\text { - pengambilan keputusan } \\
\text { - pengelolaan program } \\
\text { - evaluasi }\end{array}$ & $\begin{array}{l}6 \\
7 \\
8\end{array}$ & 3 \\
\hline & - Output & $\begin{array}{l}\text { - prestasi kerja } \\
\text { - kenaikan pangkat/golongan }\end{array}$ & $\begin{array}{c}9 \\
10\end{array}$ & 2 \\
\hline & - Outcame & $\begin{array}{l}\text { - jenjang karier } \\
\text { - peluang berkembang } \\
\text { - penghasilan }\end{array}$ & $\begin{array}{l}11 \\
12 \\
13\end{array}$ & 3 \\
\hline
\end{tabular}

\section{Teknik Pengumpulan Data}

Untuk teknik pengumpulan data dalam penelitian ini dapat diuraian sebagai berikut :

a. Studi Pustaka

Teknik pengumpulan data yang dimaksudkan untuk mendapatkan teori dan informasi yang erat hubungannya dengan materi penelitian yang dilakukan dengan mempelajari buku-buku referensi, laporan-laporan terdahulu, majalah-majalah, dan media lainnya.

b. Observasi

Teknik pengumpulan data yang dilakukan melalui pengamatan dan pencatatan secara sistematis serta langsung terhadap obyek yang diteliti. 
c. Angket

Teknik pengumpulan data yang dilakukan dengan menggunakan atau menyiapkan daftar pernyataan yang sudah disusun terlebih dahulu untuk dijawab oleh responden. Angket dalam penelitian ini bersifat tertutup, artinya responden hanya dapat menjawab pernyataan dengan memilih salah satu alternatif yang ada.

Dengan memperhatikan angket yang diajukan kepada responden, untuk variabel Penerapan Electronic Procurement sebanyak 12 pernyataan, variabel Good Governance sebanyak 10 pernyataan, dan variabel Kinerja sebanyak 13 pernyataan. Pernyataan-pernyataan tersebut disusun sedemikian rupa secara terperinci dan lengkap yang harus dijawab responden dengan memilih salah satu alternatif jawaban yang telah disediakan dengan ketentuan "angket yang digunakan dalam penelitian ini disusun menurut model skala likert dan dirumuskan dengan 5 kategori”.

Pernyataan yang dikemukakan bersifat kualitatif, untuk keperluan analisis data tersebut disesuaikan dengan sifat pernyataan angket. Pernyataan yang bersifat positif diberi skor 5,4,3,2,1 dan untuk pernyataan yang bersifat negatif diberi skor 1,2,3,4,5.

Penentuan skor adalah :
a. Jawaban Sangat Setuju
(SS)
b. Jawaban Setuju
c. Jawaban Kurang Setuju
d. Jawaban Tidak Setuju
e. Jawaban Sangat Tidak Setuju
dengan skor 5 dengan skor 4 dengan skor 3 dengan skor 2 dengan skor 1 


\section{Teknik Sampling}

\section{Populasi}

Menurut Sugiyono (2004:57) menyatakan bahwa populasi adalah : "wilayah generalisasi yang terdiri atas subjek/objek yang mempunyai kuantitas dan karakteristik tertentu yang ditetapkan oleh peneliti untuk dipelajari dan kemudian ditarik kesimpulannya". Adapun populasi dalam penelitian ini adalah pegawai pada Bagian Pengadaan Barang dan Jasa Sekretariat Daerah Kabupaten Pandeglang dengan jumlah populasi sebanyak 41 pegawai dengan rincian sebagai berikut :

Tabel 3.2

Populasi Responden

\begin{tabular}{|c|l|c|}
\hline No & Bagian/Bidang & Jumlah Pegawai \\
\hline 1 & Sekretariat & 11 \\
2 & Pokja & 20 \\
3 & Penyedia Barang/Jasa & 10 \\
\hline \multicolumn{2}{|c|}{ Jumlah } & 41 \\
\hline
\end{tabular}

\section{Sampel}

Pengertian sampel menurut Irwan Soehartono (1999:58) yaitu "terdapat dua syarat yang harus dipenuhi dalam prosedur pengambilan sampel, yaitu : sampel harus mewakili (representatif) dan besarnya sampel harus bisa "memadai". Untuk memenuhi kedua syarat tersebut digunakan pendekatan statistik dalam mengambil besarnya sampel yang baik, dengan menentukan error atau kesalahan yang dapat ditoleransi dalam pengambilan sampel. 
Adapun untuk menentukan sampel yang dilakukan dalam penelitian ini adalah dengan menggunakan teknik total sampling, sehingga jumlah sampel dalam penelitian ini sebanyak 41 orang responden.

\section{E. Teknik Analisis Data}

\section{E.1. Uji Instrumen}

\section{a. Uji Validitas}

Suatu instrumen dari variabel penelitian sebelum digunakan untuk mengumpulkan data, terlebih dahulu diuji untuk mengukur validitasnya. Uji validitas berarti prosedur pengujian untuk melihat apakah alat ukur yang berupa kuesioner dapat mengukur dengan cermat atau tidak. Uji validitas dipergunakan untuk mengukur kecermatan setiap nomor item angket.

Teknik pengujian validitas dengan membandingkan hasil perhitungan skor butir, dimana dikatakan valid apabila $r$ hitung lebih besar dari $r$ tabel dengan taraf signifikansi minimal 95\%. Adapun untuk rumus $\mathrm{r}$ hitung yang digunakan adalah:

$$
r_{\text {hitung }}=\frac{n\left(\sum X Y\right)-\left(\sum X\right) \cdot\left(\sum Y\right)}{\sqrt{\left\{n \cdot \sum X^{2}-\left(\sum X\right)^{2}\right\} \cdot\left\{n \cdot \sum Y^{2}-\left(\sum Y\right)^{2}\right\}}}
$$

Dimana :

$r$ hitung : Koefisien Korelasi

$\Sigma X \quad:$ Jumlah skor butir

$\Sigma Y \quad$ : Jumlah total skor butir 


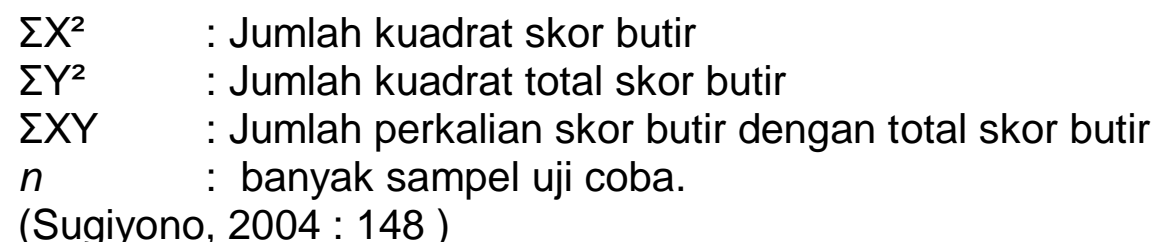

\section{b. Uji Reliabilitas}

Uji keandalan atau reliabilitas digunakan untuk mengukur suatu angket, yang disusun berdasarkan indikator variabel. Suatu instrumen dikatakan reliabel atau handal jika jawaban terhadap instrumen penelitian adalah konsisten atau stabil dari waktu ke waktu. Pengujian reliabilitas terhadap variabel dilakukan dengan metode Alpha Cronbach. Alpha Cronbach, dengan rumus :

$$
r_{11}=\frac{k}{k-1}\left(1-\frac{\sum \sigma_{b}^{2}}{\sigma_{t}^{2}}\right)
$$

Dimana :

$\begin{array}{ll}\mathrm{r}_{11} & : \text { Koefisien korelasi instrumen } \\ \mathrm{k} & : \text { Banyaknya butir yang valid } \\ \sum \sigma_{b}^{2} & : \text { Jumlah varian butir } \\ \sigma_{t}^{2} & : \text { Total varian }\end{array}$

Dimana apabila nilai Alpha Cronbach di atas 0,7 (Alpha Cronbach $>0,7)$ maka instrumen dinyatakan reliebel. (Sugiyono, 2004: 147). 


\section{E.2. Menentukan perhitungan statistik dasar}

Pengukuran gejala pemusatan atau gejala penyebaran data yang tidak dikelompokkan (data tunggal) dari hasil penelitian, menggunakan rumus:

Rentang ( $R$ )

$$
=\text { data terbesar }- \text { data terkecil }
$$

Rata-rata

$$
=\frac{\sum X_{1}}{n}
$$

Simapangan baku $(\mathrm{s})=\sqrt{\frac{n \sum X_{t}^{2}-\left(X_{1}\right)^{2}}{n(n-1)}}$

(Riduwan, 2003: 102,157)

Pengukuran gejala pemusatan dan gejala penyebaran data hasil penelitian dalam distribusi frekuensi, menggunakan rumus :

Rata-rata $\left(\bar{X}_{1}\right)=\frac{\sum f_{1} X_{1}}{n}$

Modus $(\mathrm{Mo})=b_{0}+P\left(\frac{d 1}{d 1+d 2}\right)$

Dimana :

$b_{1}=$ Batas bawah nyata kelas modus

$d_{1}=$ Selisih frekuensi kelas modus oleh frekuensi sebelumnya

$\mathrm{d}_{2}=$ Selisish frekuensi kelas modus oleh frekuensi kelas sesudahnya

$\mathrm{p}=$ panjang interval kelas

$\operatorname{Median}(\mathrm{Me})=b_{0}+p\left(\frac{\frac{n}{2}-F}{f}\right)$

Dimana :

$\mathrm{B}_{0}=$ batas bawah nyata kelas modus

$\mathrm{F} \quad=$ Frekuensi komulatif sebelum kelas median

I = panjang kelas interval

$\mathrm{N}$ = Banyaknya data. (Riduwan, 2003:115-120). 


\section{E.3. Uji Persyaratan Analisis}

\section{a. Uji Normalitas}

Untuk keperluan pengujian normalitas data dilakukan dengan uji Kolmogorov-Smirnov Analysis dengan taraf signifikan 0,05. Apabila nilai signifikansi Alpha Kolmogorov-Smirnov diatas 0,05, maka dapat disimpulkan bahwa variabel berasal dari data yang berdistribusi normal.

\section{b. Uji Multikolinearitas}

Multikolinearitas adalah suatu hubungan linear yang sempurna (mendekati sempurna) antara beberapa atau semua variabel bebas. Multikolinearitas juga berarti kondisi dimana terjadi korelasi atau hubungan yang kuat diantara variabel bebas. Dalam analisis regresi berganda, harus terbebas dari gejala multikolinearitas.

Ada tidaknya gejala multikolinearitas bisa dicermati dari indikasi nilai VIP (Variance Inflation Factor) $<10$. Bila nilai VIF $<10$ berarti baik atau tidak ada gejala multikolinearitas

\section{c. Uji Autokorelasi}

Uji Autokorelasi bertujuan untuk menguji apakah dalam model regresi linear ada korelasi antara kesalahan pengganggu pada periode $\mathrm{t}$ dengan kesalahan pengganggu pada periode $\mathrm{t}-1$ (sebelumnya). Autokorelasi muncul karena observasi yang berurutan sepanjang waktu berkaitan satu sama lain. 
Untuk mendeteksi ada tidaknya autokorelasi dilakukan dengan menggunakan uji Durbin-Watson (DW-Test). Model regresi dikatakan tidak terdapat autokorelasi apabila nilai Durbin-Watson berkisar 1,55 sampai 2,46.

\section{d. Uji Heterokedastisitas}

Uji heterokedastisitas bertujuan untuk menguji apakah dalam model regresi terjadi ketidaksamaan varians dari residual satu pengamatan ke pengamatan yang lain. Model regresi yang baik adalah yang tidak terjadi heterokedastisitas. Pengujian heterokedastisitas dilakukan dengan menggunakan grafik scatterplot. Dasar analisis yang digunakan untuk mengambil keputusan adalah sebagai berikut :

1. Jika ada pola tertentu, seperti titik-titik yang ada membentuk pola tertentu yang teratur (bergelombang, melebar kemudian menyempit), maka mengindikasikan telah terjadi heterokedastisitas.

2. Jika tidak ada pola yang jelas, serta titik-titik menyebar di atas dan di bawah angkan 0 pada sumbu $\mathrm{Y}$, maka tidak terjadi heterokedastisitas. 


\section{E.4. Uji Hipotesis}

\section{a. Uji Signifikansi Parsial (Uji Statistik t)}

Dalam penelitian ini diajukan tiga hipotesis untuk mengetahui dan menganalisis pengaruh dua variabel bebas terhadap variabel terikat, yaitu:

- Hipotesis Pertama

Untuk menguji apakah terdapat pengaruh Penerapan EProcurement $\left(\mathrm{X}_{1}\right)$ terhadap Kinerja Pegawai $(\mathrm{Y})$

$\mathrm{H}_{0}: \mathrm{b}_{1}=0$ : Penerapan E-Procurement tidak berpengaruh positif dan signifikan terhadap Kinerja Pegawai.

$\mathrm{H}_{1}: \mathrm{b}_{1} \# 0$ : Penerapan E-Procurement berpengaruh positif dan signifikan terhadap Kinerja Pegawai

Jika thitung $>$ tabel, maka $\mathrm{H}_{0}$ ditolak dan konsekuensinya $\mathrm{H}_{1}$ diterima, demikian sebaliknya.

- Hipotesis Kedua

Untuk menguji apakah terdapat pengaruh Good Governance $\left(\mathrm{X}_{2}\right)$ terhadap Kinerja Pegawai $(\mathrm{Y})$

$\mathrm{H}_{0}: \mathrm{b}_{2}=0$ : Good Governance tidak berpengaruh positif dan signifikan terhadap Kinerja Pegawai.

$\mathrm{H}_{1}: \mathrm{b}_{2} \# 0$ : Good Governance berpengaruh positif dan signifikan terhadap Kinerja Pegawai 
Jika thitung $>$ tabel, maka $\mathrm{H}_{0}$ ditolak dan konsekuensinya $\mathrm{H}_{1}$ diterima, demikian sebaliknya.

- Hipotesis Ketiga

Dilakukan untuk menguji apakah terdapat pengaruh Penerapan E-Procurement $\left(\mathrm{X}_{1}\right)$ dan Good Governance $\left(\mathrm{X}_{2}\right)$ secara bersama-sama terhadap Kinerja Pegawai $(\mathrm{Y})$

$$
\begin{aligned}
\mathrm{H}_{0}: \mathrm{b}_{3}=0 \text { : } & \text { Penerapan E-Procurement dan Good } \\
& \text { Governance secara bersama-sama tidak } \\
& \text { berpengaruh positif dan signifikan terhadap } \\
& \text { Kinerja Pegawai. } \\
\mathrm{H}_{1}: \mathrm{b}_{3} \# 0: & \text { Penerapan E-Procurement dan Good } \\
& \text { Governance secara bersama-sama } \\
& \text { berpengaruh positif dan signifikan terhadap } \\
& \text { Kinerja Pegawai. }
\end{aligned}
$$

Apabila Fhitung $>$ Ftabel, maka $\mathrm{H}_{0}$ ditolak dan konsekuensinya $\mathrm{H}_{1}$ diterima,demikian sebaliknya.

Adapun uji statistik t berguna untuk menguji pengaruh dari masingmasing variabel independen secara parsial terhadap variabel dependen. Untuk mengetahui ada tidaknya pengaruh masingmasing variabel independen secara parsial terhadap variabel dependen dapat dilihat pada tabel berikut di bawah ini. Hasil uji statistik $\mathrm{t}$ dapat dilihat dengan kriteria jika nilai probability thitung $>$ 
ttabel maka $\mathrm{H}_{1}$ diterima, sedangkan jika nilai probability thitung $<$ tabel maka $\mathrm{H}_{0}$ diterima.

\section{b. Uji Signifikan Simultan (Uji Statistik F)}

Uji statistik $\mathrm{F}$ bertujuan untuk mengetahui pengaruh secara bersama-sama atau simultan variabel independen terhadap variabel dependen atau terikat. Kriteria yang digunakan adalah apabila nilai $F_{\text {hitung }}>F_{\text {tabel }}$ maka $\mathrm{H}_{0}$ ditolak dan konsekuensinya $\mathrm{H}_{1}$ diterima, demikian sebaliknya.

\section{E.5. Analisis Jalur}

Berikutnya menganalisis pengaruh variabel-variabel bebas terhadap variabel terikat. Adapun analisis uji pengaruh melalui analisis jalur yang hasil perhitungannya dilakukan dengan menggunakan aplikasi SPSS for Windows ver. 22.00.

a) Besarnya pengaruh Penerapan E-Procurement $\left(X_{1}\right)$ terhadap Kinerja Pegawai $(Y)$ adalah sebagai berikut :

- Pengaruh langsung sebesar :

$\operatorname{ryx}_{1} \times \operatorname{ryx}_{1}$

- Pengaruh tidak langsung $\left(\mathrm{X}_{2}\right)$ sebesar :

$\operatorname{ryx}_{1} \times \operatorname{rx}_{1} x_{2} \times$ ryx $_{2}$

- Pengaruh total sebesar :

Pengaruh langsung + Pengaruh tidak langsung $\left(\mathrm{X}_{2}\right)$ 
b) Besarnya pengaruh Good Governance $\left(\mathrm{X}_{2}\right)$ terhadap Kinerja Pegawai $(\mathrm{Y})$ adalah :

- Pengaruh langsung sebesar :

$\operatorname{ryx}_{2} \times$ ryx $_{2}$

- Pengaruh tidak langsung $\left(X_{1}\right)$ sebesar :

$\operatorname{ryx} 2 x \operatorname{rx}_{2} \mathrm{X}_{1} \times \mathrm{ryx}_{1}$

- Pengaruh total sebesar :

Pengaruh langsung + Pengaruh tidak langsung $\left(X_{1}\right)$

c) Besarnya pengaruh Penerapan E-Procurement $\left(X_{1}\right)$ dan Good Governance $\left(\mathrm{X}_{2}\right)$ secara bersama-sama terhadap Kinerja Pegawai (Y) adalah :

Pengaruh total penerapan E-procurement $\left(\mathrm{X}_{1}\right)+$ Pengaruh total Good Governance $\left(\mathrm{X}_{2}\right)$

\section{F. Lokasi dan Jadwal Penelitian}

Lokasi penelitian berada pada Bagian Pengadaan Barang dan Jasa Sekretariat Daerah Kabupaten Pandeglang sejak Mei 2018 sampai dengan Oktober 2018. Adapun jadwal penelitian dapat dilihat pada tabel berikut : 
Tabel 3.3

Jadwal Penelitian

\begin{tabular}{|c|l|c|c|c|c|c|c|}
\hline \multirow{2}{*}{ No } & \multicolumn{1}{|c|}{ Tahapan Kegiatan } & \multicolumn{5}{|c|}{ Tahun 2018} \\
\cline { 3 - 8 } & & Mei & Jun & Jul & Agu & Sep & Okt \\
\hline 1 & Penyusunan Proposal & $X$ & & & & & \\
\hline 2 & Pengajuan Proposal & $X$ & & & & & \\
\hline 3 & Seminar Proposal & & $X$ & & & & \\
\hline 4 & Penelitian Laporan & & $X$ & $X$ & & & \\
\hline 5 & Penulisan Tesis & & & & $X$ & $X$ & \\
\hline 6 & Telaah Sidang & & & & & & $X$ \\
\hline 7 & Sidang & & & & & & $X$ \\
\hline
\end{tabular}




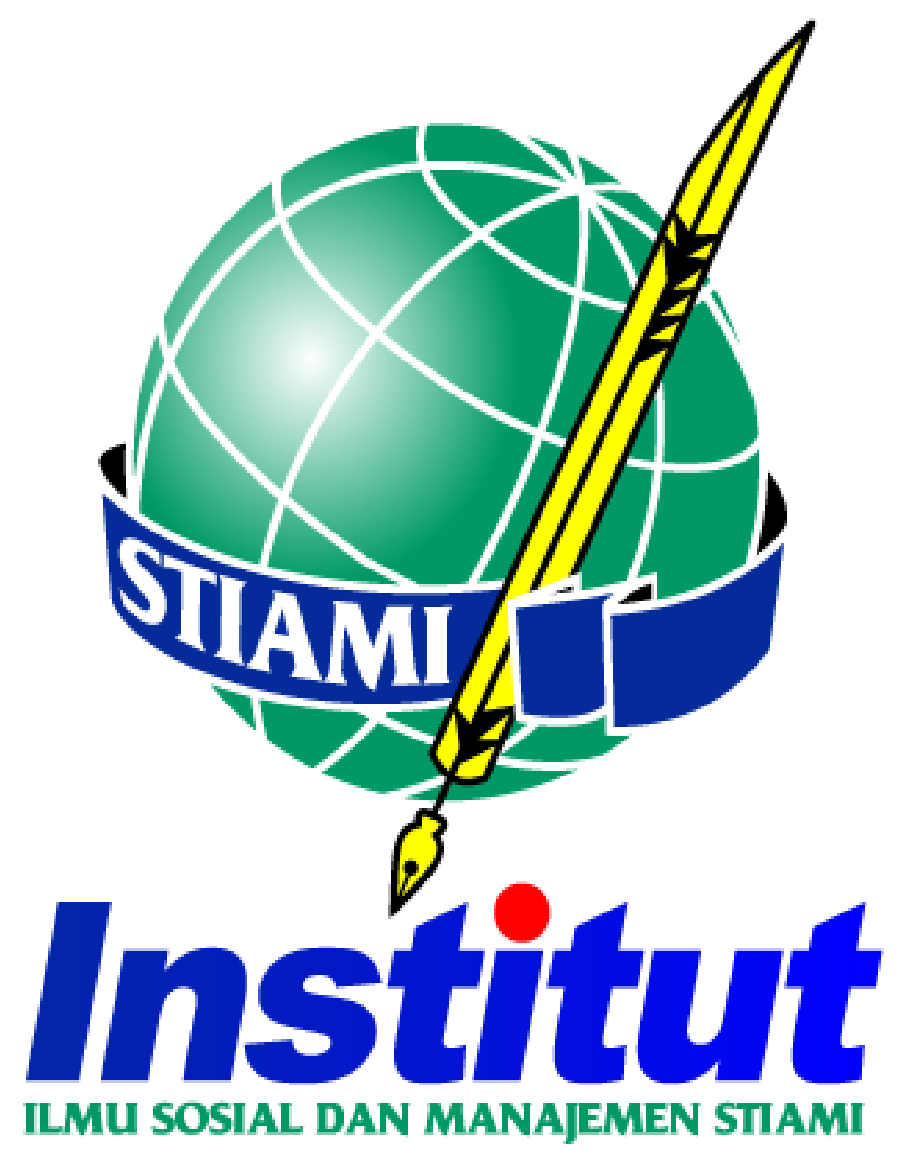




\section{BAB IV}

\section{HASIL PENELITIAN DAN PEMBAHASAN}

\section{A. HASIL PENELITIAN}

\section{A.1. Gambaran Umum Objek Penelitian}

Berdasarkan Pada Peraturan Bupati Pandeglang Nomor 37 Tahun 2016 Tentang Kedudukan, Susunan Organisasi, Rincian Tugas Dan Fungsi, Serta Tata Kerja Kerja Sekretariat Daerah Dan Staf Ahli Bupati. Sekretariat Daerah merupakan unsur staf dipimpin oleh Sekretaris Daerah yang berkedudukan di bawah dan bertanggung jawab kepada Bupati. Adapun Susunan Organisasi Sekretariat Daerah terdiri dari :

a. Unsur Pimpinan adalah Sekretaris Daerah;

Sekretaris Daerah mempunyai tugas membantu Bupati dalam penyusunan kebijakan dan pengoordinasian administratif terhadap pelaksanaan tugas Perangkat Daerah serta pelayanan administratif.

b. Unsur Pembantu Pimpinan adalah Asisten Sekretaris Daerah terdiri dari:

1. Asisten Pemerintahan.

Asisten Pemerintahan mempunyai tugas merumuskan kebijakan, mengkoordinasikan, mengendalikan, memantau, mengevaluasi, melaporkan pelaksanaan urusan pemerintahan di bidang Pengawasan, Kesatuan Bangsa dan Politik, 
Pemberdayaan Masyarakat dan Pemerintah Desa, Kependudukan dan Pencatatan Sipil, Satuan Polisi Pamong Praja, Pelayanan Kecamatan, Desa dan Kelurahan, Pemerintahan Umum, Kerjasama Daerah, Hukum, Organisasi serta Pelayanan Publik dan Kinerja Perangkat Daerah. Asisten Pemerintahan membawahkan:

a) Bagian Tata Pemerintahan.

Kepala Bagian Tata Pemerintahan mempunyai tugas pokok merumuskan dan melaksanakan kebijakan bidang umum pemerintahan, bidang Pembinaan Otonomi Daerah, dan bidang Pembinaan Wilayah. Bagian Tata Pemerintahan terdiri dari:

1) Subbagian Umum Pemerintahan;

2) Subbagian Bina Otonomi Daerah;

3) Subbagian Bina Wilayah.

b) Bagian Hukum.

Kepala Bagian Hukum mempunyai tugas pokok merumuskan dan melaksanakan kebijakan bidang perundang-undangan, bantuan hukum, dokumentasi dan informasi hukum. Bagian Hukum terdiri dari:

1) Subbagian Perundang-undangan;

2) Subbagian Bantuan Hukum;

3) Subbagian Dokumentasi dan Informasi Hukum. 
c) Bagian Kerjasama Daerah.

Kepala Bagian Kerja Sama Daerah mempunyai tugas pokok melaksanakan sebagian tugas Asisten Pemerintahan lingkup Kerja Sama Daerah. Bagian Kerjasama Daerah terdiri dari:

1) Subbagian Kerjasama Pemerintah;

2) Subbagian Kerjasama Non Pemerintah; dan

3) Subbagian Hubungan Antar Lembaga.

d) Bagian Organisasi.

Kepala Bagian Organisasi mempunyai tugas pokok memimpin, merencanakan, mengatur dan mengendalikan seluruh kegiatan Bagian Organisasi dalam rangka penyelenggaraan sebagian tugas Asisten Pemerintahan di bidang organisasi. Bagian Organisasi terdiri dari :

1) Subbagian Kelembagaan dan Analisa Jabatan;

2) Subbagian Tata laksana dan Pelayanan Publik; dan

3) Subbagian Akuntabilitas Kinerja Perangkat Daerah.

2. Asisten Ekonomi Pembangunan dan Kesejahteraan Rakyat.

Asisten Pembangunan Ekonomi dan Kesejahteraan Rakyat mempunyai tugas merumuskan kebijakan, mengkoordinasikan, mengendalikan, memantau, mengevaluasi, melaporkan pelaksanaan urusan pemerintahan di bidang Perencanaan, Pekerjaan Umum, Penataan Ruang, 
Perumahan dan kawasaan Permukiman, Perhubungan, Koperasi dan UMKM, Perindustrian, Perdagangan, Pertanian, Peternakan, Kelautan, Perikanan, Kehutanan, Perkebunan, Ketahanan Pangan, Pariwisata, Pendidikan Kebudayaan, Kesehatan dan Pemuda dan Olahraga, serta Lingkungan Hidup. Asisten Ekonomi Pembangunan dan Kesejahteraan Rakyat membawahkan:

a) Bagian Administrasi Kesejahteraan Rakyat.

Kepala Bagian Administrasi Kesejahteraan Rakyat mempunyai tugas pokok merumuskan dan melaksanakan kebijakan bidang kesejahteraan sosial, keagamaan, Pendidikan dan Kesehatan. Bagian Administrasi Kesejahteraan Rakyat terdiri dari:

1) Subbagian Pendidikan dan Kesehatan;

2) Subbagian Kesejahteraan Sosial; dan

3) Subbagian Kemasyarakatan dan Keagamaan.

b) Bagian Administrasi Pembangunan.

Kepala Bagian Administrasi Pembangunan mempunyai tugas pokok memimpin, merencanakan, mengatur dan mengendalikan seluruh kegiatan Bagian Administrasi Pembangunan dalam rangka penyelenggaraan sebagian tugas Asisten Ekonomi Pembangunan, dan Kesejahteraan Rakyat di bidang administrasi, pengendalian, evaluasi dan 
pelaporan pelaksanaan Kegiatan Fisik dan Kegiatan Non Fisik. Bagian Administrasi Pembangunan terdiri dari:

1) Subbagian Pengendalian Pembangunan;

2) Subbagian Evaluasi Pembangunan; dan

3) Subbagian Bina Administrasi Pembangunan.

c) Bagian Administrasi Perekonomian.

Kepala Bagian Administrasi Perekonomian mempunyai tugas pokok merencanakan operasional, mengelola, mengoordinasikan, mengendalikan, mengevaluasi dan melaporkan program dan kegiatan di bidang perekonomian dengan ruang lingkup pengembangan potensi dan produksi, fasilitasi pemberdayaan ekonomi daerah dan pengembangan Usaha Daerah. Bagian Administrasi Perekonomian terdiri dari:

1) Subbagian Ekonomi;

2) Subbagian Pengembangan Potensi dan Produksi; dan

3) Subbagian Usaha Daerah.

d) Bagian Pengadaan Barang Jasa.

Kepala Bagian Pengadaan Barang dan Jasa mempunyai tugas pokok memimpin, merencanakan, mengatur, mengendalikan, melaksanakan dan menyelenggarakan seluruh kegiatan Pengadaan Barang dan Jasa Pemerintah. Bagian Pengadaan Barang dan Jasa terdiri dari: 
1) Subbagian Pelayanan Pengadaan Barang Jasa;

2) Subbagian Data Dan Informasi Pengadaan; dan

3) Subbagian Administrasi Pengadaan Barang Dan Jasa.

3. Asisten Administrasi Umum.

Asisten Administrasi Umum mempunyai tugas merumuskan, mengoordinasikan, mengendalikan, memantau, mengevaluasi, melaporkan pelaksanaan urusan pemerintah di bidang Pengelolaan Keuangan dan Aset, Pendapatan, Perpustakaan, Arsip dan Dokumentasi, Komunikasi, Informasi dan Statistik serta melaksanakan dan membina ketatausahaan, perlengkapan, keprotokolan, dan rumah tangga, mengelola keuangan Sekretariat Daerah dan Kepala Daerah serta melaksanakan penyusunan pedoman dan petunjuk teknis pelaksanaan urusan kehumasan. Asisten Administrasi Umum membawahkan:

a) Bagian Humas dan Protokol.

Kepala Bagian Hubungan Masyarakat dan Protokol mempunyai tugas pokok memimpin, merencanakan, mengatur dan mengendalikan seluruh kegiatan Bagian Hubungan Masyarakat dan Protokol. Bagian Humas dan Protokol terdiri dari :

1) Subbagian Protokol;

2) Subbagian Pemberitaan; dan 
3) Subbagian Dokumentasi dan Peliputan.

b) Bagian Perlengkapan dan Rumah Tangga.

Kepala Bagian Perlengkapan dan Rumah Tangga mempunyai tugas pokok memimpin, merencanakan, mengatur dan mengendalikan seluruh kegiatan Bagian Perlengkapan dan Rumah Tangga dalam rangka penyelenggaraan sebagian tugas Asisten Administrasi Umum di bidang perlengkapan dan Rumah Tangga pimpinan dan Sekretariat Daerah. Bagian Perlengkapan dan Rumah Tangga terdiri dari:

1) Subbagian Perlengkapan;

2) Subbagian Rumah Tangga; dan

3) Subbagian Pencatatan dan Pemeliharaan.

c) Bagian Keuangan, Perencanaan dan Pelaporan. Kepala Bagian Keuangan, Perencanaan dan Pelaporan mempunyai tugas pokok memimpin, merencanakan, mengatur, dan mengendalikan seluruh kegiatan Bagian Keuangan, Perencanaan, Evaluasi dan Pelaporan dalam rangka penyelenggaraan sebagian tugas Asisten Administrasi Umum di bidang pengelolaan keuangan, perencanaan dan pelaporan Sekretariat Daerah. Bagian Keuangan, Perencanaan dan Pelaporan terdiri dari: 
1) Subbagian Anggaran;

2) Subbagian Perbendaharaan dan Verifikasi; dan

3) Subbagian Perencanaan, Evaluasi dan Pelaporan.

d) Bagian Umum.

Kepala Bagian Umum mempunyai tugas pokok memimpin, merencanakan, mengatur dan mengendalikan seluruh kegiatan Bagian Umum dalam rangka penyelenggaraan sebagian tugas Asisten Administrasi Umum di bidang umum. Bagian Umum terdiri dari:

1) Subbagian Tata Usaha Pimpinan;

2) Subbagian Tata Usaha Staf Ahli; dan

3) Subbagian Kepegawaian.

4. Kelompok Jabatan Fungsional.

5. Staf Ahli Bupati.

\section{A.2. Deskripsi Responden Penelitian}

Berdasarkan pengumpulan data pada penelitian ini diperoleh data primer maupun sekunder, selanjutnya data tersebut diolah berdasarkan data-data yang telah terkumpul melalui alat pengumpul data. Adapun sesuai dengan jumlah responden yang telah ditetapkan sebelumnya, sebanyak 35 pernyataan angket disebarkan kepada responden dan dikembalikan secara keseluruhan. 
Berikutnya setelah data angket dipilah-pilah, ternyata secara keseluruhan memenuhi syarat dan layak untuk dilakukan analisis lebih lanjut. Kemudian data diolah dengan menggunakan alat bantu Program SPSS 22 for Windows.

\section{A.3. Hasil Uji Validitas Data}

Untuk uji validitas terhadap item/butir pernyataan angket dilakukan dengan menggunakan teknik Corrected Item Total Correlation. Untuk mengujikan bahwa korelasi tersebut signifikan atau tidak, maka hasil uji rhitung dapat dibandingkan dengan $r_{\text {tabel }}$ dengan taraf signifikansi $95 \%$. Suatu item dikatakan valid bila rhitung $>$ rtabel. Menurut Sugiono (2007:134), jika rhitung $>0,308$, maka item instrumen dinyatakan valid. Adapun untuk perhitungan uji validitas dilakukan dengan bantuan program komputer SPSS versi 22 dengan hasil sebagai berikut :

\section{- Penerapan E-Procurement $\left(\mathbf{X}_{1}\right)$}

Untuk hasil uji validitas terhadap variabel Penerapan EProcurement $\left(\mathrm{X}_{1}\right)$ diperoleh dengan membandingkan nilai $\mathrm{r}_{\text {hitung }}$ dengan rabel yang dapat dilihat perbandingannya pada tabel berikut : 
Tabel 4.1.

Hasil Uji Validitas Variabel Penerapan E-Procurement $\left(\mathrm{X}_{1}\right)$

\begin{tabular}{|c|l|c|c|c|}
\hline No & Item Pernyataan & $\mathbf{r}$ hitung & $\mathbf{r}$ tabel & Ket \\
\hline 1 & Pernyataan_1 & 0,461 & 0,308 & Valid \\
\hline 2 & Pernyataan_2 & 0,394 & 0,308 & Valid \\
\hline 3 & Pernyataan_3 & 0,469 & 0,308 & Valid \\
\hline 4 & Pernyataan_4 & 0,415 & 0,308 & Valid \\
\hline 5 & Pernyataan_5 & 0,464 & 0,308 & Valid \\
\hline 6 & Pernyataan_6 & 0,323 & 0,308 & Valid \\
\hline 7 & Pernyataan_7 & 0,310 & 0,308 & Valid \\
\hline 8 & Pernyataan_8 & 0,465 & 0,308 & Valid \\
\hline 9 & Pernyataan_9 & 0,397 & 0,308 & Valid \\
\hline 10 & Pernyataan_10 & 0,440 & 0,308 & Valid \\
\hline 11 & Pernyataan_11 & 0,514 & 0,308 & Valid \\
\hline 12 & Pernyataan_12 & 0,323 & 0,308 & Valid \\
\hline
\end{tabular}

Sumber : olahan data SPSS 2018

Berdasarkan hasil olahan data SPSS pada tabel diatas diketahui dari 12 item pernyataan data uji coba instrumen Penerapan E-Procurement $\left(\mathrm{X}_{1}\right)$ semua instrumen penelitian adalah valid atau semua $r_{\text {hitung }}>r_{\text {tabel. }}$ Sehingga dari 12 item pernyataan yang ada dalam angket Penerapan E-Procurement $\left(X_{1}\right)$ semua item pernyataan dapat dipergunakan untuk penelitian.

\section{- Good Governance $\left(\mathrm{X}_{2}\right)$}

Untuk hasil uji validitas terhadap variabel Good Governance $\left(\mathrm{X}_{2}\right)$ diperoleh dengan membandingkan nilai rhitung dan $\mathrm{r}_{\text {tabel }}$ yang dapat dilihat perbandingannya pada tabel berikut : 
Tabel 4.2.

Hasil Uji Validitas Variabel Good Governance $\left(\mathrm{X}_{2}\right)$

\begin{tabular}{|c|l|c|c|c|}
\hline No & Item Pernyataan & $\mathbf{r}$ hitung & $\mathbf{r}$ tabel & Ket \\
\hline 1 & Pernyataan_1 & 0,442 & 0,308 & Valid \\
\hline 2 & Pernyataan_2 & 0,513 & 0,308 & Valid \\
\hline 3 & Pernyataan_3 & 0,562 & 0,308 & Valid \\
\hline 4 & Pernyataan_4 & 0,371 & 0,308 & Valid \\
\hline 5 & Pernyataan_5 & 0,575 & 0,308 & Valid \\
\hline 6 & Pernyataan_6 & 0,380 & 0,308 & Valid \\
\hline 7 & Pernyataan_7 & 0,431 & 0,308 & Valid \\
\hline 8 & Pernyataan_8 & 0,530 & 0,308 & Valid \\
\hline 9 & Pernyataan_9 & 0,324 & 0,308 & Valid \\
\hline 10 & Pernyataan_10 & 0,368 & 0,308 & Valid \\
\hline
\end{tabular}

Sumber : olahan data SPSS 2018

Berdasarkan hasil olahan data SPSS pada tabel diatas diketahui dari 10 item pernyataan data uji coba instrumen Good Governance $\left(\mathrm{X}_{2}\right)$ semua instrumen penelitian adalah valid atau semua rhitung $>\mathrm{r}_{\text {tabel. }}$ Sehingga dari 10 item pernyataan yang ada dalam angket Good Governance $\left(\mathrm{X}_{2}\right)$ semua item pernyataan dapat dipergunakan untuk penelitian.

\section{- Kinerja Lembaga}

Untuk hasil uji validitas terhadap variabel Kinerja Lembaga (Y) diperoleh dengan membandingkan nilai rhitung dan $r_{\text {tabel }}$ yang dapat dilihat perbandingannya pada tabel berikut : 
Tabel 4.3

Hasil Uji Validitas Variabel Kinerja Lembaga (Y)

\begin{tabular}{|c|l|c|c|c|}
\hline No & Item Pernyataan & $\mathbf{r}$ hitung & $\mathbf{r}$ tabel & Ket \\
\hline 1 & Pernyataan_1 & 0,458 & 0,308 & Valid \\
\hline 2 & Pernyataan_2 & 0,517 & 0,308 & Valid \\
\hline 3 & Pernyataan_3 & 0,318 & 0,308 & Valid \\
\hline 4 & Pernyataan_4 & 0,584 & 0,308 & Valid \\
\hline 5 & Pernyataan_5 & 0,733 & 0,308 & Valid \\
\hline 6 & Pernyataan_6 & 0,407 & 0,308 & Valid \\
\hline 7 & Pernyataan_7 & 0,346 & 0,308 & Valid \\
\hline 8 & Pernyataan_8 & 0,690 & 0,308 & Valid \\
\hline 9 & Pernyataan_9 & 0,605 & 0,308 & Valid \\
\hline 10 & Pernyataan_10 & 0,537 & 0,308 & Valid \\
\hline 11 & Pernyataan_11 & 0,632 & 0,308 & Valid \\
\hline 12 & Pernyataan_12 & 0,502 & 0,308 & Valid \\
\hline 13 & Pernyataan_13 & 0,549 & 0,308 & Valid \\
\hline
\end{tabular}

Sumber : olahan data SPSS 2018

Berdasarkan hasil olahan data SPSS pada tabel diatas diketahui dari 13 item pernyataan data uji coba instrumen Kinerja Lembaga (Y) semua instrumen penelitian adalah valid atau semua rhitung > rtabel. Sehingga dari 13 item pernyataan yang ada dalam angket Kinerja Lembaga (Y) semua item pernyataan dapat dipergunakan untuk penelitian.

\section{A.4. Reliabilitas Instrumen}

Dalam menentukan uji keandalan (reliabilitas) instrumen pada penelitian ini dianalisa dengan menggunakan teknik Alpha Cronbach's. Indek reliabilitas dinyatakan dalam reliabel jika nilai Alpha Cronbach's yang diperoleh paling tidak sebesar 0,700. 
(perhitungan lengkap nilai Alpha Cronbach's terdapat pada lampiran 1).

- Berdasarkan pada hasil perhitungan koefisien reliabilitas instrumen Penerapan E-Procurement $\left(\mathrm{X}_{1}\right)$ diperoleh nilai Alpha Cronbach's $(\alpha)=0,775$.

- Berdasarkan pada hasil perhitungan koefisien reliabilitas instrumen Good Governance $\left(\mathrm{X}_{2}\right)$ diperoleh nilai Alpha Cronbach's $(\alpha)=0,782$.

- Berdasarkan pada hasil perhitungan koefisien reliabilitas instrumen Kinerja Lembaga $(Y)$ diperoleh nilai Alpha Cronbach's $(\alpha)=0,846$.

Dengan memperhatikan pada hasil perhitungan diatas diketahui bahwa semua instrumen dalam setiap variabel memiliki nilai Alpha Cronbach's ( $\alpha$ ) diatas 0,700. Sehingga dapat disimpulkan bahwa semua instrumen andal (reliabel) untuk digunakan dalam penelitian.

\section{A.5. Analisis Deskriptif Hasil Penelitian}

Untuk hasil analisis deskriptif pada masing-masing variabel dapat diuraikan sebagai berikut :

\section{a. Variabel Penerapan E-Procurement $\left(\mathrm{X}_{1}\right)$}

Berdasarkan hasil perhitungan analisis deskriptif untuk data variabel Penerapan E-Procurement $\left(\mathrm{X}_{1}\right)$ yang didapat dari hasil 
penelitian berlokasi di Bagian Pengadaan Barang dan Jasa Sekretariat Daerah Kabupaten Pandeglang, diperoleh skor ratarata (M) sebesar 49,41; Simpangan Baku (SD) sebesar 4,853; Median (Me) sebesar 50,00; Mode (Mo) sebesar 50; Nilai Minimum sebesar 42 dan Nilai Maksimum sebesar 60.

Tabel 4.4

Deskriptif Statistik Penerapan E-Procurement

\begin{tabular}{|l|r|}
\hline N $\quad$ Valid & 41 \\
Mean & 0 \\
Median & 49.41 \\
Mode & 50.00 \\
Std. Deviation & 50 \\
Minimum & 4.853 \\
Maximum & 42 \\
\hline
\end{tabular}

Kemudian untuk gambaran frekuensi hasil data penelitian variabel Penerapan E-Procurement $\left(\mathrm{X}_{1}\right)$, dapat disajikan dalam bentuk distribusi frekuensi pada tabel berikut :

Tabel 4.5

Distribusi Frekuensi Penerapan E-Procurement

\begin{tabular}{|c|c|c|c|}
\hline No & Skor & Frekuensi & Prosentase (\%) \\
\hline 1 & $42-44$ & 8 & 19,51 \\
\hline 2 & $45-47$ & 6 & 14,63 \\
\hline 3 & $48-50$ & 13 & 31,71 \\
\hline 4 & $51-53$ & 6 & 14,63 \\
\hline 5 & $54-56$ & 5 & 12,20 \\
\hline 6 & $57-59$ & 2 & 4,88 \\
\hline 7 & $60-62$ & 1 & 2,44 \\
\hline \multicolumn{2}{|c|}{ JUMLAH } & $\mathbf{4 1}$ & $\mathbf{1 0 0 , 0 0}$ \\
\hline
\end{tabular}


Berdasarkan tabel frekuensi di atas perolehan skor terbanyak berkisar pada kelompok skor 48-50 yaitu sebanyak $13(31,71 \%)$, sedangkan perolehan skor terkecil berada pada kisaran $60-62$ yaitu sebanyak 1 (2,44\%). Untuk memperjelas distribusi data variabel Penerapan E-Procurement $\left(X_{1}\right)$ tersebut, dapat dilihat pada Grafik Histogram berikut ini :

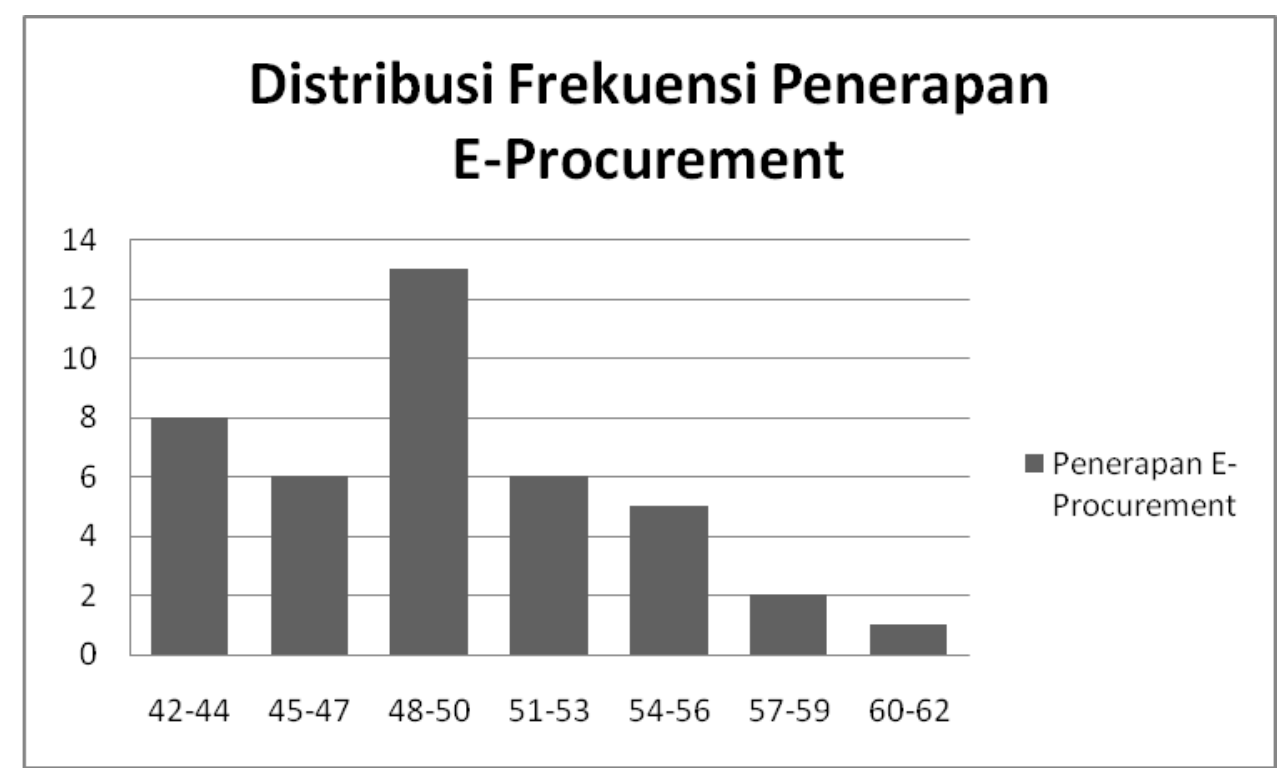

Gambar 4.1

Histogram Distribusi Frekuensi Variabel Penerapan E-Procurement $\left(\mathrm{X}_{1}\right)$

\section{b. Good Governance $\left(\mathrm{X}_{2}\right)$}

Berdasarkan hasil perhitungan analisis deskriptif untuk data variabel Good Governance $\left(\mathrm{X}_{2}\right)$ didapat dari hasil penelitian berlokasi di Bagian Pengadaan Barang dan Jasa Sekretariat Daerah Kabupaten Pandeglang, diperoleh skor rata-rata $(\mathrm{M})$ sebesar 41,24; Simpangan Baku (SD) sebesar 4,482; Median 
(Me) sebesar 41,00; Mode (Mo) sebesar 40; Nilai Minimum sebesar 34 dan Nilai Maksimum sebesar 50.

Tabel 4.6

Deskriptif Statistik Good Governance

\begin{tabular}{|l|r|}
\hline N $\quad$ Valid & 41 \\
& Missing \\
Mean & 41.24 \\
Median & 41.00 \\
Mode & 40 \\
Std. Deviation & 4.482 \\
Minimum & 34 \\
Maximum & 50 \\
\hline
\end{tabular}

Kemudian untuk gambaran frekuensi hasil data penelitian variabel Good Governance $\left(\mathrm{X}_{2}\right)$, dapat disajikan dalam bentuk distribusi frekuensi pada tabel berikut:

Tabel 4.7

Distribusi Frekuensi Good Governance

\begin{tabular}{|c|c|c|c|}
\hline No & Skor & Frekuensi & Prosentase (\%) \\
\hline 1 & $34-36$ & 9 & 21,95 \\
\hline 2 & $37-39$ & 4 & 9,76 \\
\hline 3 & $40-42$ & 11 & 26,83 \\
\hline 4 & $43-45$ & 9 & 21,95 \\
\hline 5 & $46-48$ & 6 & 14,63 \\
\hline 6 & $49-51$ & 2 & 4,88 \\
\hline \multicolumn{2}{|c|}{ JUMLAH } & $\mathbf{4 1}$ & $\mathbf{1 0 0 , 0 0}$ \\
\hline
\end{tabular}

Berdasarkan tabel frekuensi di atas perolehan skor terbanyak berkisar pada kelompok skor 40-42 yaitu sebanyak 11 (26,83\%), sedangkan perolehan skor terkecil berada pada kisaran 49-51 yaitu sebanyak 2 (4,88\%). Untuk memperjelas distribusi data 
variabel Good Governance $\left(\mathrm{X}_{2}\right)$ tersebut, dapat dilihat pada Grafik Histogram berikut ini :

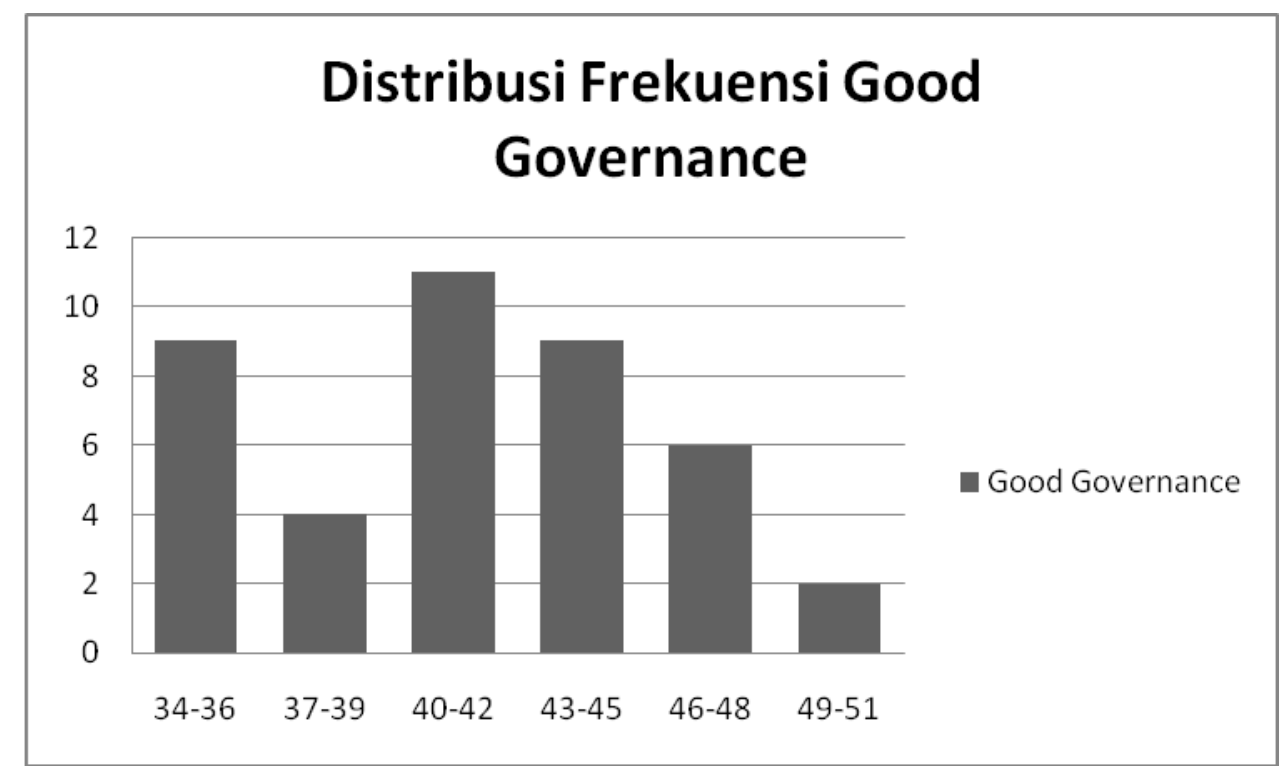

Gambar 4.2

Histogram Distribusi Frekuensi Variabel Good Governance $\left(\mathrm{X}_{2}\right)$

\section{c. Kinerja Lembaga $(\mathrm{Y})$}

Berdasarkan hasil perhitungan analisis deskriptif untuk data variabel Kinerja Lembaga $(\mathrm{Y})$ yang didapat dari hasil penelitian berlokasi di Bagian Pengadaan Barang dan Jasa Sekretariat Daerah Kabupaten Pandeglang, diperoleh skor rata-rata $(\mathrm{M})$ sebesar 53,56; Simpangan Baku (SD) sebesar 5,895; Median (Me) sebesar 54,00; Mode (Mo) sebesar 48; Nilai Minimum sebesar 43 dan Nilai Maksimum sebesar 64 . 
Tabel 4.8

Deskriptif Statistik Kinerja Lembaga

\begin{tabular}{|l|r|}
\hline N $\quad$\begin{tabular}{r} 
Valid \\
\multicolumn{1}{|c|}{ Missing }
\end{tabular} \\
Mean & \\
Median & 53.56 \\
Mode & 54.00 \\
Std. Deviation & 48 \\
Minimum & 5.895 \\
Maximum & 43 \\
\hline
\end{tabular}

Kemudian untuk gambaran frekuensi hasil data penelitian variabel Kinerja Lembaga $(Y)$, dapat disajikan dalam bentuk distribusi frekuensi pada tabel berikut:

Tabel 4.9

Distribusi Frekuensi Kinerja Lembaga

\begin{tabular}{|c|c|c|c|}
\hline No & Skor & Frekuensi & Prosentase (\%) \\
\hline 1 & $43-46$ & 6 & 14,63 \\
\hline 2 & $47-50$ & 9 & 21,95 \\
\hline 3 & $51-54$ & 6 & 14,63 \\
\hline 4 & $55-58$ & 10 & 24,39 \\
\hline 5 & $59-62$ & 8 & 19,51 \\
\hline 6 & $63-66$ & 2 & 4,88 \\
\hline \multicolumn{2}{|c|}{ JUMLAH } & $\mathbf{4 1}$ & $\mathbf{1 0 0 , 0 0}$ \\
\hline
\end{tabular}

Berdasarkan tabel frekuensi di atas perolehan skor terbanyak berkisar pada kelompok skor 55-58 yaitu sebanyak 10 (24,39\%), sedangkan perolehan skor terkecil berada pada kisaran 63-66 yaitu sebanyak 2 (4,88\%). Untuk memperjelas distribusi data variabel Kinerja Lembaga (Y) tersebut, dapat dilihat pada Grafik Histogram berikut ini : 


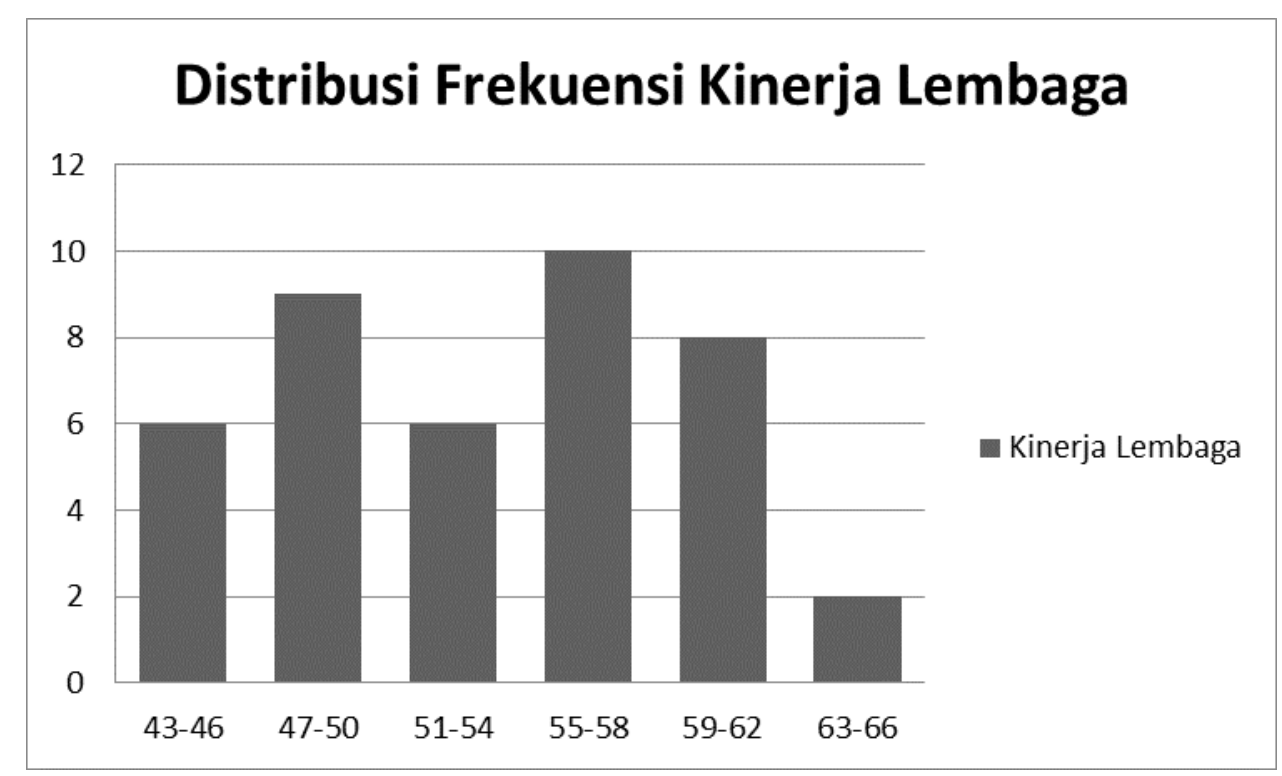

Gambar 4.3

Histogram Distribusi Frekuensi Variabel Kinerja Lembaga ( $Y$ )

\section{A.6. Method of Successive Interval (MSI)}

Dalam melakukan analisis regresi, data yang digunakan merupakan data kuantitatif yang memiliki skala pengukuran interval. Pada data yang dikompulir sekarang, baik data dependen maupun independen memiliki skala pengukuran ordinal, untuk itu skala pengukuran likert pada data perlu ditransformasi menjadi data dengan skala interval menggunakan method of successive interval untuk digunakan sebagai analisis lanjutan. Berikut adalah hasil transformasi dari setiap variabel : 
Tabel 4.10

Hasil Transformasi MSI

\begin{tabular}{|c|c|c|}
\hline $\mathbf{X 1}$ & $\mathbf{X 2}$ & $\mathbf{Y}$ \\
\hline 31,34 & 19,36 & 24,74 \\
\hline 22,59 & 22,86 & 23,30 \\
\hline 34,58 & 25,29 & 23,37 \\
\hline 23,99 & 17,06 & 21,25 \\
\hline 19,06 & 14,34 & 17,65 \\
\hline 20,06 & 15,39 & 20,98 \\
\hline 19,51 & 16,07 & 22,60 \\
\hline 29,06 & 25,12 & 38,55 \\
\hline 35,82 & 21,54 & 34,21 \\
\hline 28,48 & 21,22 & 23,47 \\
\hline 34,58 & 29,50 & 33,12 \\
\hline 19,02 & 17,54 & 18,57 \\
\hline 25,24 & 27,59 & 31,60 \\
\hline 40,83 & 32,19 & 37,64 \\
\hline 32,57 & 28,31 & 36,64 \\
\hline 25,90 & 21,17 & 26,47 \\
\hline 28,41 & 21,59 & 35,01 \\
\hline 29,20 & 22,64 & 30,64 \\
\hline 18,98 & 17,16 & 21,04 \\
\hline 21,40 & 17,27 & 23,67 \\
\hline 28,56 & 26,90 & 36,76 \\
\hline 21,85 & 21,49 & 35,36 \\
\hline 28,74 & 27,20 & 34,13 \\
\hline 38,18 & 30,67 & 42,32 \\
\hline 31,02 & 27,20 & 36,47 \\
\hline 28,74 & 28,80 & 29,12 \\
\hline 36,05 & 25,46 & 38,98 \\
\hline 28,64 & 23,52 & 35,19 \\
\hline 22,82 & 21,61 & 25,93 \\
\hline 29,74 & 22,20 & 26,99 \\
\hline 38,33 & 33,37 & 38,80 \\
\hline 23,44 & 15,47 & 23,25 \\
\hline 26,33 & 25,92 & 29,36 \\
\hline 22,40 & 17,61 & 25,57 \\
\hline 28,84 & 23,96 & 35,29 \\
\hline & & \\
\hline 25
\end{tabular}




\section{Lanjutan Tabel 4.10}

\begin{tabular}{|l|l|l|}
\hline 32,33 & 25,23 & 34,04 \\
\hline 26,10 & 15,77 & 27,93 \\
\hline 27,39 & 19,22 & 32,80 \\
\hline 21,50 & 17,11 & 18,81 \\
\hline 30,23 & 30,67 & 41,30 \\
\hline 35,91 & 29,94 & 37,72 \\
\hline
\end{tabular}

\section{A.7. Uji Asumsi Klasik}

\section{a. Uji Normalitas}

Dalam menentukan uji normalitas data dilakukan dengan uji Kolmogorov-Smirnov Analysis dengan taraf signifikan 0,05 dan jumlah $n=41$. Untuk perhitungannya dapat dilihat pada tabel berikut ini.

Tabel 4.11

Uji Normalitas Variabel

\begin{tabular}{|l|r|r|r|r|r|r|}
\hline & \multicolumn{4}{|c|}{ Kolmogorov-Smirnova $^{*}$} & \multicolumn{3}{c|}{ Shapiro-Wilk } \\
\cline { 2 - 7 } & Statistic & \multicolumn{1}{c|}{ df } & \multicolumn{1}{c|}{ Sig. } & \multicolumn{1}{c|}{ Statistic } & \multicolumn{1}{c|}{ df } & \multicolumn{1}{c|}{ Sig. } \\
\hline Penerapan E_Procurement & .111 & 41 & $.200^{*}$ & .959 & 41 & .144 \\
Good Governance & .099 & 41 & $.200^{*}$ & .955 & 41 & .106 \\
Kinerja Lembaga & .135 & 41 & .059 & .948 & 41 & .060 \\
\hline
\end{tabular}

- Dari hasil uji normalitas pada tabel di atas, terlihat bahwa

Signifikansi Alpha Kolmogorov-Smirnov dari variabel Penerapan E-Procurement $\left(X_{1}\right)$ sebesar 0,200 . Karena Signifikansi Alpha Kolmogorov-Smirnov diatas 0,05 (0,200 $>0,05)$ maka dapat disimpulkan bahwa variabel Penerapan 
E-Procurement $\left(\mathrm{X}_{1}\right)$ berasal dari data yang berdistribusi normal.

- Dari hasil uji normalitas pada tabel di atas, terlihat bahwa Signifikansi Alpha Kolmogorov-Smirnov dari variabel Good Governance $\left(\mathrm{X}_{2}\right)$ sebesar 0,200. Karena Signifikansi Alpha Kolmogorov-Smirnov diatas $0,05(0,200>0,05)$ maka dapat disimpulkan bahwa variabel Good Governance $\left(\mathrm{X}_{2}\right)$ berasal dari data yang berdistribusi normal.

- Dari hasil uji normalitas pada tabel di atas, terlihat bahwa Signifikansi Alpha Kolmogorov-Smirnov dari variabel Kinerja Lembaga $(Y)$ sebesar 0,059. Karena Signifikansi Alpha Kolmogorov-Smirnov diatas $0,05(0,059>0,05)$ maka dapat disimpulkan bahwa variabel Kinerja Lembaga (Y) berasal dari data yang berdistribusi normal.

\section{b. Uji Multikolinearitas}

Multikolinearitas adalah suatu hubungan linear yang sempurna (mendekati sempurna) antara beberapa atau semua variabel bebas. Multikolinearitas juga berarti kondisi dimana terjadi korelasi atau hubungan yang kuat diantara variabel bebas. Dalam analisis regresi berganda, harus terbebas dari gejala multikolinearitas. 
Ada tidaknya gejala multikolinearitas bisa dicermati dari indikasi nilai VIP (Variance Inflation Factor) $<10$. Bila nilai VIF $<10$ berarti baik atau tidak ada gejala multikolinearitas. Berikut ini hasil perhitungan uji multikolinearitas :

Tabel 4.12

Uji Multikolinearitas

\begin{tabular}{|c|c|c|c|c|c|c|c|}
\hline \multirow[b]{2}{*}{ Model } & \multicolumn{2}{|c|}{$\begin{array}{l}\text { Unstandardized } \\
\text { Coefficients }\end{array}$} & \multirow{2}{*}{$\begin{array}{c}\text { Standardized } \\
\text { Coefficients } \\
\text { Beta } \\
\end{array}$} & \multirow[b]{2}{*}{$t$} & \multirow[b]{2}{*}{ Sig. } & \multicolumn{2}{|c|}{$\begin{array}{l}\text { Collinearity } \\
\text { Statistics }\end{array}$} \\
\hline & B & Std. Error & & & & Tolerance & VIF \\
\hline (Constant) & 5.122 & 5.725 & & .895 & .377 & & \\
\hline Penerapan E_Procurement & .348 & .180 & .286 & 2.930 & .001 & .395 & 2.533 \\
\hline Good Governance & .758 & .195 & .576 & 3.889 & .000 & .395 & 2.533 \\
\hline
\end{tabular}

Dari hasil uji multikolinearitas pada tabel diatas, dapat dilihat bahwa nilai $\mathrm{VIF}<10$. Maka dapat disimpulkan bahwa tidak terjadi multikolinearitas antar variabel bebas.

\section{c. Uji Autokorelasi}

Uji Autokorelasi bertujuan untuk menguji apakah dalam model regresi linear ada korelasi antara kesalahan pengganggu pada periode $\mathrm{t}$ dengan kesalahan pengganggu pada periode $\mathrm{t}-1$ (sebelumnya). Autokorelasi muncul karena observasi yang berurutan sepanjang waktu berkaitan satu sama lain.

Untuk mendeteksi ada tidaknya autokorelasi dilakukan dengan menggunakan uji Durbin-Watson (DW-Test). Model regresi dikatakan tidak terdapat autokorelasi apabila nilai Durbin- 
Watson berkisar 1,55 sampai 2,46. Adapun hasil perhitungan uji autokorelasi dapat dilihat pada tabel berikut :

Tabel 4.13

Uji Autokorelasi

\begin{tabular}{|l|r|r|r|r|r|}
\hline Model & \multicolumn{1}{|c|}{$\mathrm{R}$} & $\mathrm{R}$ Square & \multicolumn{1}{c|}{$\begin{array}{c}\text { Adjusted } \mathrm{R} \\
\text { Square }\end{array}$} & $\begin{array}{c}\text { Std. Error of the } \\
\text { Estimate }\end{array}$ & Durbin-Watson \\
\hline 1 & $.819 \mathrm{a}$ & .671 & .653 & 3.471 & 1.852 \\
\hline
\end{tabular}

Dari hasil uji autokorelasi pada tabel diatas dapat dilihat bahwa nilai Durbin-Watson sebesar 1,852. Karena nilai Durbin-Watson berkisar antara 1,55 sampai 2,46, maka dapat disimpulkan bahwa tidak terjadi masalah autokorelasi.

\section{d. Uji Heterokedastisitas}

Uji heterokedastisitas bertujuan untuk menguji apakah dalam model regresi terjadi ketidaksamaan varians dari residual satu pengamatan ke pengamatan yang lain. Model regresi yang baik adalah yang tidak terjadi heterokedastisitas. Pengujian heterokedastisitas dilakukan dengan menggunakan grafik scatterplot. Dasar analisis yang digunakan untuk mengambil keputusan adalah sebagai berikut :

1. Jika ada pola tertentu, seperti titik-titik yang ada membentuk pola tertentu yang teratur (bergelombang, melebar kemudian menyempit), maka mengindikasikan telah terjadi heterokedastisitas. 
2. Jika tidak ada pola yang jelas, serta titik-titik menyebar di atas dan di bawah angkan 0 pada sumbu $\mathrm{Y}$, maka tidak terjadi heterokedastisitas.

Berikut ini hasil uji heterokedastisitas dengan menggunakan grafik scatterplot :

Scatterplot

Dependent Variable: Kinerja Pegawai

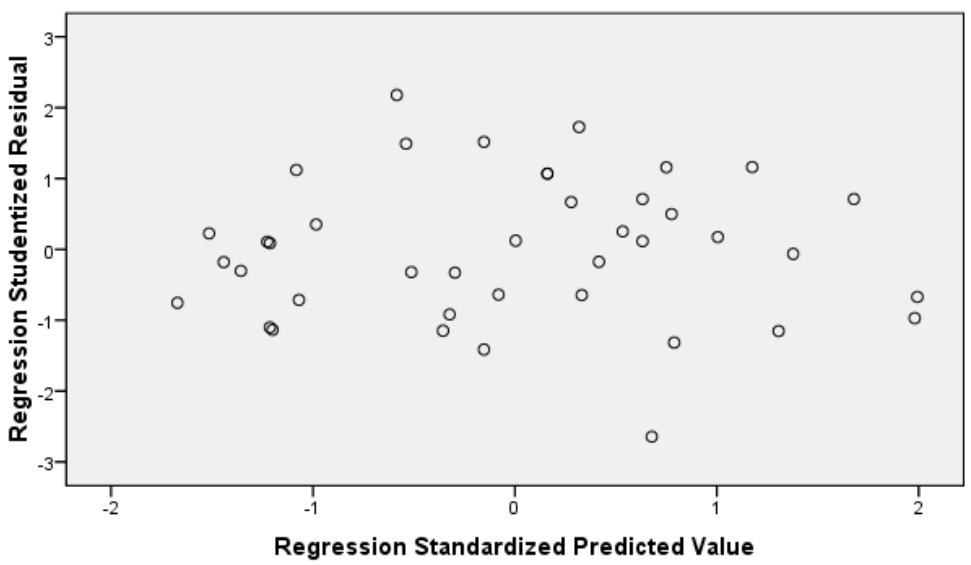

\section{Gambar 4.4 Grafik Scatterplot Uji Heterokedastisitas}

Dari hasil uji heterokedastisitas dengan menggunakan grafik scatterplot pada gambar di atas dapat diketahui bahwa titiktitik-titik tidak membentuk pola yang jelas. Sebagaimana terlihat, titik-titik itu menyebar di atas dan di bawah angka 0 pada sumbu Y. Jadi dapat disimpulkan bahwa tidak terjadi heterokedastisitas dalam model regresi. 


\section{A.8. Pengujian Hipotesis}

\section{a. Uji Signifikansi Parsial (Uji Statistik t)}

Dalam penelitian ini diajukan tiga hipotesis untuk mengetahui dan menganalisis pengaruh dua variabel bebas terhadap variabel terikat, yaitu:

- Hipotesis Pertama

Untuk menguji apakah terdapat pengaruh Penerapan EProcurement $\left(\mathrm{X}_{1}\right)$ terhadap Kinerja Lembaga $(\mathrm{Y})$

$\mathrm{H}_{0}: \mathrm{b}_{1}=0$ :Penerapan E-Procurement tidak berpengaruh positif dan signifikan terhadap Kinerja Lembaga.

$\mathrm{H}_{1}: \mathrm{b}_{1} \# 0$ : Penerapan E-Procurement berpengaruh positif dan signifikan terhadap Kinerja Lembaga

Jika thitung $>$ tabel, maka $\mathrm{H}_{0}$ ditolak dan konsekuensinya $\mathrm{H}_{1}$ diterima, demikian sebaliknya.

- Hipotesis Kedua

Untuk menguji apakah terdapat pengaruh Good Governance $\left(\mathrm{X}_{2}\right)$ terhadap Kinerja Lembaga $(\mathrm{Y})$

$\mathrm{H}_{0}: \mathrm{b}_{2}=0$ : Good Governance tidak berpengaruh positif dan signifikan terhadap Kinerja Lembaga. 
$\mathrm{H}_{1}: \mathrm{b}_{2} \# 0$ :Good Governance berpengaruh positif dan signifikan terhadap Kinerja Lembaga

Jika thitung $>$ tabel, maka $\mathrm{H}_{0}$ ditolak dan konsekuensinya $\mathrm{H}_{1}$ diterima, demikian sebaliknya.

- Hipotesis Ketiga

Dilakukan untuk menguji apakah terdapat pengaruh Penerapan E-Procurement $\left(\mathrm{X}_{1}\right)$ dan Good Governance $\left(\mathrm{X}_{2}\right)$ secara bersama-sama terhadap Kinerja Lembaga $(\mathrm{Y})$

$\mathrm{H}_{0}: \mathrm{b}_{3}=0$ :Penerapan E-Procurement dan Good Governance secara bersama-sama tidak berpengaruh positif dan signifikan terhadap Kinerja Lembaga.

$\mathrm{H}_{1}: \mathrm{b}_{3} \# 0$ : Penerapan E-Procurement dan Good Governance secara bersama-sama berpengaruh positif dan signifikan terhadap Kinerja Lembaga.

Apabila Fhitung > Ftabel, maka $\mathrm{H}_{0}$ ditolak dan konsekuensinya $\mathrm{H}_{1}$ diterima,demikian sebaliknya.

Adapun uji statistik $\mathrm{t}$ berguna untuk menguji pengaruh dari masing-masing variabel independen secara parsial terhadap variabel dependen. Untuk mengetahui ada tidaknya pengaruh 
masing-masing variabel independen secara parsial terhadap variabel dependen dapat dilihat pada tabel berikut di bawah ini. Hasil uji statistik $t$ dapat dilihat dengan kriteria jika nilai probability thitung $>$ tabel maka $\mathrm{H}_{1}$ diterima, sedangkan jika nilai probability thitung $<$ tabel maka $\mathrm{H}_{0}$ diterima.

Tabel 4.14.

\section{Hasil Uji Statistik t}

\begin{tabular}{|l|r|r|r|r|r|}
\hline \multirow{2}{*}{ Model } & \multicolumn{2}{|c|}{$\begin{array}{c}\text { Unstandardized } \\
\text { Coefficients }\end{array}$} & $\begin{array}{c}\text { Standardized } \\
\text { Coefficients }\end{array}$ & & \\
\cline { 2 - 6 } & \multicolumn{1}{|c|}{$\mathrm{B}$} & Std. Error & \multicolumn{1}{c|}{ Beta } & $\mathrm{t}$ & Sig. \\
\hline $1 \quad$ (Constant) & 5.122 & 5.725 & & .895 & .377 \\
Penerapan E_Procurement & .348 & .180 & .286 & 2.930 & .001 \\
Good Governance & .758 & .195 & .576 & 3.889 & .000 \\
\hline
\end{tabular}

Dengan melihat pada Tabel 4.14 diatas dapat diketahui tingkat signifikan untuk masing-masing variabel bebas. Adapun untuk hasil uji hipotesis sebagai berikut :

- Pengaruh Penerapan E-Procurement terhadap Kinerja Lembaga

Untuk mengetahui keberartian atau signifikansi pengaruh Penerapan E-Procurement $\left(\mathrm{X}_{1}\right)$ terhadap Kinerja Lembaga $(\mathrm{Y})$, nilai thitung yang diperoleh perlu terlebih dahulu dibandingkan dengan nilai $T_{\text {tabel. }}$ Dari tabel di atas diketahui bahwa nilai thitung yang diperoleh sebesar 2,930. Sedangkan nilai $T_{\text {tabel }}$ pada 
tingkat kepercayaan $95 \%(\alpha=5 \%)$ dengan degree of freedom $(\mathrm{df})=40$ adalah 2,021 .

Oleh karenanya, jika dibandingkan antara nilai thitung $(2,930)$ dan nilai $T_{\text {tabel }}(2,021)$, maka nilai thitung lebih besar daripada nilai tabel. Ini berarti Hipotesis nol $\left(\mathrm{H}_{0}\right)$ yang berbunyi : Tidak terdapat pengaruh positif dan signifikan Penerapan EProcurement terhadap Kinerja Lembaga pada Bagian Pengadaan Barang dan Jasa Sekretariat Daerah Kabupaten Pandeglang "ditolak"; dan Hipotesis alternatif $\left(\mathrm{H}_{1}\right)$ yang berbunyi : Terdapat pengaruh positif dan signifikan Penerapan E-Procurement terhadap Kinerja Lembaga pada Bagian Pengadaan Barang dan Jasa Sekretariat Daerah Kabupaten Pandeglang "diterima".

\section{- Pengaruh Good Governance terhadap Kinerja Lembaga}

Untuk mengetahui keberartian atau signifikansi pengaruh Good Governance $\left(\mathrm{X}_{2}\right)$ terhadap Kinerja Lembaga $(\mathrm{Y})$, nilai thitung yang diperoleh perlu terlebih dahulu dibandingkan dengan nilai $T_{\text {tabel. }}$ Dari tabel di atas diketahui bahwa nilai thitung yang diperoleh sebesar 3,889 . Sedangkan nilai $T_{\text {tabel }}$ pada tingkat kepercayaan $95 \%(\alpha=5 \%)$ dengan degree of freedom $(\mathrm{df})=40$ adalah 2,021. 
Oleh karenanya, jika dibandingkan antara nilai thitung $(3,889)$ dan nilai $T_{\text {tabel }}(2,021)$, maka nilai thitung lebih besar daripada nilai $T_{\text {tabel. }}$ Ini berarti Hipotesis nol $\left(\mathrm{H}_{0}\right)$ yang berbunyi : Tidak terdapat pengaruh positif dan signifikan Good Governance terhadap Kinerja Lembaga pada Bagian Pengadaan Barang dan Jasa Sekretariat Daerah Kabupaten Pandeglang "ditolak"; dan Hipotesis alternatif $\left(\mathrm{H}_{1}\right)$ yang berbunyi : Terdapat pengaruh positif dan signifikan Good Governance terhadap Kinerja Lembaga pada Bagian Pengadaan Barang dan Jasa Sekretariat Daerah Kabupaten Pandeglang "diterima".

\section{b. Uji Signifikan Simultan (Uji Statistik F)}

Uji statistik $\mathrm{F}$ bertujuan untuk mengetahui pengaruh secara bersama-sama atau simultan variabel independen terhadap variabel dependen atau terikat. Kriteria yang digunakan adalah apabila nilai $F_{\text {hitung }}>F_{\text {tabel }}$ maka $\mathrm{H}_{0}$ ditolak dan konsekuensinya $\mathrm{H}_{1}$ diterima, demikian sebaliknya. Adapun hasil analisis data, uji signifikan simultan (uji statistik F) dapat dilihat pada tabel berikut : 
Tabel 4.15. Hasil Uji Statistik F

\begin{tabular}{|ll|r|r|r|c|c|}
\hline Model & & Sum of Squares & df & Mean Square & F & Sig. \\
\hline 1 & Regression & 932.201 & 2 & 466.100 & 38.681 & $.000^{\mathrm{a}}$ \\
& Residual & 457.897 & 38 & 12.050 & & \\
Total & 1390.098 & 40 & & & \\
\hline
\end{tabular}

Untuk mengetahui keberartian atau signifikansi pengaruh Penerapan E-Procurement $\left(X_{1}\right)$ dan Good Governance $\left(X_{2}\right)$ secara bersama-sama terhadap Kinerja Lembaga $(Y)$ dilakukan dengan uji-F. Fhitung yang diperoleh perlu terlebih dahulu dibandingkan dengan nilai $F_{\text {tabel. }}$ Dari tabel di atas diketahui bahwa nilai $F_{\text {hitung }}$ yang diperoleh sebesar 38,681. Sedangkan nilai $F_{\text {tabel }}$ pada tingkat kepercayaan $95 \%(\alpha=5 \%)$ dengan degree of freedom $(\mathrm{df})=39$ adalah 3,238 .

Oleh karenanya, jika dibandingkan antara nilai $F_{\text {hitung }}$ $(38,681)$ dan nilai $F_{\text {tabel }}(3,238)$, maka nilai $F_{\text {hitung }}$ lebih besar daripada nilai $F_{\text {tabel. }}$ Ini berarti Hipotesis nol $\left(\mathrm{H}_{0}\right)$ yang berbunyi : Tidak terdapat pengaruh positif dan signifikan Penerapan EProcurement dan Good Governance secara bersama-sama terhadap Kinerja Lembaga pada Bagian Pengadaan Barang dan Jasa Sekretariat Daerah Kabupaten Pandeglang "ditolak"; dan Hipotesis alternatif $\left(\mathrm{H}_{1}\right)$ yang berbunyi : Terdapat pengaruh positif dan signifikan Penerapan E-Procurement dan Good Governance secara bersama-sama terhadap Kinerja Lembaga 
pada Bagian Pengadaan Barang dan Jasa Sekretariat Daerah Kabupaten Pandeglang "diterima".

\section{A.9 Analisis Jalur}

Berikutnya menganalisis pengaruh variabel-variabel bebas terhadap variabel terikat. Adapun analisis uji pengaruh melalui analisis jalur yang hasil perhitungannya dilakukan dengan menggunakan aplikasi SPSS for Windows ver. 22.00 dan hasilnya terlihat seperti dalam tabel berikut:

Tabel 4.16.

Matriks Koefisien Korelasi Variabel Penelitian

\begin{tabular}{|ll|r|r|r|}
\hline & & $\begin{array}{c}\text { Penerapan } \\
\text { E_Procurement }\end{array}$ & $\begin{array}{c}\text { Good } \\
\text { Governance }\end{array}$ & $\begin{array}{c}\text { Kinerja } \\
\text { Lembaga }\end{array}$ \\
\hline Penerapan E_Procurement & Pearson Correlation & 1 & $.578^{* *}$ & $.534^{* *}$ \\
& Sig. (2-tailed) & .000 & .000 \\
& $\mathrm{~N}$ & 41 & 41 & 41 \\
\hline Good Governance & Pearson Correlation & $.578^{* *}$ & 1 & $.199^{* *}$ \\
& Sig. (2-tailed) & .000 & & .000 \\
& $\mathrm{~N}$ & 41 & 41 & 41 \\
\hline Kinerja Lembaga & Pearson Correlation & $.534^{* *}$ & $.199^{* *}$ & 1 \\
& Sig. (2-tailed) & .000 & .000 & 41 \\
& $\mathrm{~N}$ & 41 & 41 & 41 \\
\end{tabular}

Apabila dilihat dari ukuran tingkat signifikansinya, tabel 4.16 di atas menunjukkan bahwa korelasi signifikansi di antara keempat variabel pada tingkat kepercayaan $\alpha=0,05$, adalah signifikan. Jika selanjutnya ingin dihitung berapa besar pengaruh dari variabel 
Penerapan E-Procurement dan Good Governance terhadap Kinerja Lembaga baik secara langsung maupun secara tidak langsung dapat dihitung besaran koefisien jalur seperti berikut ini:

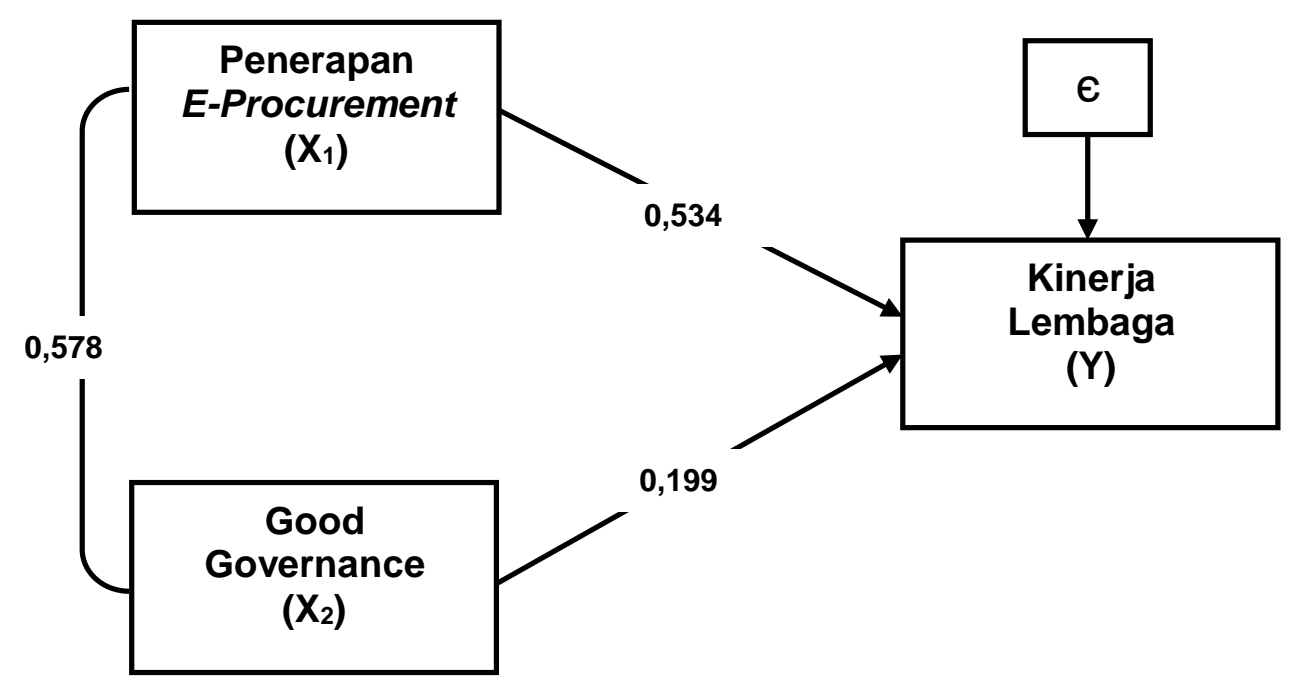

Gambar 4.5 Nilai Koefisien Jalur Variabel Penelitian

a) Besarnya pengaruh Penerapan E-Procurement $\left(X_{1}\right)$ terhadap Kinerja Lembaga $(Y)$ adalah sebagai berikut :

- Pengaruh langsung sebesar :

$\operatorname{ryx}_{1} \times \operatorname{ryx}_{1}=(0,534) \times(0,534)=0,2851$

- Pengaruh tidak langsung $\left(\mathrm{X}_{2}\right)$ sebesar :

$\operatorname{ryx}_{1} \times \operatorname{rx}_{1} x_{2} \times \operatorname{ryx}_{2}=(0,534) \times(0,578) \times(0,199)=0,061$

- Pengaruh total sebesar $=0,2851+0,061=0,3461$ 
Jadi pengaruh total dari Penerapan E-Procurement $\left(X_{1}\right)$ terhadap Kinerja Lembaga $(\mathrm{Y})$ adalah sebesar 34,61 \%.

b) Besarnya pengaruh Good Governance $\left(\mathrm{X}_{2}\right)$ terhadap Kinerja Lembaga $(\mathrm{Y})$ adalah :

- Pengaruh langsung sebesar :

$\operatorname{ryx}_{2} \times \operatorname{ryx}_{2}=(0,199) \times(0,199)=0,0396$

- Pengaruh tidak langsung $\left(X_{1}\right)$ sebesar :

$\operatorname{ryx}_{2} \times r_{2} x_{1} \times r_{y x}=(0,199) \times(0,578) \times(0,534)=0,061$

- Pengaruh total sebesar $=0,0396+0,061=0,1006$

Jadi pengaruh total dari Good Governance $\left(\mathrm{X}_{2}\right)$ terhadap Kinerja Lembaga $(Y)$ adalah sebesar 10,06\%.

Dari hasil perhitungan di atas, dapat diketahui bahwa variabel Kinerja Lembaga $(\mathrm{Y})$ dipengaruhi oleh variabel penerapan E-Procurement $\left(\mathrm{X}_{1}\right)$ Good Governance $\left(\mathrm{X}_{2}\right)$ secara bersama-sama sebesar $34,61 \%$. + 10,06 \%.= 44,67\%, sedangkan pengaruh variabel lain yang tidak diteliti sebesar $100 \%-44,67 \%=55,33 \%$. 


\section{B. PEMBAHASAN}

\section{B.1. Pengaruh Penerapan E-Procurement Terhadap Kinerja} Lembaga Pada Bagian Pengadaan Barang Dan Jasa Sekretariat Daerah Kabupaten Pandeglang

Dari hasil perhitungan pada pengolahan data penelitian diperoleh nilai thitung sebesar 2,930 sedangkan $T_{\text {tabel }}$ dengan derajat bebas (df) 40 pada a $(0,05)$ sebesar 2,021 , dengan demikian nilai thitung $>T_{\text {tabel, }}$ sehingga hipotesis yang diambil adalah Ho : ditolak dan $\mathrm{H}_{1}$ : diterima. Berdasarkan perhitungan tersebut maka pengujian hipotesis telah terbukti : Terdapat pengaruh positif dan signifikan Penerapan E-Procurement terhadap Kinerja Lembaga pada Bagian Pengadaan Barang dan Jasa Sekretariat Daerah Kabupaten Pandeglang.

Besar pengaruh Penerapan E-Procurement terhadap Kinerja Lembaga pada Bagian Pengadaan Barang dan Jasa Sekretariat Daerah Kabupaten Pandeglang sebesar 34,61 \%, yang terdiri dari pengaruh langsung sebesar $28,51 \%$ dan pengaruh tidak langsung sebesar $6,1 \%$.

Menurut Willem (2012:80) E-Procurement adalah merupakan pelaksanaan pengadaan barang dan jasa dengan menggunakan jaringan elektronik (jaringan internet atau intranet) atau electronic data interchange (EDI). Adapun dalam pelaksanaan kegiatan pengadaan sejak perencanaan harus menerapkan prinsip 
pengadaan barang dan jasa berdasarkan prinsip efisien, efektif, kompetitif, transparan dan bertangungjawab.

Menurut Sutedi (2012-254) manfaat dari pelaksanaan EProcurement adalah dengan E-Procurement proses lelang dapat berlangsung secara efektif, efisien, terbuka, besaing, transparan, adi/tidak diskriminatif dan akuntabel, sehingga diharapkan dapat mencerminkan keterbukaan/transparansi dan juga meminimalisir praktik curang/KKN dalam lelang pengadaan barang yang berakibat merugikan keuangan negara.

\section{B.2. Pengaruh Good Governance Terhadap Kinerja Lembaga Pada} Bagian Pengadaan Barang Dan Jasa Sekretariat Daerah Kabupaten Pandeglang

Dari hasil perhitungan pada pengolahan data penelitian diperoleh nilai thitung sebesar 3,889 sedangkan $T_{\text {tabel }}$ dengan derajat bebas (df) 40 pada a $(0,05)$ sebesar 2,021, dengan demikian nilai

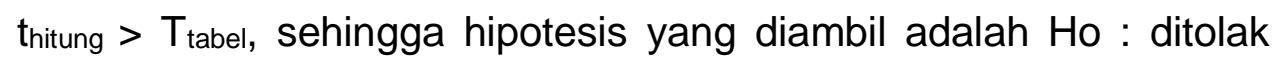
dan $\mathrm{H}_{1}$ : diterima. Berdasarkan perhitungan tersebut maka pengujian hipotesis telah terbukti : Terdapat pengaruh positif dan signifikan Good Governance terhadap Kinerja Lembaga pada Bagian Pengadaan Barang dan Jasa Sekretariat Daerah Kabupaten Pandeglang. 
Besar pengaruh Good Governance terhadap Kinerja Lembaga pada Bagian Pengadaan Barang dan Jasa Sekretariat Daerah Kabupaten Pandeglang sebesar 10,06 \%, yang terdiri dari pengaruh langsung sebesar 3,96 \% dan pengaruh tidak langsung sebesar $6,1 \%$.

Secara umum, governance diartikan sebagai kualitas hubungan antara pemerintah dan masyarakat yang dilayani dan dilindunginya, private sectors (sektor swasta/ dunia usaha), dan society (masyarakat). Oleh sebab itu, Good Governance sektor publik diartikan sebagai suatu proses tata kelola pemerintahan yang baik, dengan melibatkan stakeholders terhadap berbagai kegiatan perekonomian, sosial politik, dan pemanfaatan berbagai sumber daya seperti sumber daya alam, keuangan, dan manusia bagi kepentingan rakyat yang dilaksanakan dengan menganut asas keadialan, pemerataan, persamaan, efisiensi, transparansi, dan akuntabilitas (Sedarmayanti, 2007:2).

Jumlah komponen ataupun prinsip yang melandasi tata pemerintahan yang baik sangat bervariasi dari satu institusi ke institusi lain, dari satu pakar ke pakar lainnya. Namun paling tidak ada sejumlah prinsip yang dianggap sebagai prinsip- prinsip utama yang melandasi Good Governance, yaitu akuntabilitas, kejelasan dan ketersediaan, dan partisipasi (Sedarmayanti, 2009:289). 
B.3. Pengaruh Penerapan E-Procurement Dan Good Governance Secara Bersama-sama Terhadap Kinerja Lembaga Pada Bagian Pengadaan Barang Dan Jasa Sekretariat Daerah Kabupaten Pandeglang

Dari hasil perhitungan pada pengolahan data penelitian

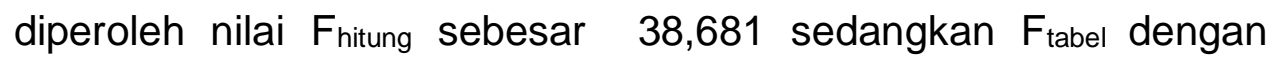
derajat bebas (df) 39 pada a $(0,05)$ sebesar 3,238, dengan demikian nilai $F_{\text {hitung }}>F_{\text {tabel, }}$ sehingga hipotesis yang diambil adalah $\mathrm{Ho}$ : ditolak dan $\mathrm{H}_{1}$ : diterima. Berdasarkan perhitungan tersebut maka pengujian hipotesis telah terbukti : Terdapat pengaruh positif dan signifikan Penerapan E-Procurement dan Good Governance secara bersama-sama terhadap Kinerja Lembaga pada Bagian Pengadaan Barang dan Jasa Sekretariat Daerah Kabupaten Pandeglang.

Besar pengaruh Penerapan E-Procurement dan Good Governance secara bersama-sama terhadap Kinerja Lembaga pada Bagian Pengadaan Barang dan Jasa Sekretariat Daerah Kabupaten Pandeglang sebesar 44,67\%.

Kinerja Lembaga adalah penampilan hasil karya pegawai baik kuantitas maupun kualitas dalam suatu organisasi. Penampilan hasil karya tidak terbatas kepada pegawai yang memangku jabatan fungsional maupun struktural, tetapi juga kepada keseluruhan jajaran pegawai di dalam organisasi. Dimensi kinerja menurut Gery Dessler (2004:57) meliputi : a. kualitas kerja (quality of output); b. 
kuantitas kerja (quantity of output); c. jumlah waktu kerja (time of work); d. kerjasama (corporation); e. supervisi (supervision).

Keberhasilan dalam mengelola barang/jasa, maka pada Bagian Pengadaan Barang dan Jasa Sekretariat Daerah Kabupaten Pandeglang perlu memperhitungkan aspek-aspek sesuai dengan hasil penelitian, yaitu perlunya memperhatikan faktor penerapan E-Procurement dan Good Governance. Kedua faktor tersebut dapat meningkatkan keberhasilan dalam mengefektifkan tata kelola barang dan jasa. 


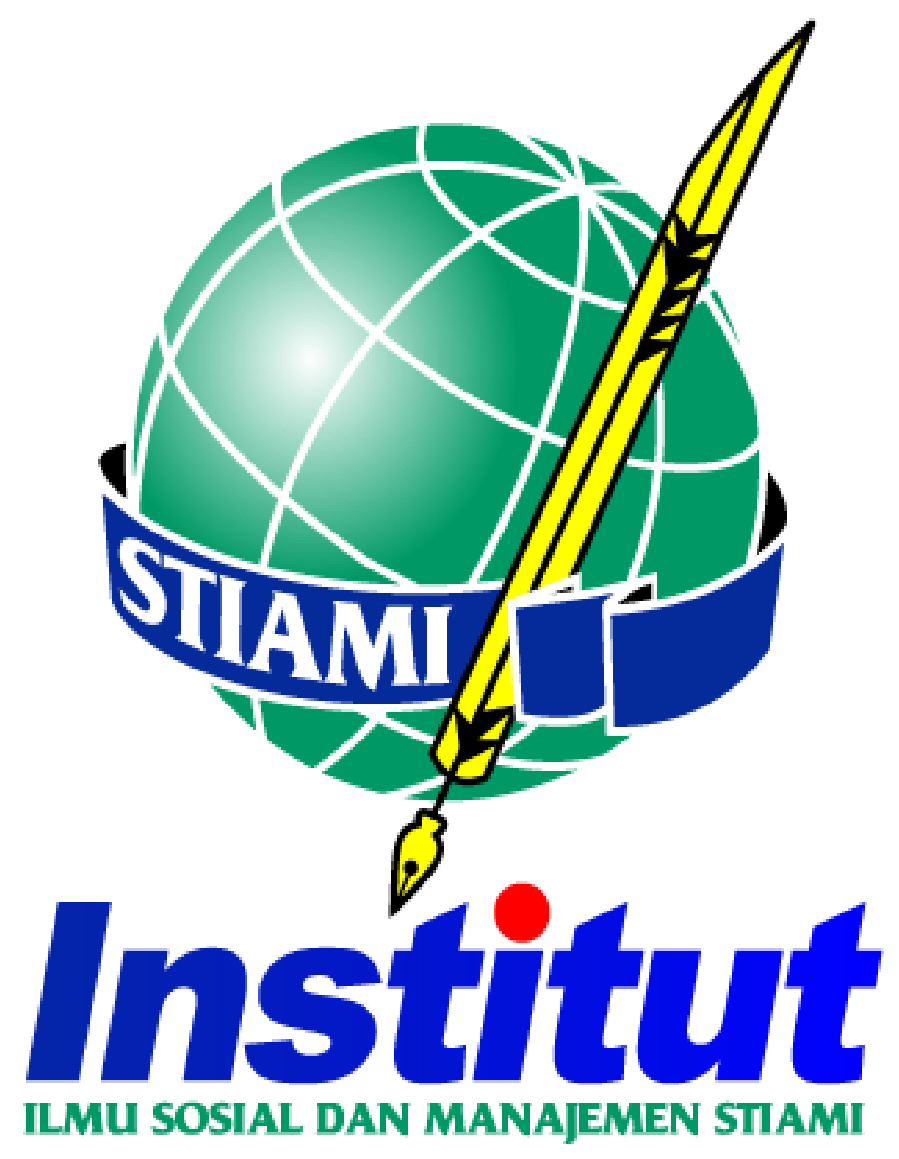




\section{BAB V}

\section{SIMPULAN DAN SARAN}

\section{A. Simpulan}

Berdasarkan hasil penelitian dan pembahasan pada bab IV mengenai pengaruh Penerapan E-Procurement dan Good Governance baik sendiri-sendiri maupun secara bersama-sama terhadap Kinerja Pengadaan Barang/Jasa pada Bagian Pengadaan Barang dan Jasa Sekretariat Daerah Kabupaten Pandeglang, maka simpulan dari penelitian ini adalah sebagai berikut :

1. Penerapan E-Procurement berpengaruh positif dan signifikan terhadap Kinerja Pengadaan Barang/Jasa pada Bagian Pengadaan Barang dan Jasa Sekretariat Daerah Kabupaten Pandeglang sebesar $34,61 \%$. Dengan kata lain, semakin baik Penerapan $E$ Procurement yang ada, maka Kinerja Pengadaan Barang/Jasa akan semakin meningkat.

2. Good Governance berpengaruh positif dan signifikan terhadap Kinerja Pengadaan Barang/Jasa pada Bagian Pengadaan Barang dan Jasa Sekretariat Daerah Kabupaten Pandeglang sebesar 10,06 \%. Dengan kata lain, semakin baik Good Governance yang ada, maka Kinerja Pengadaan Barang/Jasa akan semakin meningkat. 
3. Penerapan E-Procurement dan Good Governance secara bersamasama berpengaruh positif dan signifikan terhadap Kinerja Pengadaan Barang/Jasa pada Bagian Pengadaan Barang dan Jasa Sekretariat Daerah Kabupaten Pandeglang sebesar 44,67\%. Dengan kata lain, semakin baik Penerapan E-Procurement dan Good Governance, maka Kinerja Pengadaan Barang/Jasa akan semakin meningkat.

\section{B. Saran}

Dari hasil penelitian di atas, maka ada beberapa saran yang dapat penulis berikan, yaitu :

1. Untuk meningkatkan implementasi E-Procurement dapat diperhatikan beberapa faktor, yaitu efisien dalam penggunaan dana maupun fasilitas, efektif sesuai dengan kebutuhan, kompetitif dalam proses seleksi dan persaingan, transparan dalam penetapan calon penyedia barang/jasa, dan bertanggung jawab dalam pelaksanaan prinsip-prinsip dan kebijakan.

2. Adapun untuk upaya-upaya yang dapat dilakukan untuk meningkatkan Good Governance yaitu akuntabilitas dalam pembuatan keputusan, adanya kejelasan tugas dan kewenangan, proses penganggaran dilaksanakan secara terbuka, adanya keterlibatan dan peran aktif dari masyarakat. 
3. Sebaiknya dibuatkan peraturan daerah tentang pengadaan barang dan jasa supaya dilaksanakan secara online agar dapat diakses oleh masyarakat dan dilaksanakan secara transparan.

4. Diharapkan adanya penelitian lebih lanjut agar diketahui faktor lain yang mempengaruhi Kinerja Pengadaan Barang/Jasa selain faktor Penerapan E-Procurement dan Good Governance. 


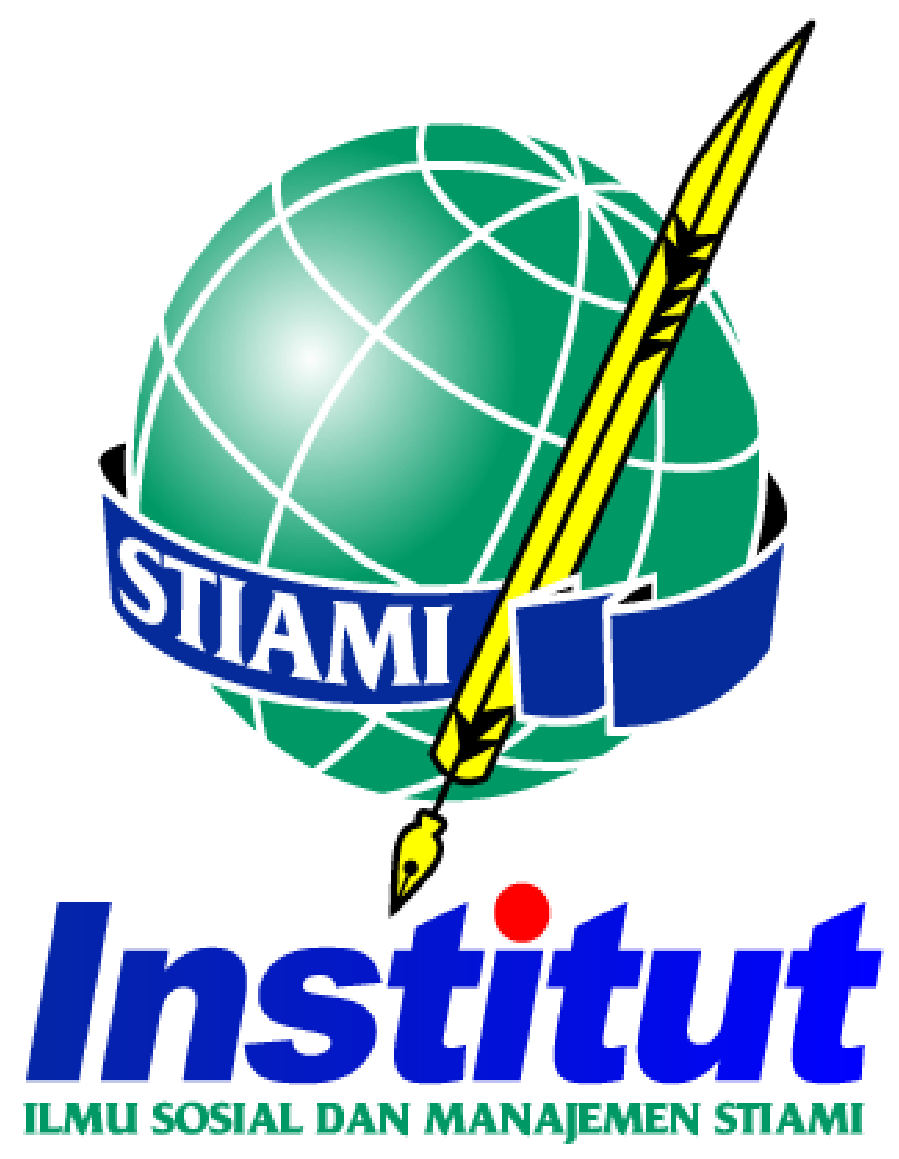




\section{DAFTAR PUSTAKA}

\section{Buku :}

Aditya, Dimas. 2014. Pengaruh E-Procurement dan Audit Ketaatan Terhadap Kewajaran Pelaporan Keuangan (Survey pada Dinas Cipta Karya dan Tata Ruang di Kabupaten Purwakarta). digilib.unpas.ac.id.

Adrian, Sutedi. 2012. Good Corporate Governance. Sinar Grafika.Jakarta.

Ar.Mustopadidjaja. 2003. Manajemen Proses Kebijakan Publik, Formulasi, Implementasi dan Evaluasi. Jakarta:Lembaga Administrasi Negara.

As'ad, Mohammad, 1995, Psikologi Industri, Yogyakarta: Liberty.

Badzlina Daroyani Novitaningrum, 2014, Akuntabilitas dan Transparansi Pengadaan Barang dan Jasa Pemerintah Melalui Electronic Procurement (Best Practice di Pemerintah Kota Surabaya), Kebijakan dan Manajemen Publik, Volume 2, Nomor 1, Januari 2014, ISSN 2303 -341X

Chandler, Ralph C.; Plano, Jack C. 2004. The Public Administration Dictionary, Santa Barbara, California: ABC-Clio.

Damayanti, Deni. 2014. Panduan Lengkap Menyusun Proposal, Skripsi, Disertasi.Yogyakarta: Alaska.

Dessler, Gerry, 2004, Manajemen Sumber Daya Manusia, Edisi Bahasa Indonesia. Jakarta: Prenhallindo.

Djojosoekarto, Agung, dkk, 2008, Kebijakan Otonomi Khusus Papua, Kemitraan bagi Pembaruan Tata Pemerintahan di Indonesia. Jakarta.

Ervianto, W. I. 2002. Teori Aplikasi Manajemen Proyek Konstruksi, Andi, Yogyakrta.

Falih Suaedi dan Bintoro Wardiyanto. 2010. Revitalisasi Administrasi Negara, Reformasi Birokrasi dan E-Governance. Yogyakarta: Graha IImu. 
Giri Sucahyo, Yudho Giri dkk. 2009. Inovasi Layanan Publik melalui E-Procurement, diambil dari Makalah Pembekalan Layanan Pengadaan Barang Secara Elektronik. Bappenas. Jakarta: LKPP.

Handayaningrat, Soewarno, 2002, Pengantar Studi IImu Administrasi dan Manajemen, Jakarta : Haji Masagung.

Hasibuan Malayu SP. 2006, Manajemen Sumber Daya Manusia, Jakarta:Bumi Aksara.

Irwan, Soehartono, 1999, Metode Penelitian Sosial, Jakarta : PT. Remaja Rosda Karya.

Keban, Yeremias T. 2008. Enam Dimensi Strategis Administrasi Publik: Konsep, Teori, Dan Isu. Yogyakarta: Gavamedia.

Kerlinger, F.N. \& Lee.H.B. 2000. Foundation of behavioral Research (Edisi Terjemahan). New York: Hartcourt College Publisher.

Koentjaraningrat. 1997. Kebudayaan, Mentalitas, dan Pembangunan. PT Gramedia Pustaka Utama. Jakarta.

Mangkunegara, A.A.P, 2007, Manajemen Sumber Daya Manusia dalam Perusahaan, Bandung : Remaja Rosdakarya

McMillan, J. H., \& Schumacher, S. 2006. Research in education: A conceptual introduction (5th ed.). New York: Longman.

Muhaimin, dkk 2010. Manajemen Pendidikan. Jakarta : Kencana Prenada Mulia Group.

Mondy, Sharplin and Flipo, Edwin, 1998, Personnel Management, Singapore : Mc. Graw Hill Inc.

Nawawi, Hadari,1994, "Ilmu Administrasi", Yogyakarta: Gajahmada University Press.

Pakpahan, A. 1989. Kerangka Analitik untuk Penelitian Rekayasa Sosial Perspektif Ekonomi Institusi. Prosiding Forum Agro Ekonomi. Bogor dalam Elizabeth, R dan Anugrah, IS. 2010. Kelembagaan Ekonomi pada Komunitas Petani Sayuran di Provinsi Bali. Prosiding Seminar Nasional. PESKP. Bogor.

Riduwan, 2003, Dasar-Dasar Statistika, Cetakan Ketiga, Bandung : Alfabeta. 
Saefulah, Djadja, 2005, Filsafat Administrasi, Bandung : Universitas Padjadjaran.

Saptana, dkk. 2003. Transformasi Kelembagaan Tradisional. PSEKP. Bogor.

Sedarmayanti, 2007, Sumber Daya Manusia dan Produktivitas Kerja, Bandung, Penerbit Mandar Maju.

. 2009. Reformasi Administrasi Publik, Reformasi Birokrasi, dan Kepemimpinan Masa Depan.Bandung: PT Refika Aditama.

Siagian, Sondang P, 1974, Administrasi Pembangunan, Jakarta : Gunung Agung.

Siahaya, Willem. 2012. Manajemen Pengadaan Procurement Management. Bandung: Alfabeta.

Simamora, Henry, 2007, Manajemen Sumber Daya Manusia, Edisi Kedua Yogyakarta : STIE YKPN

Sudaryanto, dkk. Pusat Penelitian dan Pengembangan Sosial Ekonomi Pertanian 2005. Laporan Akhir Pengkajian dan Pengembangan Model Operasional Percepatan Pemasyarakatan Inovasi Teknologi Pertanian Melalui Prima Tani?. PSEKP. Bogor.

Sugiyono. 2004. Metode Penelitian Bisnis. Jakarta : Rineka

Suprihanto, John, 2007, Manajemen Personalia (Pokok-Pokok, Kasus dan Soal Jawab),Yogyakarta : BPFE.

Suradisastra, dkk. Pusat Analisis Sosial Ekonomi dan Kebijakan Pertanian 2009. Laporan Hasil Penelitian Perumusan Model Kelembagaan Petani untuk Revitalisasi Kegiatan Ekonomi Perdesaan?. PSEKP. Bogor.

Uphoff, N. 1992. Local Institutions and Participation for Sustainable Development. Gatekeeper Series SA31. IIED, London.

Wibowo, S. Haryan, 2007, Pengukuran Kinerja Pegawai, Yogyakarta : Kanisius. 


\section{Jurnal :}

H. Rahadian. 2009. Memahami Konsep Tata Kelola Perusahaan Yang Sehat (Good Corporate Governance). Jurnal Bijak Vol.8 no.15;hal 75-90. Sekolah Tinggi IImu Administrasi Mandala Indonesia (STIAMI).

2010. Mewujudkan Good Governance Melalui Pelayanan Publik. Jurnal IImiah Sekolah Tinggi IImu Administrasi Mandala Indonesia (STIAMI)

H. Rahadian dan Irman Gapur. 2015. Pengaruh Sistem E-Procurement Dan Kompetensi Terhadap Kinerja Kantor Layanan Pengadaan Barang /Jasa Kabupaten Bogor. Jurnal IImu Sosial dan Manajemen : STIAMI Jakarta.

Andri Veno. 2015. The Influence of Good Corporate Governance toward Corporate Performance of Corporate Manufacture Go Public. Jurnal Manajemen dan Bisnis : Universitas Muhammadiyah Surakarta.

Mary Ismowati. 2016. Kajian Urgensi Public Private Partnerships Di Kota Bandung. Jurnal IImiah IImu administrasi : Institut IImu Sosial dan Manajemen STIAMI. . 2018. Pengaruh Kompetensi Pegawai Dan Iklim Organisasi Terhadap Kualitas Pelayanan Di Unit Pelaksana Pelayanan Terpadu Satu Pintu Kota Administrasi Jakarta Barat. Jurnal Transparansi : Institut IImu Sosial dan Manajemen STIAMI.

Lisa Oktaviani. 2017. The Effect of E-Procurement Against the Prevention and Detection of Fraud in the Public Sector procurement carried out in SKPD city of Padang, Solok, Pesisir Selatan. Universitas Negeri Padang.

Mahardika lintangsari, Dini Wahyu Hapsari, Eddy Budiono. 2017. The Effect of E-Procurement Implementation, Internal Control of Preventing Fraud (Empirical Study on PT. PLN (Persero) Distribution West Java and Banten). Telkom University. 
Maria Rofina. 2013. Pengaruh Penerapan Good Corporate Governance Terhadap Kinerja Keuangan Perusahaan Di BEI. Jurnal IImu dan Riset Akuntansi. STIESIA Surabaya.

Sulistyowati. 2017. Pengaruh Good Corporate Governance Terhadap Kinerja Keuangan Pada Perusahaan Perbankan. Jurnal IImu dan Riset Akuntansi. STIESIA Surabaya. 


\section{RIWAYAT HIDUP PENULIS}

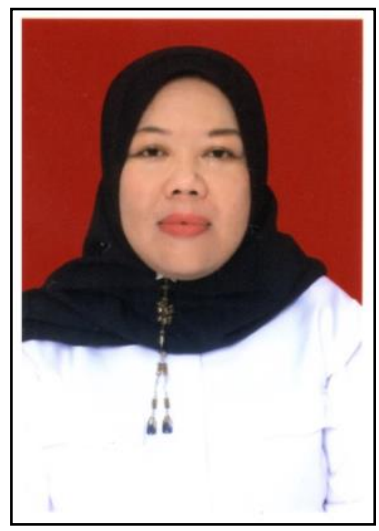

Penulis bernama LIA HERIAWATI,,lahir di Pandeglang pada tanggal 20 Mei 1979, Penulis merupakan anak ke dua dari tiga bersaudara dari pasangan suami istri Bapak Eri Azhari Kusumah dan Ibu Nining Bandiningsih (Alm)

Penulis berdomisili di Perumahan Kaduhejo Kadulisung Blok D No 21 desa Palurahan Kecamatan Kaduhejo Kabupaten Pandegng Provinsi Banten. Adapun riwayat pendidikan yang pernah ditempuh penulis adalah sebagai berikut :

1. SDN Nelayan I Labuan, lulus Tahun 1991

2. SMPN 1 Labuan,lulus Tahun 1994

3. SMUN 1 Labuan, Iulus Tahun 1997

4. AKADEMI SEKRETARI \& MANAJEMEN KENCANA Bandung, lulus tahun 2000

5. STISIP Banten Raya Pandeglang, lulus Tahun 2007

Sampai dengan Penulisasn tesis ini penulis masih terdaftar sebagai Mahasiswa Program Pascasarjana di Institut STIAMI Jakarta 


\section{A. LAMPIRAN 1 : ANGKET}

Kepada Yth, Bapak/lbu/Pegawai

Bagian Pengadaan Barang dan Jasa Sekretariat Daerah Kabupaten Pandeglang

di

Tempat

Assalamu'alaikum Wr.Wb.

Melalui kesempatan ini kami lampirkan angket yang terdiri dari tiga bagian/variabel. Adapun angket ini kami perlukan dalam rangka untuk memperoleh data guna penyusunan Tesis.

Dengan memperhatikan tujuan dari penyebaran angket ini yaitu adalah semata-mata untuk kepentingan akademis, maka silahkan merespon setiap item pernyataan dengan leluasa dan tanpa beban, dalam arti betul-betul sesuai dengan kondisi (pendapat, perasaan, pengalaman) yang sebenarnya.

\section{Hormat Kami}

\section{LIA HERIAWATI}

\section{Petunjuk Pengisian :}

Pilihlah salah satu jawaban yang anda anggap benar, dengan memberi tanda silang $(\mathrm{X})$ pada angka yang anda pilih.

Keterangan :

1. Sangat Tidak Setuju. (STS)

2. Tidak Setuju. (TS)

3. Kurang Setuju (KS)

4. Setuju. (S)

5. Sangat Setuju. (SS) 


\section{A. Penerapan Electronic Procurement $\left(\mathrm{X}_{1}\right)$}

\begin{tabular}{|c|c|c|c|c|c|c|}
\hline \multirow{2}{*}{ No } & \multirow{2}{*}{ Pernyataan } & \multicolumn{5}{|c|}{ Penilaian } \\
\hline & & 1 & 2 & 3 & 4 & 5 \\
\hline 1 & $\begin{array}{l}\text { Menurut anda, apakah proses pengadaan barang/jasa } \\
\text { dilakukan dengan dana yang sekecil kecilnya untuk } \\
\text { mencapai sasaran yang telah ditetapkan. }\end{array}$ & & & & & \\
\hline 2 & $\begin{array}{l}\text { Menurut anda, apakah proses pengadaan barang/jasa } \\
\text { dilakukan dengan daya yang sekecil kecilnya untuk } \\
\text { mencapai sasaran yang telah ditetapkan. }\end{array}$ & & & & & \\
\hline 3 & $\begin{array}{l}\text { Menurut anda, apakah proses pengadaan barang/jasa } \\
\text { dilakukan dengan fasilitas yang sekecil kecilnya untuk } \\
\text { mencapai sasaran yang telah ditetapkan. }\end{array}$ & & & & & \\
\hline 4 & $\begin{array}{l}\text { Menurut anda, apakah proses pengadaan barang/jasa } \\
\text { dilakukan sesuai dengan kebutuhan. }\end{array}$ & & & & & \\
\hline 5 & $\begin{array}{l}\text { Menurut anda, apakah proses pengadaan barang/jasa } \\
\text { dapat memberikan manfaat yang sebesar-besarnya } \\
\text { sesuai dengan sasaran yang ditetapkan. }\end{array}$ & & & & & \\
\hline 6 & $\begin{array}{l}\text { Proses pengadaan barang/jasa dilakukan melalui seleksi } \\
\text { dan persaingan yang sehat di antara penyedia } \\
\text { barang/jasa yang setara. }\end{array}$ & & & & & \\
\hline 7 & $\begin{array}{l}\text { Proses pengadaan barang/jasa sudah memenuhi } \\
\text { syarat/kriteria tertentu berdasarkan ketentuan dan } \\
\text { prosedur yang jelas serta transparan. }\end{array}$ & & & & & \\
\hline 8 & $\begin{array}{l}\text { Semua ketentuan dan informasi mengenai pengadaan } \\
\text { barang atau jasa bersifat terbuka. }\end{array}$ & & & & & \\
\hline 9 & $\begin{array}{l}\text { Administrasi pengadaan barang/jasa dilakukan secara } \\
\text { transparan dan akuntabel. }\end{array}$ & & & & & \\
\hline 10 & $\begin{array}{l}\text { Penetapan calon penyedia barang/jasa dilakukan secara } \\
\text { terbuka dan transparan. }\end{array}$ & & & & & \\
\hline 11 & $\begin{array}{l}\text { Bertanggung jawab dalam mencapai sasaran fisik } \\
\text { keuangan. }\end{array}$ & & & & & \\
\hline 12 & $\begin{array}{l}\text { Bertanggung jawab dalam pelaksanaan prinsip-prinsip dan } \\
\text { kebijakan. }\end{array}$ & & & & & \\
\hline
\end{tabular}




\section{B. Good Governance $\left(\mathrm{X}_{2}\right)$}

\begin{tabular}{|c|c|c|c|c|c|c|}
\hline \multirow{2}{*}{ No } & \multirow{2}{*}{ Pernyataan } & \multicolumn{5}{|c|}{ Penilaian } \\
\hline & & 1 & 2 & 3 & 4 & 5 \\
\hline 1 & $\begin{array}{l}\text { Menurut pendapat anda, apakah pembuatan } \\
\text { keputusan dilakukan secara tertulis dan terbuka. }\end{array}$ & & & & & \\
\hline 2 & $\begin{array}{l}\text { Menurut pendapat anda, apakah pembuatan } \\
\text { keputusan sudah memenuhi standar etika dan nilai- } \\
\text { nilai yang berlaku. }\end{array}$ & & & & & \\
\hline 3 & $\begin{array}{l}\text { Menurut pendapat anda, apakah terdapat kejelasan } \\
\text { dari sasaran kebijakan yang diambil dan sesuai } \\
\text { dengan visi dan misi organisasi. }\end{array}$ & & & & & \\
\hline 4 & $\begin{array}{l}\text { Pegawai memiliki konsistensi dari target operasional } \\
\text { yang telah ditetapkan dalam mencapai target. }\end{array}$ & & & & & \\
\hline 5 & $\begin{array}{l}\text { Menurut pendapat anda, apakah terdapat kejelasan } \\
\text { tugas dan wewenang. }\end{array}$ & & & & & \\
\hline 6 & $\begin{array}{l}\text { Menurut pendapat anda, apakah terdapat } \\
\text { ketersediaan informasi publik. }\end{array}$ & & & & & \\
\hline 7 & $\begin{array}{l}\text { Menurut pendapat anda, apakah proses } \\
\text { penganggaran dilakukan secara terbuka. }\end{array}$ & & & & & \\
\hline 8 & $\begin{array}{l}\text { Menurut pendapat anda, apakah terdapat jaminan } \\
\text { integritas dari kantor. }\end{array}$ & & & & & \\
\hline 9 & $\begin{array}{l}\text { Menurut pendapat anda, apakah terdapat keterlibatan } \\
\text { masyarakat dalam pengambilan keputusan. }\end{array}$ & & & & & \\
\hline 10 & $\begin{array}{l}\text { Masyarakat turut berperan aktif dalam menyampaikan } \\
\text { kritik dan saran kepada pemerintahan. }\end{array}$ & & & & & \\
\hline
\end{tabular}


C. Kinerja Lembaga ( $Y$ )

\begin{tabular}{|c|c|c|c|c|c|}
\hline \multirow{2}{*}{ No } & \multirow{2}{*}{ Pernyataan } & \multicolumn{4}{|c|}{ Penilaian } \\
\hline & & \begin{tabular}{|l|l|}
1 & 2 \\
\end{tabular} & 3 & 4 & 5 \\
\hline 1 & $\begin{array}{l}\text { Pegawai mengetahui adanya landasan religius dan } \\
\text { hukum pada Bagian Pengadaan Barang dan Jasa } \\
\text { Sekretariat Daerah Kabupaten Pandeglang. }\end{array}$ & & & & \\
\hline 2 & $\begin{array}{l}\text { Pegawai mengetahui kondisi geografis } \\
\text { demografis pada Bagian Pengadaan Barang } \\
\text { Jasa Sekretariat Daerah Kabupaten Pandeglang. }\end{array}$ & & & & \\
\hline 3 & $\begin{array}{l}\text { Pegawai bekerja lebih maksimal dalam rangka } \\
\text { mempersiapkan diri untuk menghadapi tantangan di } \\
\text { masa depan. }\end{array}$ & & & & \\
\hline 4 & $\begin{array}{l}\text { Pegawai mengetahui adanya visi dan misi pada } \\
\text { Bagian Pengadaan Barang dan Jasa Sekretariat } \\
\text { Daerah Kabupaten Pandeglang. }\end{array}$ & & & & \\
\hline 5 & $\begin{array}{l}\text { Sumber daya yang ada pada Bagian Pengadaan } \\
\text { Barang dan Jasa Sekretariat Daerah Kabupaten } \\
\text { Pandeglang sudah mencukupi. }\end{array}$ & & & & \\
\hline 6 & $\begin{array}{l}\text { Pimpinan dalam proses pengambilan keputusan } \\
\text { dilaksanakan sesuai dengan prosedur yang ada. }\end{array}$ & & & & \\
\hline 7 & $\begin{array}{l}\text { Proses pengelolaan program dapat dilaksanakan } \\
\text { dengan baik dan sesuai dengan rencana program. }\end{array}$ & & & & \\
\hline 8 & $\begin{array}{l}\text { Pegawai dapat mengevaluasi diri terhadap pekerjaan } \\
\text { yang telah dilaksanakan. }\end{array}$ & & & & \\
\hline 9 & $\begin{array}{l}\text { Pegawai dapat meningkatkan kinerja dalam rangka } \\
\text { memperoleh prestasi kerja yang lebih baik. }\end{array}$ & & & & \\
\hline 10 & $\begin{array}{l}\text { Kenaikan pangkat/golongan diberikan kepada } \\
\text { pegawai yang telah memenuhi persyaratan dan layak } \\
\text { untuk naik pangkat. }\end{array}$ & & & & \\
\hline 11 & $\begin{array}{l}\text { Pegawai mempunyai jenjang karier yang baik dalam } \\
\text { rangka meningkatkan pangkat/golongan. }\end{array}$ & & & & \\
\hline 12 & $\begin{array}{l}\text { Pegawai mempunyai peluang berkembang untuk } \\
\text { meningkatkan kinerja lembaga. }\end{array}$ & & & & \\
\hline & $\begin{array}{l}\text { Penghasilan yang diperoleh pegawai sudah memadai } \\
\text { dalam mencukupi kebutuhan hidup. }\end{array}$ & & & & \\
\hline
\end{tabular}


B. LAMPIRAN 2 : HASIL INPUT DATA

1. PENERAPAN E-PROCUREMENT $\left(X_{1}\right)$

\begin{tabular}{|c|c|c|c|c|c|c|c|c|c|c|c|c|c|}
\hline \multirow[b]{2}{*}{ NO } & \multicolumn{12}{|c|}{ Angket $X_{1}$} & \multirow[b]{2}{*}{$\mathrm{Jml}$} \\
\hline & 1 & 2 & 3 & 4 & 5 & 6 & 7 & 8 & 9 & 10 & 11 & 12 & \\
\hline 1 & 3 & 5 & 5 & 3 & 5 & 4 & 5 & 4 & 5 & 4 & 5 & 4 & 52 \\
\hline 2 & 3 & 3 & 4 & 3 & 3 & 5 & 5 & 4 & 3 & 4 & 3 & 5 & 45 \\
\hline 3 & 5 & 4 & 5 & 4 & 4 & 5 & 5 & 5 & 4 & 5 & 4 & 5 & 55 \\
\hline 4 & 3 & 4 & 4 & 3 & 4 & 5 & 4 & 3 & 3 & 4 & 4 & 5 & 46 \\
\hline 5 & 4 & 3 & 3 & 3 & 5 & 3 & 3 & 3 & 5 & 3 & 4 & 3 & 42 \\
\hline 6 & 3 & 4 & 3 & 3 & 4 & 4 & 4 & 3 & 4 & 3 & 4 & 4 & 43 \\
\hline 7 & 3 & 5 & 4 & 3 & 4 & 3 & 3 & 4 & 3 & 4 & 3 & 3 & 42 \\
\hline 8 & 4 & 5 & 4 & 5 & 5 & 5 & 3 & 3 & 3 & 4 & 4 & 5 & 50 \\
\hline 9 & 4 & 4 & 5 & 5 & 4 & 5 & 5 & 5 & 5 & 4 & 5 & 5 & 56 \\
\hline 10 & 4 & 4 & 4 & 3 & 4 & 5 & 4 & 5 & 4 & 4 & 4 & 5 & 50 \\
\hline 11 & 4 & 5 & 4 & 4 & 5 & 5 & 5 & 5 & 5 & 4 & 4 & 5 & 55 \\
\hline 12 & 3 & 4 & 3 & 4 & 4 & 3 & 4 & 3 & 4 & 3 & 4 & 3 & 42 \\
\hline 13 & 5 & 4 & 5 & 3 & 4 & 3 & 4 & 3 & 4 & 5 & 4 & 3 & 47 \\
\hline 14 & 5 & 5 & 5 & 5 & 5 & 5 & 5 & 5 & 5 & 5 & 5 & 5 & 60 \\
\hline 15 & 5 & 5 & 4 & 4 & 5 & 5 & 3 & 5 & 3 & 4 & 5 & 5 & 53 \\
\hline 16 & 3 & 3 & 3 & 4 & 4 & 5 & 5 & 5 & 4 & 3 & 4 & 5 & 48 \\
\hline 17 & 4 & 4 & 4 & 4 & 4 & 4 & 5 & 4 & 5 & 4 & 4 & 4 & 50 \\
\hline 18 & 5 & 4 & 5 & 4 & 5 & 3 & 3 & 3 & 5 & 5 & 5 & 3 & 50 \\
\hline 19 & 5 & 3 & 4 & 4 & 3 & 3 & 4 & 3 & 3 & 4 & 3 & 3 & 42 \\
\hline 20 & 3 & 4 & 4 & 3 & 3 & 4 & 5 & 3 & 4 & 4 & 3 & 4 & 44 \\
\hline 21 & 4 & 5 & 3 & 4 & 5 & 4 & 5 & 4 & 4 & 3 & 5 & 4 & 50 \\
\hline 22 & 3 & 4 & 4 & 3 & 3 & 4 & 3 & 4 & 3 & 4 & 5 & 4 & 44 \\
\hline 23 & 3 & 4 & 4 & 3 & 5 & 4 & 5 & 4 & 5 & 4 & 5 & 4 & 50 \\
\hline 24 & 5 & 5 & 4 & 5 & 5 & 5 & 5 & 5 & 5 & 4 & 5 & 5 & 58 \\
\hline 25 & 4 & 4 & 4 & 4 & 5 & 4 & 5 & 4 & 5 & 4 & 5 & 4 & 52 \\
\hline 26 & 5 & 5 & 3 & 5 & 4 & 3 & 5 & 5 & 3 & 5 & 4 & 3 & 50 \\
\hline 27 & 5 & 5 & 5 & 4 & 5 & 4 & 5 & 4 & 5 & 5 & 5 & 4 & 56 \\
\hline 28 & 5 & 4 & 3 & 4 & 5 & 5 & 3 & 5 & 3 & 3 & 5 & 5 & 50 \\
\hline 29 & 3 & 4 & 4 & 4 & 4 & 3 & 5 & 3 & 4 & 4 & 4 & 3 & 45 \\
\hline 30 & 5 & 3 & 5 & 4 & 4 & 4 & 5 & 4 & 4 & 5 & 4 & 4 & 51 \\
\hline 31 & 5 & 4 & 5 & 4 & 5 & 5 & 5 & 5 & 5 & 5 & 5 & 5 & 58 \\
\hline
\end{tabular}




\begin{tabular}{|c|c|c|c|c|c|c|c|c|c|c|c|c|c|}
\hline \multirow[b]{2}{*}{ NO } & \multicolumn{12}{|c|}{ Angket $X_{1}$} & \multirow[b]{2}{*}{$\mathrm{Jml}$} \\
\hline & 1 & 2 & 3 & 4 & 5 & 6 & 7 & 8 & 9 & 10 & 11 & 12 & \\
\hline 32 & 4 & 3 & 3 & 5 & 3 & 5 & 4 & 5 & 3 & 3 & 3 & 5 & 46 \\
\hline 33 & 3 & 5 & 4 & 4 & 4 & 4 & 4 & 4 & 4 & 4 & 4 & 4 & 48 \\
\hline 34 & 3 & 4 & 3 & 4 & 4 & 4 & 4 & 4 & 4 & 3 & 4 & 4 & 45 \\
\hline 35 & 4 & 4 & 4 & 5 & 5 & 3 & 5 & 3 & 5 & 4 & 5 & 3 & 50 \\
\hline 36 & 5 & 5 & 5 & 5 & 4 & 4 & 4 & 4 & 4 & 5 & 4 & 4 & 53 \\
\hline 37 & 4 & 4 & 4 & 4 & 4 & 4 & 4 & 4 & 4 & 4 & 4 & 4 & 48 \\
\hline 38 & 3 & 4 & 4 & 5 & 4 & 4 & 4 & 5 & 4 & 4 & 4 & 4 & 49 \\
\hline 39 & 4 & 3 & 4 & 3 & 3 & 5 & 3 & 4 & 3 & 4 & 3 & 5 & 44 \\
\hline 40 & 4 & 5 & 4 & 5 & 3 & 5 & 3 & 5 & 3 & 4 & 5 & 5 & 51 \\
\hline 41 & 5 & 5 & 5 & 5 & 5 & 4 & 5 & 4 & 5 & 5 & 4 & 4 & 56 \\
\hline Jml & 164 & 171 & 166 & 163 & 173 & 171 & 175 & 167 & 166 & 166 & 173 & 171 & 2026 \\
\hline Mean & 3.93 & 4.12 & 4.02 & 3.98 & 4.24 & 4.21 & 4.33 & 4.17 & 4.17 & 4.19 & 4.38 & 4.36 & 49.41 \\
\hline
\end{tabular}




\section{GOOD GOVERNANCE $\left(\mathrm{X}_{2}\right)$}

\begin{tabular}{|c|c|c|c|c|c|c|c|c|c|c|c|}
\hline \multirow[b]{2}{*}{ NO } & \multicolumn{10}{|c|}{ Angket $X_{2}$} & \multirow[b]{2}{*}{$\mathrm{Jml}$} \\
\hline & 1 & 2 & 3 & 4 & 5 & 6 & 7 & 8 & 9 & 10 & \\
\hline 1 & 3 & 4 & 5 & 4 & 3 & 5 & 4 & 3 & 3 & 4 & 38 \\
\hline 2 & 3 & 5 & 4 & 5 & 4 & 3 & 4 & 3 & 5 & 5 & 41 \\
\hline 3 & 5 & 5 & 4 & 5 & 3 & 3 & 5 & 4 & 5 & 4 & 43 \\
\hline 4 & 3 & 3 & 3 & 4 & 3 & 4 & 4 & 4 & 4 & 4 & 36 \\
\hline 5 & 3 & 3 & 4 & 3 & 4 & 4 & 3 & 4 & 3 & 3 & 34 \\
\hline 6 & 3 & 4 & 4 & 3 & 4 & 4 & 3 & 3 & 3 & 4 & 35 \\
\hline 7 & 3 & 5 & 3 & 4 & 3 & 3 & 4 & 4 & 3 & 3 & 35 \\
\hline 8 & 5 & 5 & 5 & 4 & 3 & 4 & 4 & 3 & 5 & 5 & 43 \\
\hline 9 & 4 & 5 & 3 & 4 & 5 & 3 & 4 & 5 & 3 & 4 & 40 \\
\hline 10 & 4 & 4 & 4 & 4 & 4 & 3 & 4 & 4 & 5 & 4 & 40 \\
\hline 11 & 5 & 5 & 5 & 4 & 5 & 4 & 4 & 5 & 5 & 5 & 47 \\
\hline 12 & 4 & 4 & 4 & 3 & 4 & 4 & 3 & 3 & 4 & 4 & 37 \\
\hline 13 & 4 & 4 & 4 & 5 & 4 & 4 & 5 & 5 & 5 & 5 & 45 \\
\hline 14 & 5 & 5 & 5 & 5 & 5 & 5 & 5 & 4 & 5 & 5 & 49 \\
\hline 15 & 5 & 5 & 5 & 4 & 5 & 5 & 4 & 5 & 5 & 3 & 46 \\
\hline 16 & 5 & 4 & 3 & 3 & 4 & 4 & 3 & 4 & 5 & 5 & 40 \\
\hline 17 & 4 & 4 & 3 & 4 & 4 & 3 & 4 & 5 & 4 & 5 & 40 \\
\hline 18 & 4 & 4 & 5 & 4 & 5 & 5 & 4 & 4 & 3 & 3 & 41 \\
\hline 19 & 3 & 3 & 3 & 4 & 3 & 3 & 4 & 3 & 5 & 5 & 36 \\
\hline 20 & 4 & 4 & 3 & 4 & 3 & 3 & 4 & 3 & 3 & 5 & 36 \\
\hline 21 & 5 & 5 & 5 & 3 & 5 & 5 & 3 & 5 & 4 & 5 & 45 \\
\hline 22 & 4 & 3 & 5 & 4 & 5 & 3 & 4 & 3 & 4 & 5 & 40 \\
\hline 23 & 4 & 4 & 5 & 4 & 5 & 5 & 4 & 5 & 4 & 5 & 45 \\
\hline 24 & 5 & 5 & 5 & 4 & 5 & 5 & 4 & 5 & 5 & 5 & 48 \\
\hline 25 & 4 & 4 & 5 & 4 & 5 & 5 & 4 & 5 & 4 & 5 & 45 \\
\hline 26 & 5 & 5 & 4 & 5 & 4 & 4 & 5 & 4 & 5 & 5 & 46 \\
\hline 27 & 3 & 5 & 3 & 5 & 5 & 3 & 5 & 5 & 4 & 5 & 43 \\
\hline 28 & 5 & 5 & 5 & 3 & 5 & 3 & 3 & 5 & 3 & 5 & 42 \\
\hline 29 & 4 & 4 & 4 & 4 & 4 & 4 & 4 & 4 & 3 & 5 & 40 \\
\hline 30 & 4 & 3 & 4 & 5 & 3 & 4 & 5 & 4 & 3 & 5 & 40 \\
\hline 31 & 5 & 5 & 5 & 5 & 5 & 5 & 5 & 5 & 5 & 5 & 50 \\
\hline 32 & 5 & 3 & 3 & 3 & 3 & 3 & 3 & 3 & 5 & 4 & 35 \\
\hline 33 & 5 & 4 & 5 & 4 & 5 & 4 & 4 & 5 & 4 & 4 & 44 \\
\hline 34 & 4 & 4 & 4 & 3 & 4 & 4 & 3 & 4 & 3 & 4 & 37 \\
\hline
\end{tabular}




\begin{tabular}{|c|c|c|c|c|c|c|c|c|c|c|c|}
\hline & \multicolumn{10}{|c|}{ Angket $\mathbf{X}_{\mathbf{2}}$} & \multirow{2}{*}{ NO } \\
\cline { 2 - 13 } & $\mathbf{1}$ & $\mathbf{2}$ & $\mathbf{3}$ & $\mathbf{4}$ & $\mathbf{5}$ & $\mathbf{6}$ & $\mathbf{7}$ & $\mathbf{8}$ & $\mathbf{9}$ & $\mathbf{1 0}$ & Jml \\
\hline 35 & 3 & 3 & 5 & 4 & 5 & 5 & 4 & 5 & 3 & 5 & 42 \\
\hline 36 & 4 & 5 & 4 & 5 & 4 & 4 & 5 & 4 & 4 & 4 & 43 \\
\hline 37 & 3 & 4 & 3 & 4 & 3 & 4 & 3 & 4 & 3 & 4 & 35 \\
\hline 38 & 4 & 3 & 4 & 4 & 3 & 4 & 4 & 4 & 4 & 4 & 38 \\
\hline 39 & 5 & 3 & 3 & 4 & 3 & 3 & 4 & 3 & 5 & 3 & 36 \\
\hline 40 & 5 & 5 & 5 & 4 & 5 & 5 & 4 & 5 & 5 & 5 & 48 \\
\hline 41 & 4 & 5 & 5 & 5 & 5 & 4 & 5 & 5 & 4 & 5 & 47 \\
\hline Jml & 169 & 172 & 170 & 166 & 169 & 162 & 164 & 170 & 167 & 182 & 1691 \\
\hline Mean & 4.05 & 4.14 & 4.12 & 4.05 & 4.14 & 4.00 & 4.07 & 4.24 & 4.19 & 4.57 & 41.24 \\
\hline
\end{tabular}




\section{KINERJA LEMBAGA (Y)}

\begin{tabular}{|c|c|c|c|c|c|c|c|c|c|c|c|c|c|c|}
\hline \multirow[b]{2}{*}{ No } & \multicolumn{13}{|c|}{ Angket $Y$} & \multirow[b]{2}{*}{$\mathrm{Jm}$} \\
\hline & 1 & 2 & 3 & 4 & 5 & 6 & 7 & 8 & 9 & 10 & 11 & 12 & 13 & \\
\hline 1 & 3 & 4 & 3 & 4 & 5 & 3 & 3 & 4 & 5 & 3 & 5 & 3 & 4 & 49 \\
\hline 2 & 4 & 4 & 5 & 3 & 3 & 4 & 5 & 3 & 3 & 4 & 3 & 4 & 3 & 48 \\
\hline 3 & 3 & 4 & 4 & 4 & 3 & 3 & 5 & 4 & 4 & 3 & 4 & 3 & 4 & 48 \\
\hline 4 & 3 & 4 & 3 & 4 & 3 & 4 & 4 & 3 & 4 & 3 & 4 & 3 & 4 & 46 \\
\hline 5 & 3 & 3 & 3 & 3 & 4 & 4 & 3 & 4 & 4 & 3 & 3 & 3 & 3 & 43 \\
\hline 6 & 4 & 4 & 3 & 4 & 4 & 3 & 3 & 3 & 4 & 3 & 4 & 3 & 4 & 46 \\
\hline 7 & 4 & 3 & 3 & 5 & 3 & 4 & 3 & 4 & 3 & 3 & 3 & 4 & 5 & 47 \\
\hline 8 & 5 & 5 & 5 & 4 & 5 & 4 & 5 & 5 & 4 & 5 & 4 & 5 & 5 & 61 \\
\hline 9 & 3 & 5 & 5 & 4 & 5 & 4 & 3 & 4 & 5 & 5 & 5 & 5 & 4 & 57 \\
\hline 10 & 4 & 3 & 4 & 3 & 3 & 4 & 5 & 4 & 4 & 3 & 4 & 3 & 4 & 48 \\
\hline 11 & 3 & 5 & 3 & 4 & 5 & 4 & 5 & 5 & 4 & 4 & 5 & 4 & 5 & 56 \\
\hline 12 & 3 & 4 & 3 & 3 & 4 & 3 & 4 & 3 & 4 & 3 & 4 & 3 & 3 & 44 \\
\hline 13 & 5 & 4 & 4 & 4 & 4 & 5 & 5 & 4 & 4 & 3 & 5 & 3 & 5 & 55 \\
\hline 14 & 4 & 5 & 5 & 5 & 4 & 5 & 5 & 4 & 4 & 5 & 4 & 5 & 5 & 60 \\
\hline 15 & 4 & 3 & 5 & 5 & 5 & 4 & 5 & 5 & 5 & 4 & 5 & 4 & 5 & 59 \\
\hline 16 & 5 & 5 & 5 & 3 & 4 & 3 & 5 & 4 & 3 & 4 & 3 & 4 & 3 & 51 \\
\hline 17 & 5 & 5 & 4 & 4 & 5 & 4 & 4 & 4 & 5 & 5 & 4 & 5 & 4 & 58 \\
\hline 18 & 5 & 3 & 3 & 4 & 5 & 4 & 3 & 5 & 5 & 4 & 5 & 4 & 4 & 54 \\
\hline 19 & 4 & 4 & 3 & 3 & 3 & 4 & 5 & 3 & 3 & 4 & 3 & 4 & 3 & 46 \\
\hline 20 & 3 & 5 & 5 & 4 & 3 & 4 & 3 & 5 & 3 & 3 & 3 & 3 & 4 & 48 \\
\hline 21 & 3 & 5 & 5 & 5 & 5 & 5 & 4 & 5 & 5 & 4 & 5 & 4 & 4 & 59 \\
\hline 22 & 5 & 5 & 4 & 5 & 5 & 5 & 4 & 5 & 5 & 3 & 5 & 3 & 4 & 58 \\
\hline 23 & 5 & 5 & 4 & 4 & 5 & 5 & 4 & 5 & 5 & 3 & 5 & 3 & 4 & 57 \\
\hline 24 & 5 & 5 & 5 & 5 & 5 & 4 & 5 & 5 & 5 & 5 & 5 & 5 & 5 & 64 \\
\hline 25 & 5 & 5 & 4 & 4 & 5 & 5 & 4 & 5 & 5 & 4 & 5 & 4 & 4 & 59 \\
\hline 26 & 4 & 5 & 5 & 5 & 4 & 3 & 5 & 3 & 4 & 3 & 4 & 5 & 3 & 53 \\
\hline 27 & 5 & 5 & 4 & 5 & 5 & 5 & 4 & 5 & 5 & 4 & 5 & 4 & 5 & 61 \\
\hline 28 & 5 & 5 & 5 & 5 & 5 & 3 & 3 & 5 & 5 & 4 & 5 & 4 & 4 & 58 \\
\hline 29 & 3 & 5 & 3 & 4 & 4 & 4 & 3 & 4 & 4 & 4 & 4 & 4 & 4 & 50 \\
\hline 30 & 3 & 5 & 4 & 3 & 4 & 5 & 4 & 4 & 4 & 4 & 4 & 4 & 3 & 51 \\
\hline 31 & 5 & 5 & 5 & 4 & 5 & 5 & 5 & 5 & 5 & 4 & 5 & 4 & 4 & 61 \\
\hline 32 & 3 & 4 & 5 & 3 & 3 & 3 & 5 & 3 & 3 & 5 & 3 & 5 & 3 & 48 \\
\hline 33 & 3 & 4 & 4 & 5 & 4 & 4 & 4 & 4 & 4 & 4 & 4 & 4 & 5 & 53 \\
\hline
\end{tabular}




\begin{tabular}{|c|c|c|c|c|c|c|c|c|c|c|c|c|c|c|}
\hline \multirow[b]{2}{*}{ NO } & \multicolumn{13}{|c|}{ Angket $\mathrm{Y}$} & \multirow[b]{2}{*}{$\mathrm{Jml}$} \\
\hline & 1 & 2 & 3 & 4 & 5 & 6 & 7 & 8 & 9 & 10 & 11 & 12 & 13 & \\
\hline 34 & 3 & 4 & 4 & 4 & 4 & 3 & 4 & 4 & 4 & 4 & 4 & 4 & 4 & 50 \\
\hline 35 & 5 & 5 & 3 & 4 & 5 & 4 & 3 & 5 & 5 & 5 & 5 & 5 & 4 & 58 \\
\hline 36 & 4 & 4 & 4 & 5 & 4 & 5 & 4 & 4 & 4 & 5 & 4 & 5 & 5 & 57 \\
\hline 37 & 4 & 4 & 4 & 4 & 4 & 4 & 4 & 4 & 4 & 4 & 4 & 4 & 4 & 52 \\
\hline 38 & 3 & 4 & 4 & 5 & 5 & 4 & 4 & 5 & 4 & 5 & 4 & 5 & 4 & 56 \\
\hline 39 & 3 & 3 & 5 & 3 & 3 & 4 & 5 & 3 & 3 & 3 & 3 & 3 & 3 & 44 \\
\hline 40 & 4 & 5 & 5 & 5 & 5 & 4 & 5 & 5 & 5 & 5 & 5 & 5 & 5 & 63 \\
\hline 41 & 4 & 5 & 4 & 5 & 5 & 5 & 4 & 5 & 4 & 5 & 4 & 5 & 5 & 60 \\
\hline $\mathrm{Jml}$ & 161 & 179 & 168 & 169 & 174 & 166 & 170 & 173 & 172 & 161 & 172 & 164 & 167 & 2196 \\
\hline Mean & 3.86 & 4.31 & 4.07 & 4.12 & 4.26 & 4.10 & 4.21 & 4.31 & 4.31 & 4.07 & 4.36 & 4.19 & 4.29 & 53.56 \\
\hline
\end{tabular}


C. LAMPIRAN 3 : HASIL UJI VALIDITAS DAN RELIABILITAS

\section{PENERAPAN E-PROCUREMENT $\left(X_{1}\right)$}

\begin{tabular}{|l|r|r|r|r|}
\hline & Item-Total Statistics & & Cronbach's \\
& $\begin{array}{c}\text { Scale Mean if } \\
\text { Item Deleted }\end{array}$ & $\begin{array}{c}\text { Scale Variance if } \\
\text { Item Deleted }\end{array}$ & $\begin{array}{c}\text { Corrected Item- } \\
\text { Total Correlation }\end{array}$ & $\begin{array}{c}\text { Alpha if Item } \\
\text { Deleted }\end{array}$ \\
\hline Pernyataan_1 & 45.41 & 19.449 & .461 & .754 \\
Pernyataan_2 & 45.24 & 20.539 & .394 & .761 \\
Pernyataan_3 & 45.37 & 20.088 & .469 & .754 \\
Pernyataan_4 & 45.44 & 20.152 & .415 & .759 \\
Pernyataan_5 & 45.20 & 20.011 & .464 & .754 \\
Pernyataan_6 & 45.24 & 20.689 & .323 & .769 \\
Pernyataan_7 & 45.15 & 20.628 & .310 & .771 \\
Pernyataan_8 & 45.34 & 19.680 & .465 & .753 \\
Pernyataan_9 & 45.37 & 20.038 & .397 & .761 \\
Pernyataan_10 & 45.37 & 20.438 & .440 & .757 \\
Pernyataan_11 & 45.20 & 19.911 & .514 & .749 \\
Pernyataan_12 & 45.24 & 20.689 & .323 & .769 \\
\hline
\end{tabular}

Reliability Statistics

\begin{tabular}{|r|r|}
\hline $\begin{array}{r}\text { Cronbach's } \\
\text { Alpha }\end{array}$ & N of Items \\
\hline .775 & 12 \\
\hline
\end{tabular}




\section{GOOD GOVERNANCE $\left(\mathrm{X}_{2}\right)$}

\begin{tabular}{|l|r|r|r|r|}
\hline & & & \\
& Scale Mean if & & Cronbach's \\
& Item Deleted & $\begin{array}{c}\text { Scale Variance if } \\
\text { Item Deleted }\end{array}$ & $\begin{array}{r}\text { Corrected Item- } \\
\text { Total Correlation }\end{array}$ & $\begin{array}{c}\text { Alpha if Item } \\
\text { Deleted }\end{array}$ \\
\hline Pernyataan_1 & 37.12 & 16.660 & .442 & .764 \\
Pernyataan_2 & 37.05 & 16.248 & .513 & .755 \\
Pernyataan_3 & 37.10 & 15.740 & .562 & .748 \\
Pernyataan_4 & 37.20 & 17.561 & .371 & .772 \\
Pernyataan_5 & 37.12 & 15.560 & .575 & .746 \\
Pernyataan_6 & 37.29 & 17.062 & .380 & .772 \\
Pernyataan_7 & 37.24 & 17.239 & .431 & .766 \\
Pernyataan_8 & 37.10 & 16.090 & .530 & .753 \\
Pernyataan_9 & 37.17 & 17.095 & .324 & .781 \\
Pernyataan_10 & 36.80 & 17.411 & .368 & .773 \\
\hline
\end{tabular}

\section{Reliability Statistics}

\begin{tabular}{|r|r|}
\hline \multicolumn{1}{|c|}{$\begin{array}{c}\text { Cronbach's } \\
\text { Alpha }\end{array}$} & N of Items \\
\hline .782 & 10 \\
\hline
\end{tabular}


3. KINERJA LEMBAGA (Y)

\begin{tabular}{|c|c|c|c|c|}
\hline & $\begin{array}{l}\text { Scale Mean if } \\
\text { Item Deleted }\end{array}$ & $\begin{array}{c}\text { Scale Variance if } \\
\text { Item Deleted }\end{array}$ & $\begin{array}{l}\text { Corrected Item- } \\
\text { Total Correlation }\end{array}$ & $\begin{array}{c}\text { Cronbach's } \\
\text { Alpha if Item } \\
\text { Deleted }\end{array}$ \\
\hline Pernyataan_1 & 49.63 & 29.788 & .458 & .839 \\
\hline Pernyataan_2 & 49.20 & 30.061 & .517 & .834 \\
\hline Pernyataan_3 & 49.46 & 31.355 & .318 & .848 \\
\hline Pernyataan_4 & 49.44 & 29.452 & .584 & .830 \\
\hline Pernyataan_5 & 49.32 & 27.922 & .733 & .819 \\
\hline Pernyataan_6 & 49.51 & 31.056 & .407 & .841 \\
\hline Pernyataan_7 & 49.41 & 33.699 & .346 & .865 \\
\hline Pernyataan_8 & 49.34 & 28.580 & .690 & .822 \\
\hline Pernyataan_9 & 49.37 & 29.538 & .605 & .829 \\
\hline Pernyataan_10 & 49.63 & 29.538 & .537 & .833 \\
\hline Pernyataan_11 & 49.37 & 29.088 & .632 & .827 \\
\hline Pernyataan_12 & 49.56 & 29.902 & .502 & .835 \\
\hline Pernyataan_13 & 49.49 & 29.906 & .549 & .832 \\
\hline
\end{tabular}

\section{Reliability Statistics}

\begin{tabular}{|r|r|}
\hline $\begin{array}{c}\text { Cronbach's } \\
\text { Alpha }\end{array}$ & N of Items \\
\hline .846 & 13 \\
\hline
\end{tabular}


D. LAMPIRAN 4 : HASIL OLAHAN DESKRIPTIF

1. PENERAPAN E-PROCUREMENT $\left(X_{1}\right)$

Statistics

Penerapan E-Procurement

\begin{tabular}{|l|r|}
\hline N $\quad$ Valid & 41 \\
\multicolumn{1}{|c|}{ Missing } & 0 \\
Mean & 49.41 \\
Median & 50.00 \\
Mode & 50 \\
Std. Deviation & 4.853 \\
Minimum & 42 \\
Maximum & 60 \\
\hline
\end{tabular}

Penerapan E-Procurement

\begin{tabular}{|c|c|c|c|c|c|}
\hline & & Frequency & Percent & Valid Percent & $\begin{array}{c}\text { Cumulative } \\
\text { Percent }\end{array}$ \\
\hline \multirow[t]{17}{*}{ Valid } & 42 & 4 & 9.8 & 9.8 & 9.8 \\
\hline & 43 & 1 & 2.4 & 2.4 & 12.2 \\
\hline & 44 & 3 & 7.3 & 7.3 & 19.5 \\
\hline & 45 & 3 & 7.3 & 7.3 & 26.8 \\
\hline & 46 & 2 & 4.9 & 4.9 & 31.7 \\
\hline & 47 & 1 & 2.4 & 2.4 & 34.1 \\
\hline & 48 & 3 & 7.3 & 7.3 & 41.5 \\
\hline & 49 & 1 & 2.4 & 2.4 & 43.9 \\
\hline & 50 & 9 & 22.0 & 22.0 & 65.9 \\
\hline & 51 & 2 & 4.9 & 4.9 & 70.7 \\
\hline & 52 & 2 & 4.9 & 4.9 & 75.6 \\
\hline & 53 & 2 & 4.9 & 4.9 & 80.5 \\
\hline & 55 & 2 & 4.9 & 4.9 & 85.4 \\
\hline & 56 & 3 & 7.3 & 7.3 & 92.7 \\
\hline & 58 & 2 & 4.9 & 4.9 & 97.6 \\
\hline & 60 & 1 & 2.4 & 2.4 & 100.0 \\
\hline & Total & 41 & 100.0 & 100.0 & \\
\hline
\end{tabular}


Berikut ini perhitungan distribusi frekuensi dengan menggunakan Rumus Sturges :

Nilai min $=42$

Nilai max

$=60$

Rentang (max - min)

$=18$

Banyaknya responden $(n)=41$

Banyaknya Kelas interval $=1+3,3 \log 41=6,32 \rightarrow 6$ atau 7

Panjang Kelas interval $(p)=18 / 7=2,57 \rightarrow 3$ atau 4

Maka distribusi frekuensi adalah sebagai berikut :

Perhitungan Distribusi Frekuensi Penerapan E-Procurement $\left(X_{1}\right)$

\begin{tabular}{|c|c|c|c|}
\hline No & Skor & Frekuensi & Prosentase (\%) \\
\hline 1 & $42-44$ & 8 & 19,51 \\
\hline 2 & $45-47$ & 6 & 14,63 \\
\hline 3 & $48-50$ & 13 & 31,71 \\
\hline 4 & $51-53$ & 6 & 14,63 \\
\hline 5 & $54-56$ & 5 & 12,20 \\
\hline 6 & $57-59$ & 2 & 4,88 \\
\hline 7 & $60-62$ & 1 & 2,44 \\
\hline \multicolumn{2}{|c|}{ JUMLAH } & $\mathbf{4 1}$ & $\mathbf{1 0 0 , 0 0}$ \\
\hline
\end{tabular}

Adapun untuk grafik histogram distribusi frekuensi sebagai berikut :

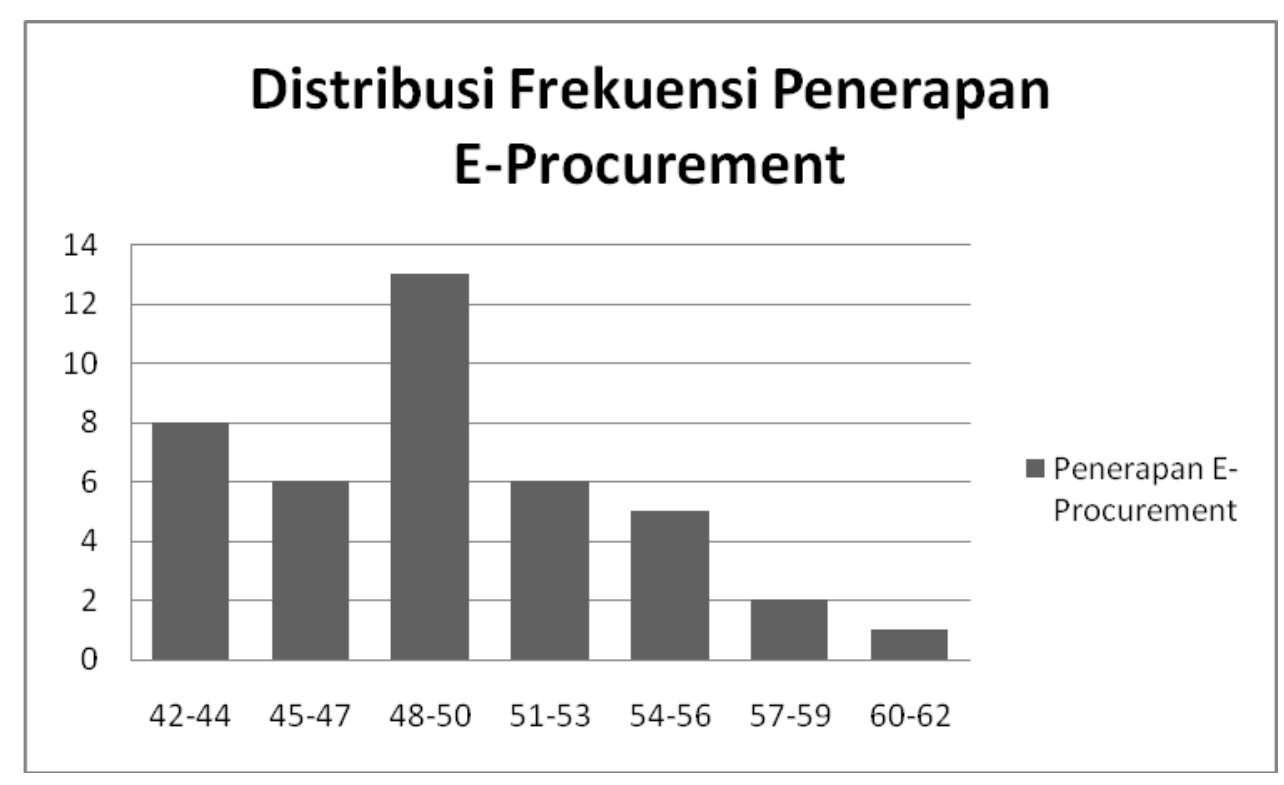




\section{GOOD GOVERNANCE $\left(\mathrm{X}_{2}\right)$}

\section{Statistics}

Good Governance

\begin{tabular}{|l|r|}
\hline N $\quad$ Valid & 41 \\
\multicolumn{1}{|c|}{ Missing } & 0 \\
Mean & 41.24 \\
Median & 41.00 \\
Mode & 40 \\
Std. Deviation & 4.482 \\
Minimum & 34 \\
Maximum & 50 \\
\hline
\end{tabular}

Good Governance

\begin{tabular}{|c|c|c|c|c|c|}
\hline & & Frequency & Percent & Valid Percent & $\begin{array}{c}\text { Cumulative } \\
\text { Percent }\end{array}$ \\
\hline \multirow[t]{17}{*}{ Valid } & 34 & 1 & 2.4 & 2.4 & 2.4 \\
\hline & 35 & 4 & 9.8 & 9.8 & 12.2 \\
\hline & 36 & 4 & 9.8 & 9.8 & 22.0 \\
\hline & 37 & 2 & 4.9 & 4.9 & 26.8 \\
\hline & 38 & 2 & 4.9 & 4.9 & 31.7 \\
\hline & 40 & 7 & 17.1 & 17.1 & 48.8 \\
\hline & 41 & 2 & 4.9 & 4.9 & 53.7 \\
\hline & 42 & 2 & 4.9 & 4.9 & 58.5 \\
\hline & 43 & 4 & 9.8 & 9.8 & 68.3 \\
\hline & 44 & 1 & 2.4 & 2.4 & 70.7 \\
\hline & 45 & 4 & 9.8 & 9.8 & 80.5 \\
\hline & 46 & 2 & 4.9 & 4.9 & 85.4 \\
\hline & 47 & 2 & 4.9 & 4.9 & 90.2 \\
\hline & 48 & 2 & 4.9 & 4.9 & 95.1 \\
\hline & 49 & 1 & 2.4 & 2.4 & 97.6 \\
\hline & 50 & 1 & 2.4 & 2.4 & 100.0 \\
\hline & Total & 41 & 100.0 & 100.0 & \\
\hline
\end{tabular}


Berikut ini perhitungan distribusi frekuensi dengan menggunakan Rumus Sturges :

Nilai min $=34$

Nilai max $=50$

Rentang (max $-\mathrm{min})=16$

Banyaknya responden $(n)=41$

Banyaknya Kelas interval $=1+3,3 \log 41=6,32 \rightarrow 6$ atau 7

Panjang Kelas interval $(p)=16 / 6=2,67 \rightarrow 3$ atau 4 Perhitungan Distribusi Frekuensi Good Governance $\left(\mathrm{X}_{2}\right)$

\begin{tabular}{|c|c|c|c|}
\hline No & Skor & Frekuensi & Prosentase (\%) \\
\hline 1 & $34-36$ & 9 & 21,95 \\
\hline 2 & $37-39$ & 4 & 9,76 \\
\hline 3 & $40-42$ & 11 & 26,83 \\
\hline 4 & $43-45$ & 9 & 21,95 \\
\hline 5 & $46-48$ & 6 & 14,63 \\
\hline 6 & $49-51$ & 2 & 4,88 \\
\hline \multicolumn{2}{|c|}{ JUMLAH } & $\mathbf{4 1}$ & $\mathbf{1 0 0 , 0 0}$ \\
\hline
\end{tabular}

Adapun untuk grafik histogram distribusi frekuensi sebagai berikut :

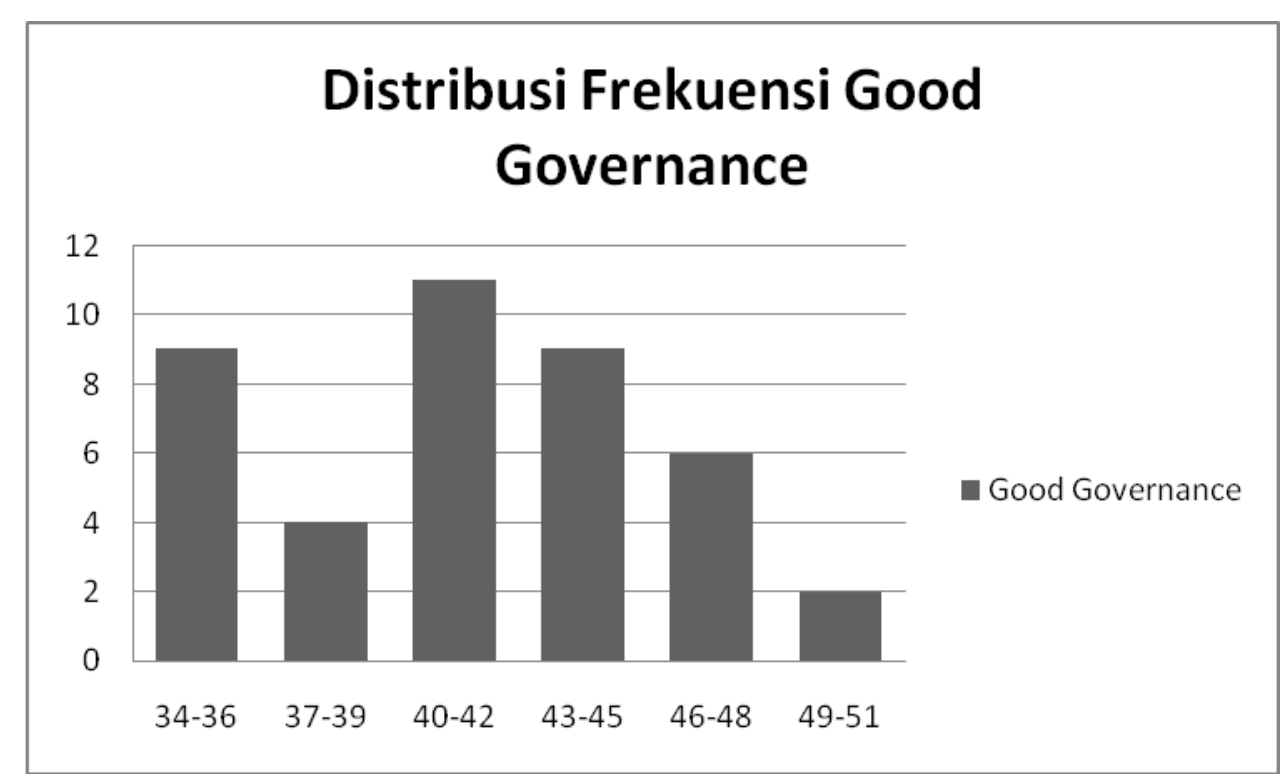


3. KINERJA LEMBAGA (Y)

\section{Statistics}

Kinerja Lembaga

\begin{tabular}{|l|r|}
\hline N $\quad$ Valid & 41 \\
\multicolumn{1}{|c|}{ Missing } & 0 \\
Mean & 53.56 \\
Median & 54.00 \\
Mode & 48 \\
Std. Deviation & 5.895 \\
Minimum & 43 \\
Maximum & 64 \\
\hline
\end{tabular}

Kinerja Lembaga

\begin{tabular}{|c|c|c|c|c|c|}
\hline & & Frequency & Percent & Valid Percent & $\begin{array}{l}\text { Cumulative } \\
\text { Percent }\end{array}$ \\
\hline \multirow[t]{21}{*}{ Valid } & 43 & 1 & 2.4 & 2.4 & 2.4 \\
\hline & 44 & 2 & 4.9 & 4.9 & 7.3 \\
\hline & 46 & 3 & 7.3 & 7.3 & 14.6 \\
\hline & 47 & 1 & 2.4 & 2.4 & 17.1 \\
\hline & 48 & 5 & 12.2 & 12.2 & 29.3 \\
\hline & 49 & 1 & 2.4 & 2.4 & 31.7 \\
\hline & 50 & 2 & 4.9 & 4.9 & 36.6 \\
\hline & 51 & 2 & 4.9 & 4.9 & 41.5 \\
\hline & 52 & 1 & 2.4 & 2.4 & 43.9 \\
\hline & 53 & 2 & 4.9 & 4.9 & 48.8 \\
\hline & 54 & 1 & 2.4 & 2.4 & 51.2 \\
\hline & 55 & 1 & 2.4 & 2.4 & 53.7 \\
\hline & 56 & 2 & 4.9 & 4.9 & 58.5 \\
\hline & 57 & 3 & 7.3 & 7.3 & 65.9 \\
\hline & 58 & 4 & 9.8 & 9.8 & 75.6 \\
\hline & 59 & 3 & 7.3 & 7.3 & 82.9 \\
\hline & 60 & 2 & 4.9 & 4.9 & 87.8 \\
\hline & 61 & 3 & 7.3 & 7.3 & 95.1 \\
\hline & 63 & 1 & 2.4 & 2.4 & 97.6 \\
\hline & 64 & 1 & 2.4 & 2.4 & 100.0 \\
\hline & Total & 41 & 100.0 & 100.0 & \\
\hline
\end{tabular}


Perhitungan distribusi frekuensi dengan menggunakan Rumus Sturges :

$\begin{array}{ll}\text { Nilai min } & =43 \\ \text { Nilai max } & =64 \\ \text { Rentang }(\max -\min ) & =21 \\ \text { Banyaknya responden }(\mathrm{n}) & =41 \\ \text { Banyaknya Kelas interval } & =1+3,3 \log 41=6,32 \rightarrow 6 \text { atau } 7 \\ \text { Panjang Kelas interval }(\mathrm{p}) & =21 / 6=3,5 \rightarrow 3 \text { atau } 4 \\ \text { Perhitungan Distribusi Frekuensi Kinerja Lembaga }(\mathrm{Y})\end{array}$

\begin{tabular}{|c|c|c|c|}
\hline No & Skor & Frekuensi & Prosentase (\%) \\
\hline 1 & $43-46$ & 6 & 14,63 \\
\hline 2 & $47-50$ & 9 & 21,95 \\
\hline 3 & $51-54$ & 6 & 14,63 \\
\hline 4 & $55-58$ & 10 & 24,39 \\
\hline 5 & $59-62$ & 8 & 19,51 \\
\hline 6 & $63-66$ & 2 & 4,88 \\
\hline \multicolumn{2}{|c|}{ JUMLAH } & $\mathbf{4 1}$ & $\mathbf{1 0 0 , 0 0}$ \\
\hline
\end{tabular}

Adapun untuk grafik histogram distribusi frekuensi sebagai berikut :

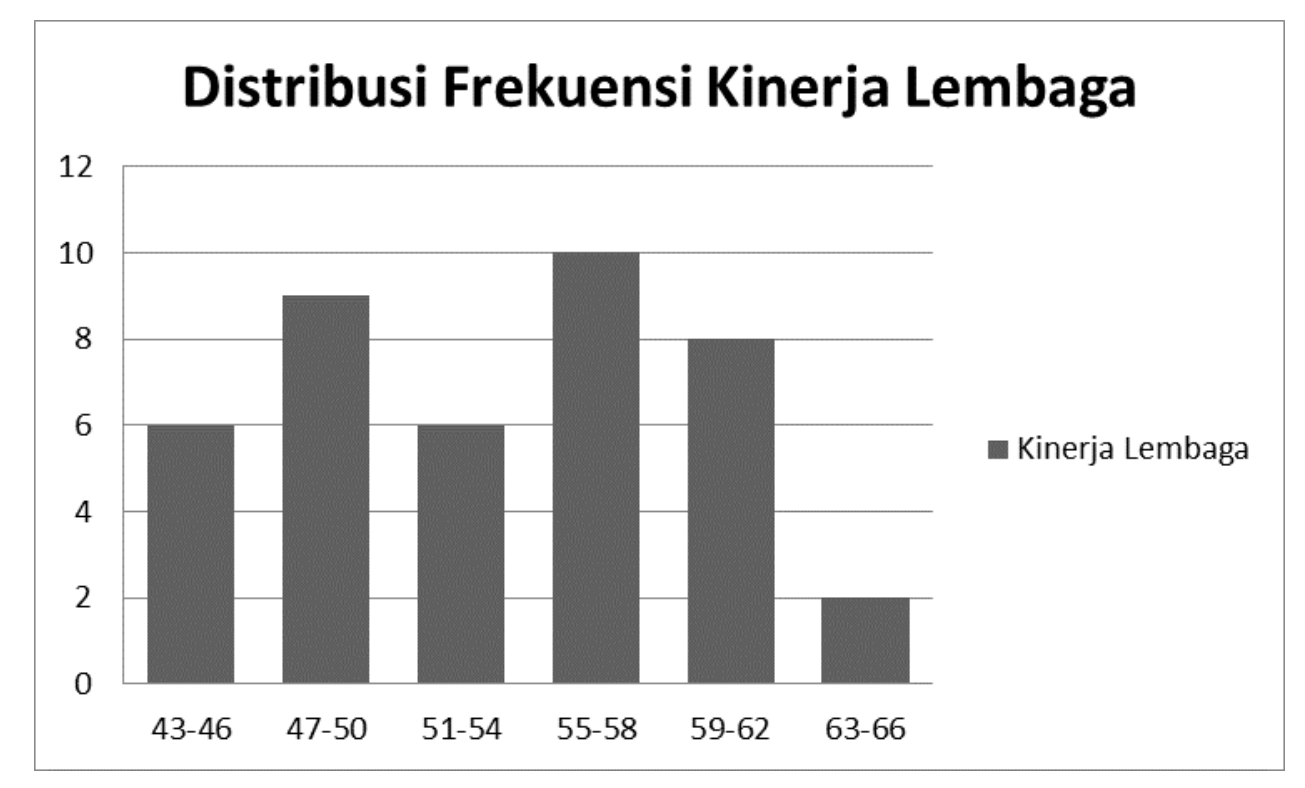


E. LAMPIRAN 5 : HASIL MSI DATA

\begin{tabular}{|c|c|c|}
\hline $\mathbf{X 1}$ & $\mathbf{X 2}$ & $\mathbf{Y}$ \\
\hline 31,34 & 19,36 & 24,74 \\
\hline 22,59 & 22,86 & 23,30 \\
\hline 34,58 & 25,29 & 23,37 \\
\hline 23,99 & 17,06 & 21,25 \\
\hline 19,06 & 14,34 & 17,65 \\
\hline 20,06 & 15,39 & 20,98 \\
\hline 19,51 & 16,07 & 22,60 \\
\hline 29,06 & 25,12 & 38,55 \\
\hline 35,82 & 21,54 & 34,21 \\
\hline 28,48 & 21,22 & 23,47 \\
\hline 34,58 & 29,50 & 33,12 \\
\hline 19,02 & 17,54 & 18,57 \\
\hline 25,24 & 27,59 & 31,60 \\
\hline 40,83 & 32,19 & 37,64 \\
\hline 32,57 & 28,31 & 36,64 \\
\hline 25,90 & 21,17 & 26,47 \\
\hline 28,41 & 21,59 & 35,01 \\
\hline 29,20 & 22,64 & 30,64 \\
\hline 18,98 & 17,16 & 21,04 \\
\hline 21,40 & 17,27 & 23,67 \\
\hline 28,56 & 26,90 & 36,76 \\
\hline 21,85 & 21,49 & 35,36 \\
\hline 28,74 & 27,20 & 34,13 \\
\hline 38,18 & 30,67 & 42,32 \\
\hline 31,02 & 27,20 & 36,47 \\
\hline 28,74 & 28,80 & 29,12 \\
\hline 36,05 & 25,46 & 38,98 \\
\hline 28,64 & 23,52 & 35,19 \\
\hline 22,82 & 21,61 & 25,93 \\
\hline 29,74 & 22,20 & 26,99 \\
\hline 38,33 & 33,37 & 38,80 \\
\hline 23,44 & 15,47 & 23,25 \\
\hline 26,33 & 25,92 & 29,36 \\
\hline 22,40 & 17,61 & 25,57 \\
\hline 28,84 & 23,96 & 35,29 \\
\hline & & \\
\hline 29
\end{tabular}




\begin{tabular}{|c|c|c|}
\hline $\mathbf{X 1}$ & $\mathbf{X 2}$ & $\mathbf{Y}$ \\
\hline 32,33 & 25,23 & 34,04 \\
\hline 26,10 & 15,77 & 27,93 \\
\hline 27,39 & 19,22 & 32,80 \\
\hline 21,50 & 17,11 & 18,81 \\
\hline 30,23 & 30,67 & 41,30 \\
\hline 35,91 & 29,94 & 37,72 \\
\hline
\end{tabular}

\section{F. LAMPIRAN 6 : HASIL OLAHAN UJI PERSYARATAN}

\section{Uji Normalitas Data}

Tests of Normality

\begin{tabular}{|l|r|r|r|r|r|r|}
\hline & \multicolumn{4}{|c|}{ Kolmogorov-Smirnova } & \multicolumn{3}{c|}{ Shapiro-Wilk } \\
\cline { 2 - 6 } & Statistic & df & \multicolumn{1}{c|}{ Sig. } & Statistic & \multicolumn{1}{c|}{ df } & \multicolumn{1}{c|}{ Sig. } \\
\hline Penerapan E_Procurement & .111 & 41 & $.200^{*}$ & .959 & 41 & .144 \\
Good Governance & .099 & 41 & $.200^{*}$ & .955 & 41 & .106 \\
Kinerja Lembaga & .135 & 41 & .059 & .948 & 41 & .060 \\
\hline
\end{tabular}

a. Lilliefors Significance Correction

*. This is a lower bound of the true significance.

\section{Uji Multikolinearitas Data}

\section{Coefficients $^{\mathrm{a}}$}

\begin{tabular}{|c|c|c|c|c|c|c|c|}
\hline \multirow[b]{2}{*}{ Model } & \multicolumn{2}{|c|}{$\begin{array}{c}\text { Unstandardized } \\
\text { Coefficients }\end{array}$} & \multirow{2}{*}{$\begin{array}{c}\begin{array}{c}\text { Standardized } \\
\text { Coefficients }\end{array} \\
\text { Beta }\end{array}$} & \multirow[b]{2}{*}{$\mathrm{t}$} & \multirow[b]{2}{*}{ Sig. } & \multicolumn{2}{|c|}{$\begin{array}{l}\text { Collinearity } \\
\text { Statistics }\end{array}$} \\
\hline & $\mathrm{B}$ & Std. Error & & & & Tolerance & VIF \\
\hline $1 \quad$ (Constant) & 5.122 & 5.725 & & .895 & .377 & & \\
\hline Penerapan E_Procurement & .348 & .180 & .286 & 2.930 & .001 & .395 & 2.533 \\
\hline Good Governance & .758 & .195 & .576 & 3.889 & .000 & .395 & 2.533 \\
\hline
\end{tabular}

a. Dependent Variable: Kinerja Lembaga 
3. Uji Autokorelasi

Model Summaryb

\begin{tabular}{|l|r|r|r|r|r|}
\hline Model & $\mathrm{R}$ & R Square & \multicolumn{1}{c|}{$\begin{array}{c}\text { Adjusted R } \\
\text { Square }\end{array}$} & $\begin{array}{c}\text { Std. Error of the } \\
\text { Estimate }\end{array}$ & Durbin-Watson \\
\hline 1 & $.819^{\mathrm{a}}$ & .671 & .653 & 3.471 & 1.852 \\
\hline
\end{tabular}

a. Predictors: (Constant), Good Governance, Penerapan E_Procurement

b. Dependent Variable: Kinerja Lembaga

\section{Uji Heterokedastisitas}

Scatterplot

Dependent Variable: Kinerja Pegawai

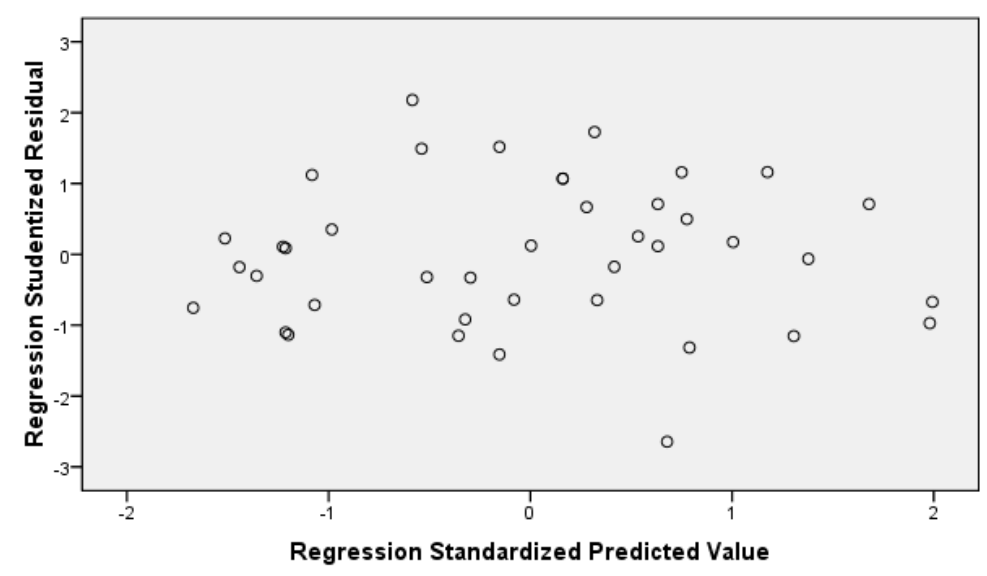




\section{G. LAMPIRAN 7 : HASIL UJI F dan KORELASI}

ANOVA $^{b}$

\begin{tabular}{|c|c|c|c|c|c|c|}
\hline \multicolumn{2}{|c|}{ Model } & Sum of Squares & $\mathrm{df}$ & Mean Square & $F$ & Sig. \\
\hline 1 & Regression & 932.201 & 2 & 466.100 & 38.681 & $.000^{\circ}$ \\
\hline & Residual & 457.897 & 38 & 12.050 & & \\
\hline & Total & 1390.098 & 40 & & & \\
\hline
\end{tabular}

a. Predictors: (Constant), Good Governance, Penerapan E_Procurement

b. Dependent Variable: Kinerja Lembaga

\begin{tabular}{|ll|r|r|r|}
\hline \multicolumn{2}{|c|}{ Correlations } & \multicolumn{1}{c|}{$\begin{array}{c}\text { Penerapan } \\
\text { E_Procurement }\end{array}$} & $\begin{array}{c}\text { Good } \\
\text { Governance }\end{array}$ & $\begin{array}{c}\text { Kinerja } \\
\text { Lembaga }\end{array}$ \\
\hline Penerapan E_Procurement & Pearson Correlation & 1 & $.578^{* *}$ & $.534^{* *}$ \\
& Sig. (2-tailed) & .000 & .000 \\
& $\mathrm{~N}$ & 41 & 41 & 41 \\
\hline Good Governance & Pearson Correlation & $.578^{* *}$ & .000 & $.199^{* *}$ \\
& Sig. (2-tailed) & 41 & .000 \\
$\mathrm{~N}$ & Pearson Correlation & $.534^{* *}$ & 41 & 41 \\
\hline Sig. (2-tailed) & .000 & $.199^{* *}$ & .000 & 1 \\
\hline $\mathrm{N}$ & 41 & 41 & 41 \\
\hline
\end{tabular}

${ }^{* *}$. Correlation is significant at the 0.01 level (2-tailed). 


\title{
H. LAMPIRAN HASIL TRANSLATE ABSTRACT
}

\author{
TRANSLATION \\ ABSTRACT \\ The Influence of E-Procurement and Good Governance Implementation \\ toward The Performance of Goods/Services Procurement in Division of Goods and Services \\ Procurement of Regional Secretary \\ in Pandeglang Regency \\ Lia Heriawati
}

This research aims to know and understand about how big the influence of EProcurement's Implementation is toward Performance of Goods/ Services Procurement, and to know and understand how big the influence of Good Governance's implementation toward The Performance of Procurement of Goods/Services, and to know and understand about how big the influence of E-Procurement and Good Governance's Implementation collectively toward The Performance of Procurement of Goods/Services.

Method that is used in this research is qualitative method of regression analysis to see how big the influence of independent variable and dependent variable are. Population of this research is all of employees in Division of Procurement of Goods and Services of Regional Secretary in Pandeglang Regency in total of 41 people. The Determination of sample is using a total sampling technique, therefore the amount of sample that is used in total of 41 responder. Each responder is given about 35 statements with using Likert scale. Data analysis is using qualitative analysis with linear regression test and double, test $\mathrm{t}$, test $\mathrm{F}$, correlation test and determination.

Based on the result from data management shows that The Implementation of EProcurement has a positive impact and significant toward The Performance of Procurement of 
Goods/Services in total of $34,61 \%$.. Thereafter Good Governance has a positive impact and significant toward The Performance of Procurement of Goods and Services in total of $10,06 \%$. Whereas The Implementation of E-Procurement and Good Governance are having a positive impact and significant collectively toward The Performance of Procurement of Goods/Services in total of $44,67 \%$. This matter shows that the better of E-Procurement's implementation is and Good Governance, thereafter the more Performance of procurement Goods/Services increases.

Key words : Implementation of E-Procurement, good Services, and Performance of Procurement Goods/ Services.

Reg no. 1032 /AR1/ Tx/2018 


\section{PEMERINTAH KABUPATEN PANDEGLANG SEKRETARIAT DAERAH}

Jalan Bhayangkara No. o5 Pandeglang Kode Pos 42213

Telpon (0253) 201403 Pesawat 10-32, Faks : (0253) 203800 www.setda.pandeglang.go.id, email : setda@pandeglangkab.go.id

Nomor : 005/ $278-\mathrm{Um} / 2018$

Lamp : -

Perihal : Penelitian dan Pengambilan Data
Pandeglang, 10 Mei 2018

Kepada

Yth. Kepala Bagian Pengadaan Barang dan Jasa SETDA Kabupaten Pandeglang

di-

\section{PANDEGLANG}

Menindaklanjuti surat dari STIAMI Nomor :060/PRO/MIA/Inst-STIAMI /SP/IP/V/2018 tanggal 04 Mei 2018 perihal Penelitian dan Pengambilan data di Bagian Pengadaan Barang dan Jasa Setda Kabupatan Pandeglang, untuk itu dimohon untuk dapat memberikan informasi yang dibutuhkan sebagai bahan/ data dalam penelitian oleh mahasiswa tersebut dibawah ini:
Nama : Lia Heriawati
NPM : bc 41621043
Judul : Pengaruh Penerapan Electronic Procurement dan Good Governance Terhadap Kinerja Pengadaan Barang dan Jasa Sekretariat Daerah Kabupaten Pandeglang
Waktu : dari Bulan Mei s/d Bulan Oktober 2018
Demikian surat pengantar ini dibuat atas kerjasamanya kami bsampaikan

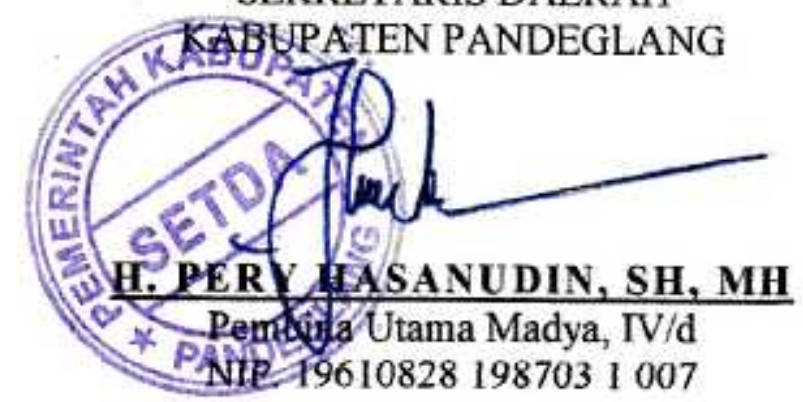
terimakasih. 


\section{BERITA ACARA UJIAN THESIS \\ No.301/D/Inst-STIAMI/UT/XX/2018}

Pada hari ini 20 Oktober 2018 bertempat di Ruang Sidang Kampus Institut IImu Sosial dan Manajemen STIAMI, JI.Letjend. Suprapto No. 504A Cempaka Putih Jakarta Pusat, telah dilaksanakan Ujian Thesis.

Nama : Lia Heriawati

NPM : : BC416212043

Konsentrasi : Administrasi Publik

Judul : Pengaruh Penerapan Elektronik Procuroment dan Good Governance terhadap kinerja Pengadaan barang ijasa pada bagian Pengadaan Barang jasa Sckretariat Daerah Kabupaten Pandeglang

Keputusan

Nilai

$$
81 \text { (A) }
$$

Jakarta, 20 Oktober 2018

Jakatan

Nama

Ketua Sidang

Dr. Bambang Irawan, M.Si, M.M

Penguji Ahli

Prof. Dr. A. Ramadhan Siregar, MS

Pembirmbing

Dr. Mary Ismowati, M.Si

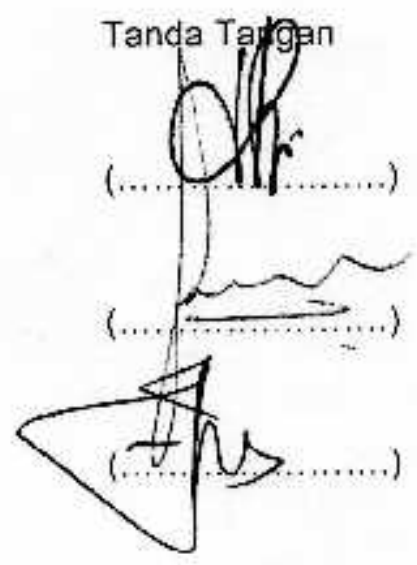

Mengetahui,

\section{Dr. Taufan Maulamin, SE, Akt, M.M}

Direktur Program 


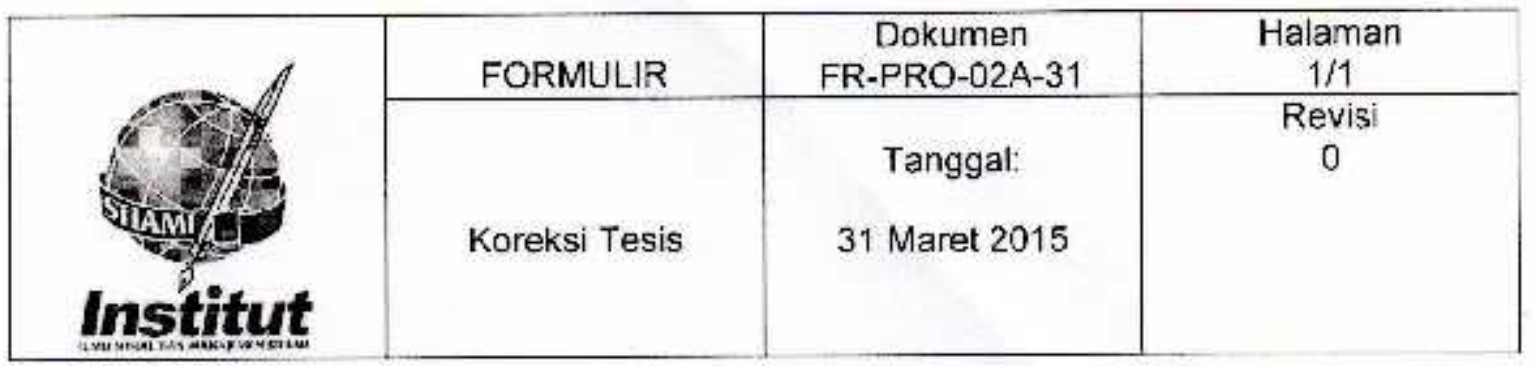

\section{FORM KOREKSI TESIS}

Nam a : Lia Heriawati

NPM $\quad: B C 416212043$

Konsentrasi : Administrasi Publik

Judul : Pengaruh Penerapan Elektronik Procuroment dan Good Governance terhadap kinerja Pengadaan barang /jasa pada bagian Pengadaan Barang jasa Sekretariat Daerah Kabupaten Pandeglang

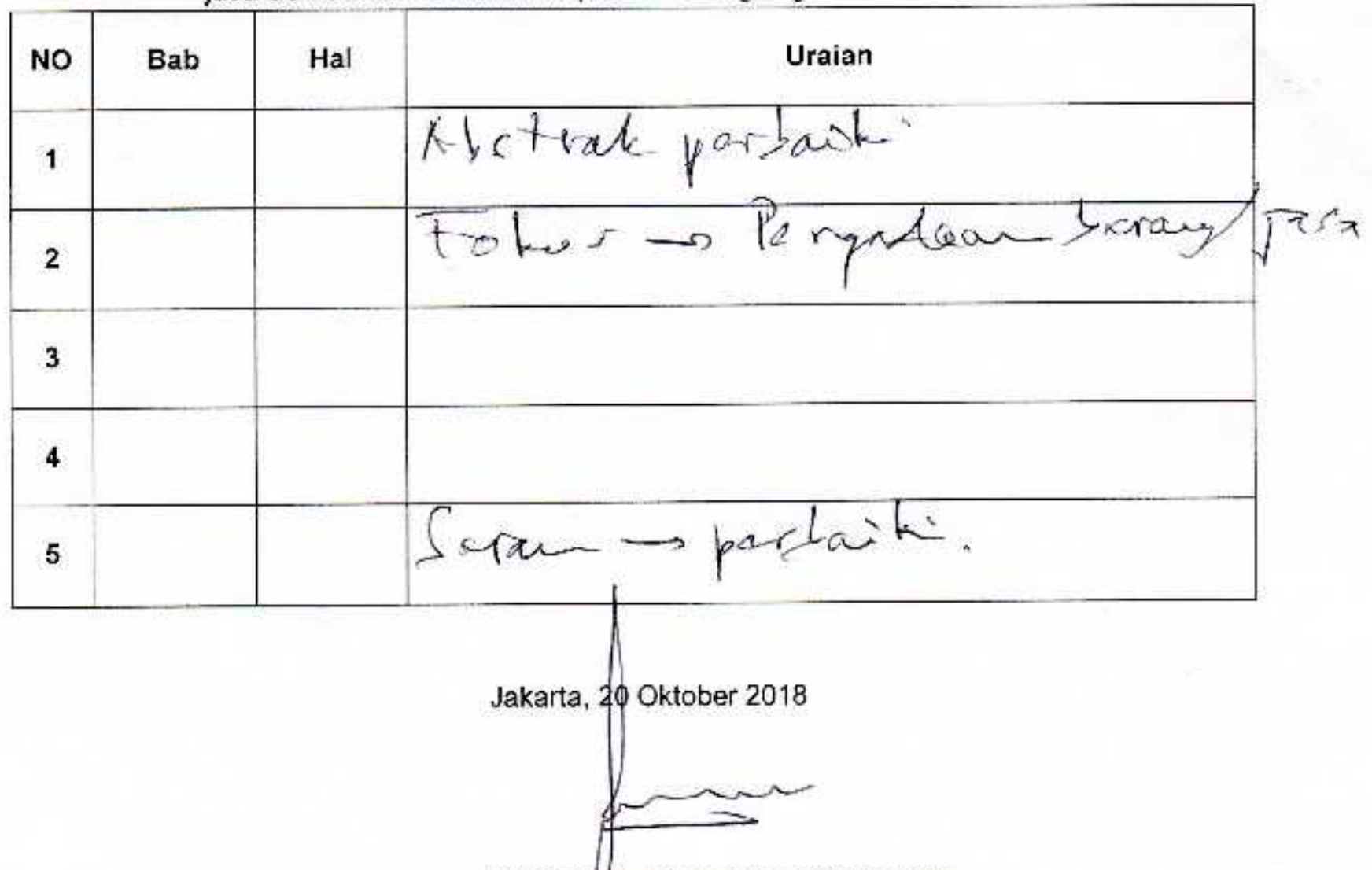

Prof. Dr.A. Ramadhan Siregar, MS

Penguji Ahli 


\begin{tabular}{|c|c|c|c|}
\hline \multirow{2}{*}{ FORMULIR } & Dokumen & $\begin{array}{c}\text { Halaman } \\
1 / 1\end{array}$ \\
\cline { 2 - 4 } & & FR-PRO-02A-31 & Revisi \\
Instifyt & & Tanggal: & 0 \\
\hline
\end{tabular}

\section{FORM KOREKSI TESIS}

Nama Lia Heriawati

NPM :BC416212043

Konsentrasi : Administrasi Publik

Judul : Pengaruh Penerapan Elektronik Procuroment dan Good Governance terhadap kinerja Pengadaan barang /jasa pada bagian Pengadaan Barang jasa Sekretariat Daerah Kabupaten Pandeglang

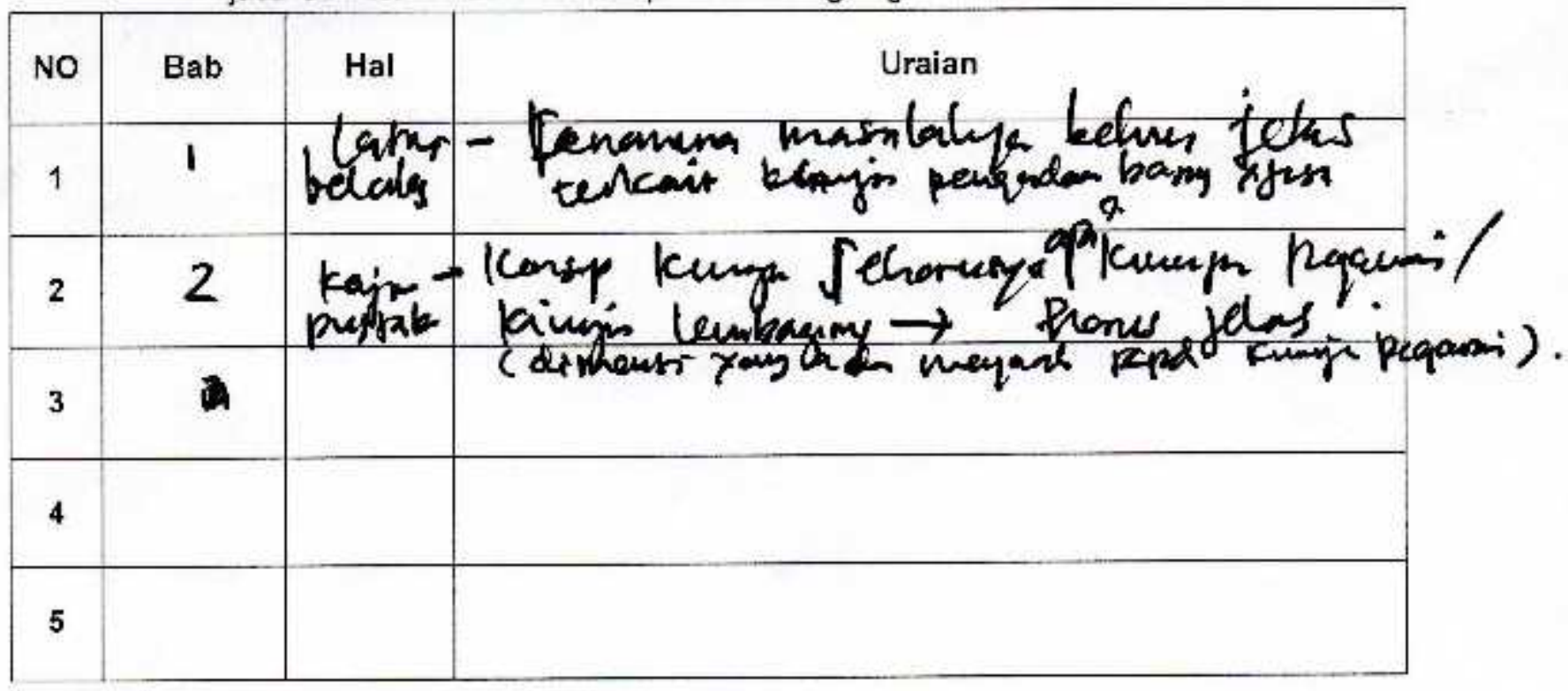

Jakarta, 20 Oktober 2018

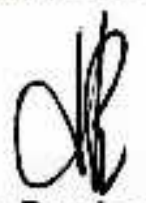

Dr. Bambang Irawan, M.Si, M.M

Ketua Penguji 


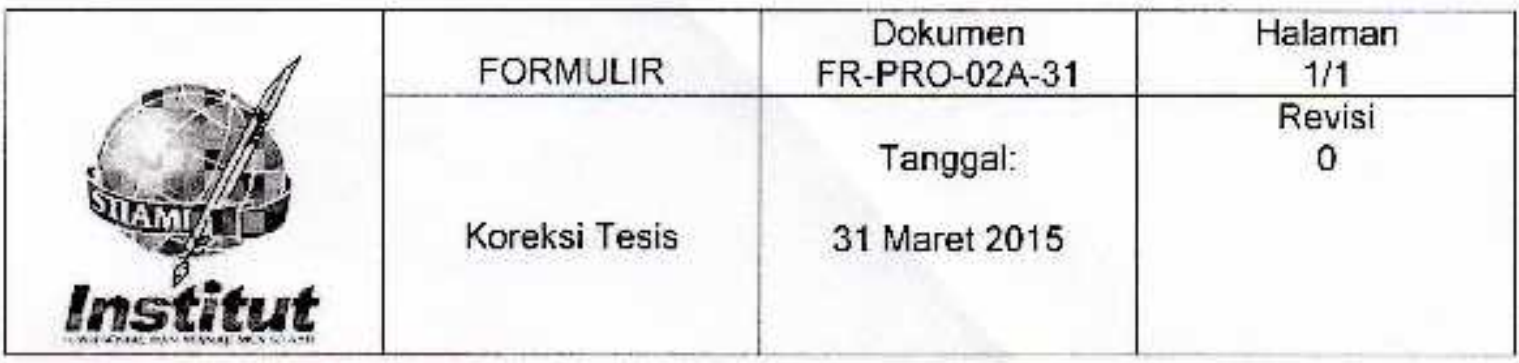

\section{FORM KOREKSI TESIS}

Nama $\quad$ : Lia Heriawati

NPM $\quad: B C 416212043$

Konsentrasi : Administrasi Publik

Judul : Pengaruh Penerapan Elektronik Procuroment dan Good Governance terhadap kinerja Pengadaan barang /jasa pada bagian Pengadaan Barang jasa Sekretariat Daerah Kabupaten Pandeglang

\begin{tabular}{|c|c|c|c|}
\hline No & Bab & Hal & Uraian \\
\hline 1 & & & \\
\hline 2 & & & \\
\hline 3 & & & \\
\hline 4 & & & \\
\hline 5 & & & \\
\hline
\end{tabular}

Jakarta, 20 Oktober 2018

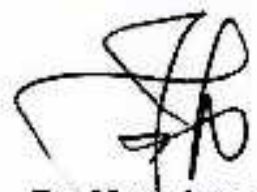

Dr. Mary Ismowati, M.Si

Pembimbing 